
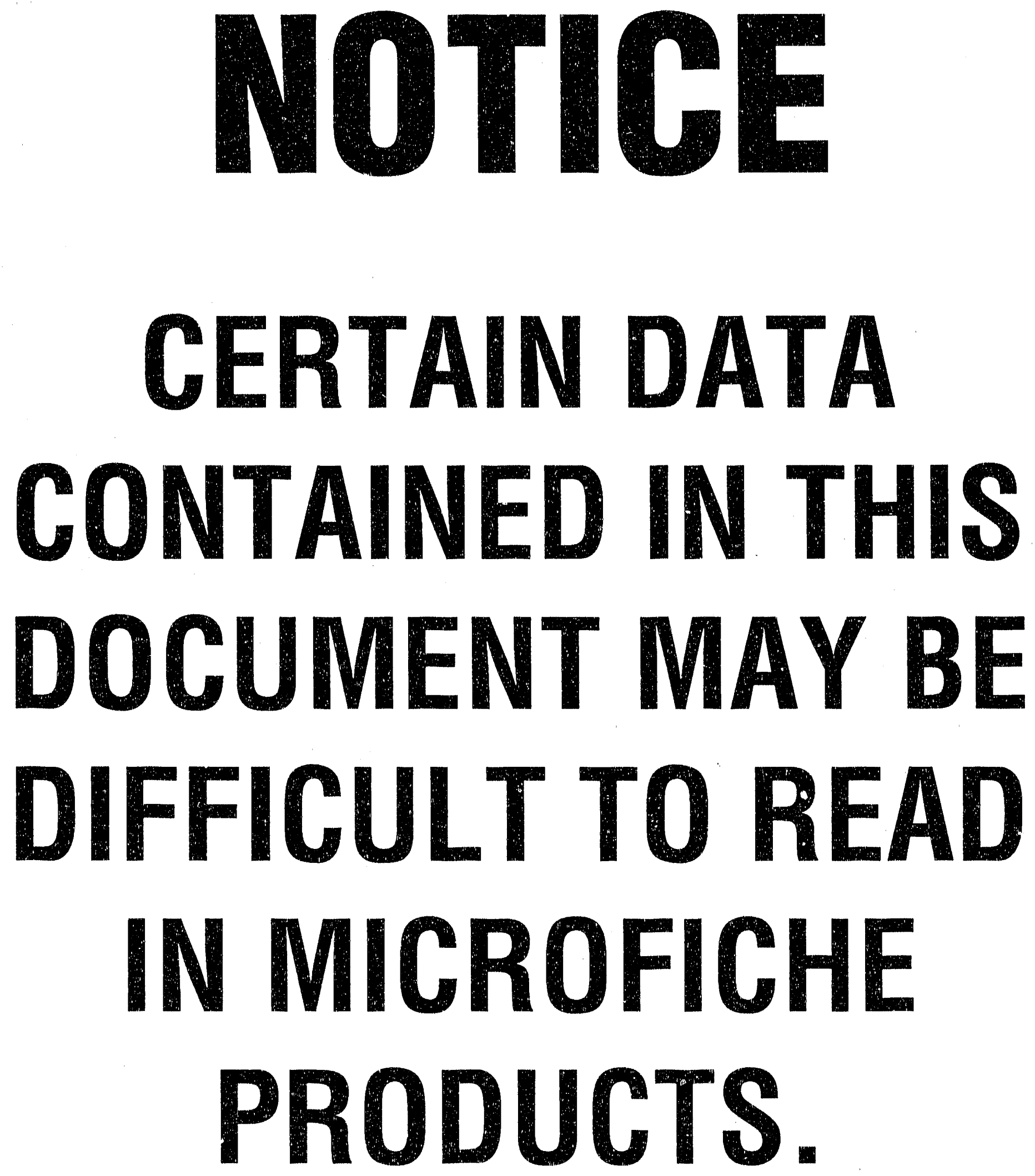


\section{ASSESSMENT OF TREE TOXICITY NEAR THE} F- AND H-AREA SEEPAGE BASINS OF THE SAVANNAH RIVER SITE (U)

Kathleen Parker Greenwood, Duke University

Matthew E. Hane, Duke University

April J. Lander, Duke University

Craig Loehle (editor), Environmental Sciences Section

Curtis J. Richardson (editor), Duke University

Approved by: DQReneree

D. B. Moore, Section Manager

Environmental Sciences Section

\section{DISCLAIMER}

This report was prepared as an account of work sponsored by an agency of the United States Government. Neither the United States Government nor any agency thereof, nor any of their employees, makes any warranty, express or implied, or assumes any legal liability or responsibility for the accuracy, completeness, or usefulness of any information, apparatus, product, or process disclosed, or represents that its use would not infringe privately owned rights. Reference herein to any specific commercial product, process, or service by trade name, trademark, manufacturer, or otherwise does not necessarily constitute or imply its endorsement, recommendation, or favoring by the United States Government or any agency thereof. The views and opinions of authors expressed herein do not necessarily state or reflect those of the United States Government or any agency thereof.

\section{WESTINGHOUSE SAVANNAH RIVER COMPANY \\ SAVANNAH RIVER SITE \\ AIKEN, SC 29808}


Required with all document recond copies ant to SSD/ISD

RECORD INDEXING

Call 5.2494 for assistance as needed.

Incomplete or incorrect forms will be relurned to originalor with record for review and correction.

Technical documents may also require OSR 14-357 Approval Sheet

PRINT or TYPE IN BLACK INK

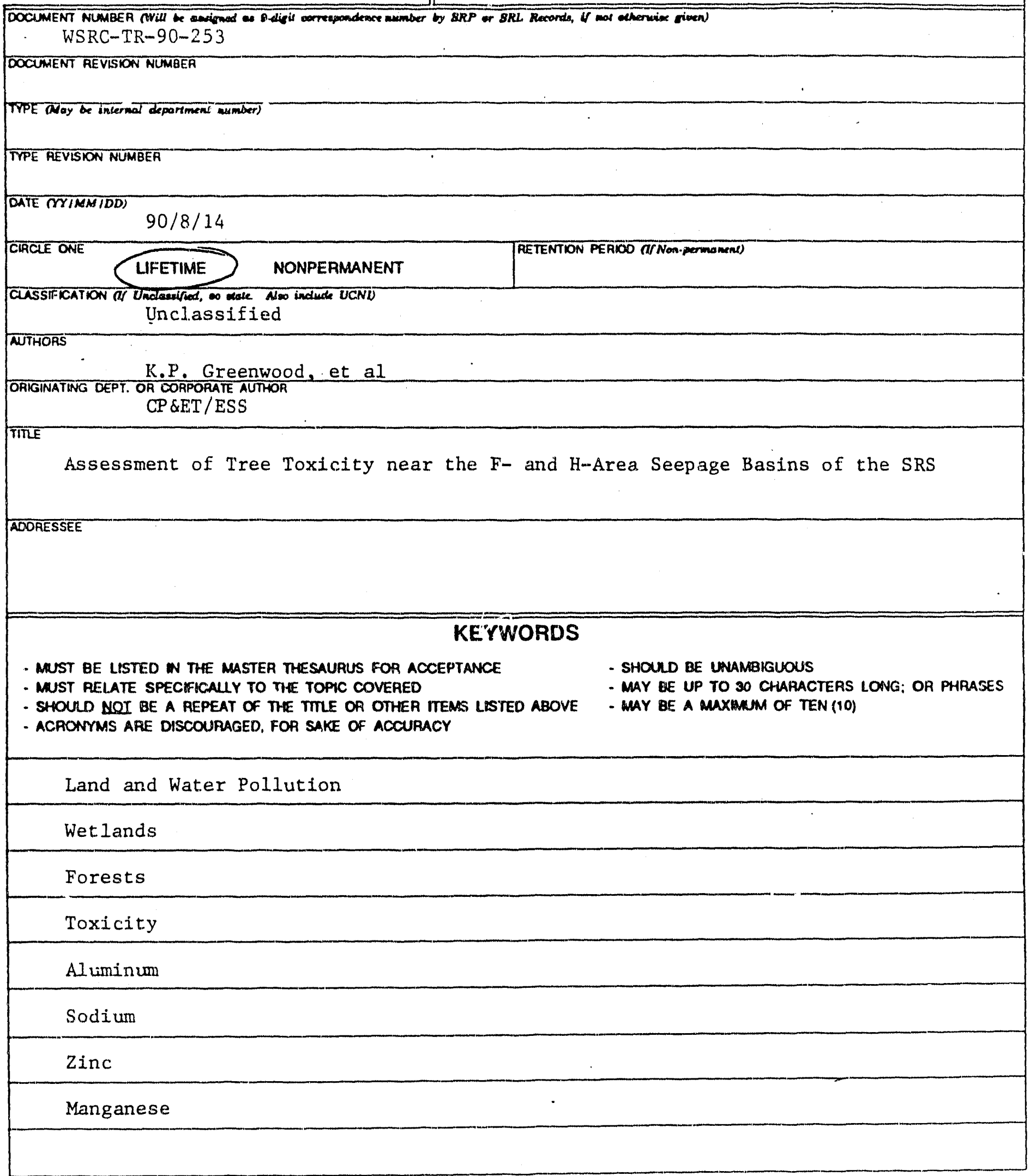


TABLE OF CONTENTS

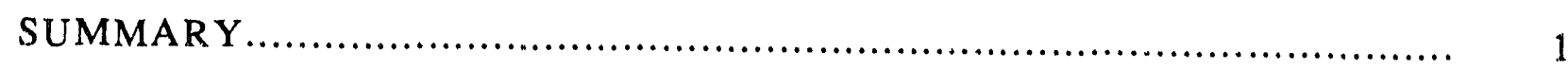

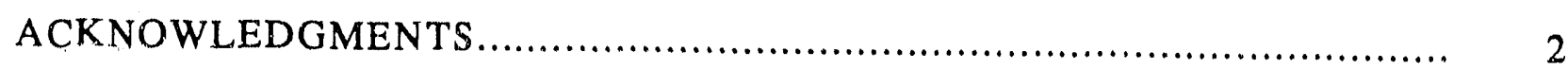

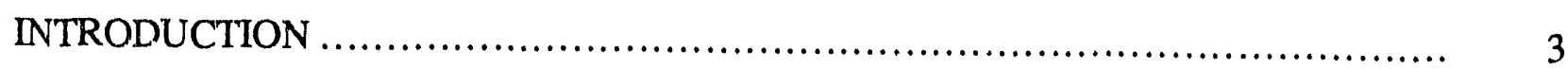

Description of the Impacted Sites _..................................................... 3

Methods of Analysis.............................................................. 4

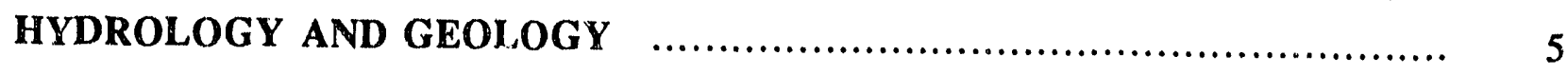

INTRODUCTION AND SITE DESCRIPTION ................................. 5

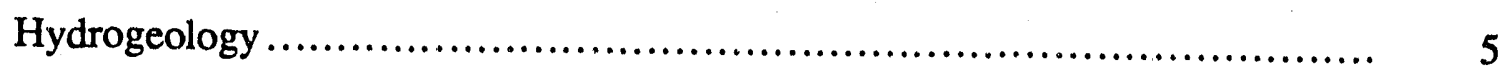

Precipitation............................................................. 9

RESPONSE OF VEGETATION TO ALTERED HYDROLOGY .................... 17

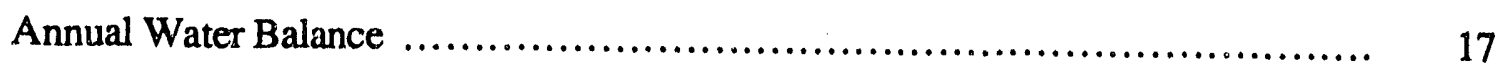

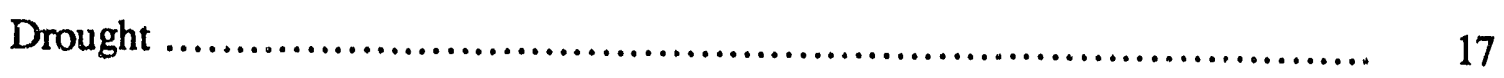

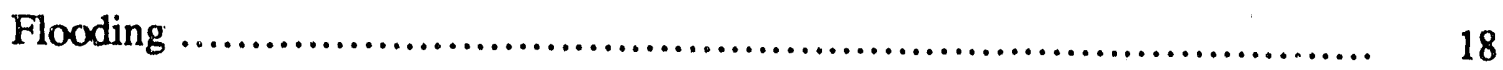

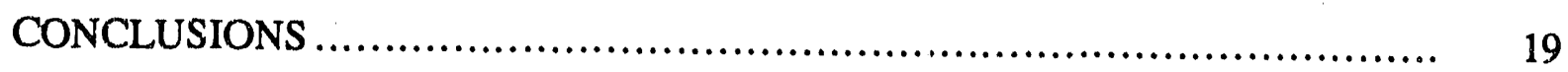

SOIL AND WATER CIIEMICAL PARAMETERS................................. 20

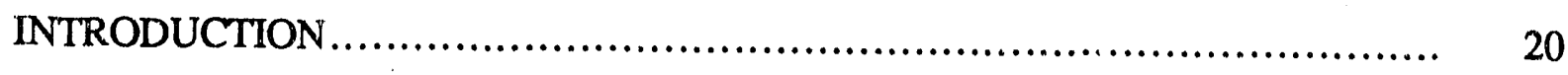

Available Data ....................................................... 20

Literature Review ..................................................... 20

Synthesis............................................................. 20

GROUNDWATER AND SOIL CHEMISTRY ................................ 21

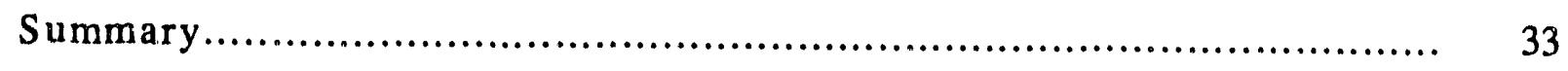

SOIL CHEMISTRY AND ITS INFLUENCE ON ION MOVEMENT .......... 34

Soil Types in the Affected Areas................................................. 34

Affects of Flooding on Soils ....................................................... 36 


\section{A REVIEW OF FACTORS RELATING TO THE DISTRIBUTION, TRANSPORT, AND BIOAVAILABILITY OF SELECTED

Sodium 38

Nitrate.

Manganese

Cadmium 40

Copper .

Chromium 40

Chromium (III). 40

Chromium (VI)

Affects on Soil

Mercury

Affects on Chlorides

Affect of Organic Matter

Biological Effects .

SOIL CHEMISTRY SYNTHESIS

CHEMICAL TOXICITY TO NYSSA SYLYATICA VAR. BIFLORA ........... 42

INTRODUCTION.

METHODS

SUMMARY OF LITERATURE FINDINGS.

Aluminum

Direct Toxicity.

Indirect Affects of Aluminum

Nitrate . 


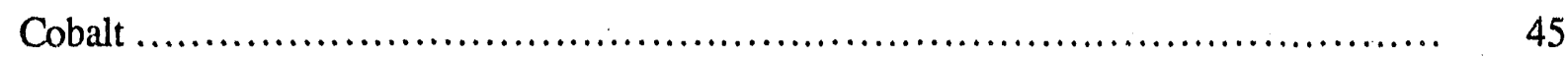

Phosphorus............................................................ 45

Sodium and Chloride....................................................... 45

Sulfate ................................................................. 47

Copper ................................................................. 48

Lead ...................................................................... 48

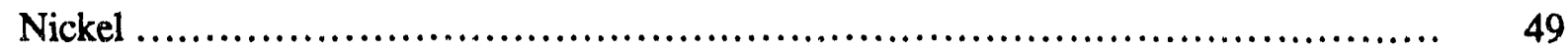

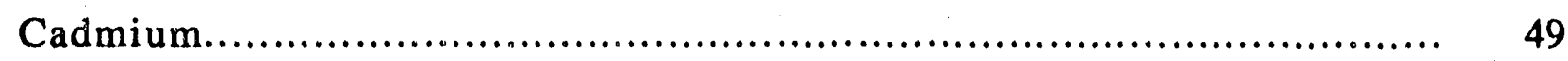

Zinc........................................................................... 50

COMPARISON OF LITERATURE DATA TO OUR DATA .............................. 52

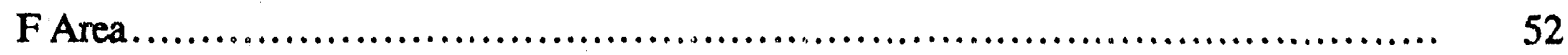

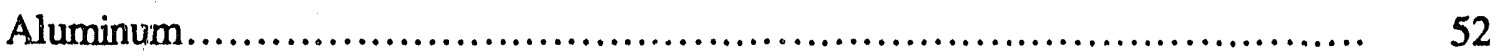

Nitrate .............................................................. 56

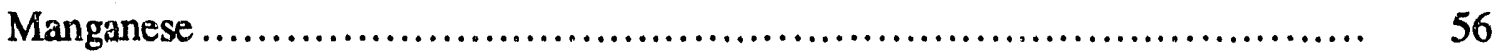

Sodium ............................................................... 56

Chloride ................................................................. 56

Sulfate .............................................................. 56

Copper, Lead, and Nickel........................................................ 56

Cadmium............................................................ 57

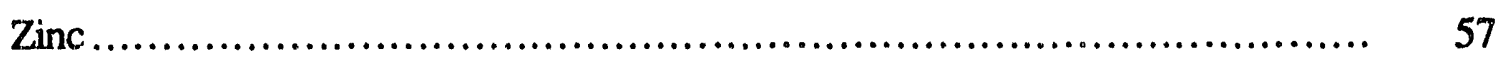

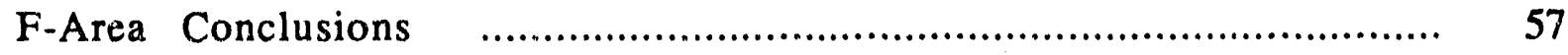

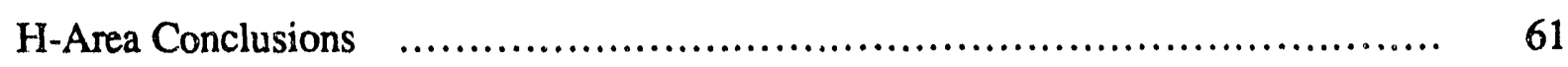

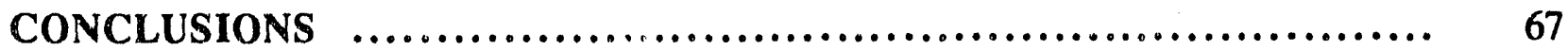

FINAL CONCLUSIONS $\ldots \ldots \ldots \ldots \ldots \ldots \ldots \ldots \ldots \ldots \ldots \ldots \ldots \ldots \ldots \ldots \ldots \ldots \ldots \ldots$

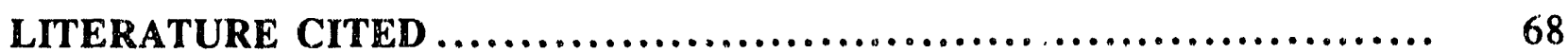

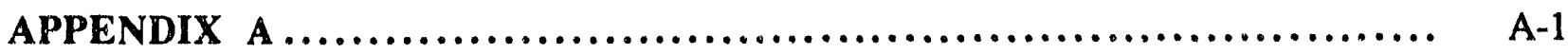




\section{List of Tables}

1. Monthly precipitation data for the Savannah River Site ........................... 13

2. Summary of deviations from mean monthly precipitation at the Savannah River Site ......................................................... 16

3. Soil types found in affected areas............................................. 35

4. Soil characteristics of a Wagram sandy loam, order Ultisol .......................... 36

5. Oxidized and reduced forms of major electron acceptors ............................ 37

6. Traditional classification of salt affected soils ..................................... 38

7. Comparison of literature data with F-Area data .................................. 53

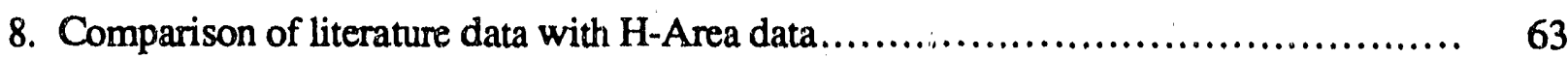




\section{List of Figures}

1. Sites of forest mortality and stress........................................... 4

2. Summary of the hydrogeologic system of the separations area ....................... 6

3. Upstream and downstream segments of Four Mile Creek ........................... 9

4. Ratio of discharge per unit area to precipitation .................................. 10

5. Annual precipitation data for the Savannah River Site................................... 11

6. Standard deviation from the mean annual precipitation................................. $\quad 12$

7. Standard deviation from mean growing season precipitation......................... 14

8. Mean monthly precipitation data ............................................. 15

9. Thorthwaite water budget................................................... 17

10. Sodium in groundwater, soil water, and soil cores.............................. 22

11. Nitrate in groundwater and surface water..................................... 23

12. Aluminum in groundwater, soil water, and soil cores.................................. 24

13. Specific conductivity in groundwater ......................................... 25

14. Manganese in groundwater, soil water, and soil cores........................... 26

15. Chromium in groundwater, soil water, and soil cores ............................ 27

16. Copper in groundwater, soil water, and soil cores ............................... 28

17. Nickel in groundwater, soil water, and soil cores ................................ 29

18. Comparison of $\mathrm{NH}_{4} \mathrm{Cl}$ and oxalate extraction procedures for aluminum ............. 30

19. Major cations in soils....................................................... 31

20. Speciation diagram for iron and manganese ..................................... 37

21. Comparison of aluminum literature solution data with F-Area seep line data............. 58

22. Comparison of zinc and cadmium literature solution data with F-Area seep line data ... 58

23. Comparison of aluminum literature leaf data with F-Area leaf data................... 59

24. Comparison of manganese literature leaf data with F-Area leaf data ................... 59

25. Comparison of aluminum literature root data with F-Area root data.................. 60

26. Comparison of manganese literature root data with F-Area root data ................ 60

27. Comparison of aluminum literature leaf data with $\mathrm{H}$-Area leaf data ..................... 62

28. Comparison of aluminum literature root data with H-Area root data .................... 62 
WSRC-TR-90-253

\title{
ASSESSMENT OF TREE TOXICITY NEAR THE F-AND H-AREA SEEPAGE BASINS OF THE SAVANNAH RIVER SITE
}

\author{
by \\ K.P. Greenwood, M.E. Hane, A.J. Lander, and \\ C.J. Richardson (Editor) \\ Duke University \\ Durham, North Carolina 27706 \\ Craig Loehle (Editor) \\ Westinghouse Savannah River Company \\ Savannah River Site \\ Aiken, South Carolina 29808
}

\begin{abstract}
SUMMARY
Areas of tree mortality, originating in 1979 , have been documented downslope of the F- and $\mathrm{H}$-Area Seepage Basins. The basins were used as discharge areas for low-level radioactive and nonradioactive waste. The species suffering the most damage was Nyssa sylvatica var. biflora. The cause of mortality is thought to be directly related to the movement of wastes from the seepage basins through the ground and outcropping in the wetland areas.

Preliminary studies indicated that there are three possible causes of stress: altered hydrology; hazardous chemicals; and nonhazardous chemicals. However, these studies did not correlate the relationship between the observed vegetational affects and altered hydrology or elevated chemical concentrations. This study was undertaken to identify these relationships.

It was originally hypothesized that the most likely hydrological stressors to Nyssa svlvatica var. biflora were flooding where water levels cover the lenticels for more than 26 percent of the growing season, resulting in low oxygen availability, and toxins produced under anaerobic conditions. Because of inputs of water from the seepage basins, flooding could have occurred, but. no evidence for flooding could be documented. In fact, trees began to show stress only following a drought year (1977) rather than a wet year. Dry conditions could exacerbate stress by concentrating contaminants, particularly salt.

Study of the soil and water chemical parameters in the impacted sites indicated that salt concentrations in the affected areas have produced abnormally high exchangeable sodium percentages. Furthermore, significantly elevated concentrations of heavy metals were found in each impacted site, although no one metal was consistently elevated. This condition may have led to direct toxicity by a different factor in each area or the heavy metals may have acted is an intermediary for other agents, such as manganese toxicity.

Evaluation of the concentrations of various chemicals toxic to Nyssa sylvatica var. biflora revealed that aluminum was probably the most toxic in the F-Area. Manganese, cadmium, and zinc had concentrations great enough to be considered possible causes of tree mortality in the F-Area. Aluminum was the most likely cause of mortality in the H-Area. Sodium was very high in both areas but plant resporses to sodium are highly variable, so it is difficult to evaluate the role of sodium given the available information. Controlled experiments testing metal and salt concentration effects on Nyssa sylvatica would be needed to specifically assign cause and effect mortality relationships.
\end{abstract}




\section{ACKNOWLEDGMENTS}

This report as prepared in part by the Duke University Wetland Center, School of Forestry and Environmental Studies, for the Westinghouse Savannah River Company under Subcontract No. 272080.

The research on tree toxicology, hydrology, and soil and water chemistry was conducted by Kathleen Parker Groenwood, Matthew E. Hane, and April J. Lander under the supervision of Dr. Curtis J. Richardson. Additional data were supplied by Dr. Craig Loehle, MetaTRACE, Exploration Research, and Thermoanalytic Laboratories.

The study was under the general supervision and editing of Dr. Craig Loehle of the Environmental Sciences Division of the Westinghouse Savannah River Company.

Thanks to Paul Bertsch, Carl Strojan, Ken McLeod, and Tony Towns of the Savannah River Ecology Lab for field assistance. John Haselow, John Gladden, Paul Bertsch, Lynn Wike, Brian Looney, and Chas Murphy provided helpful reviews of all or part of the manuscript. 


\section{INTRODUCTION}

The Savannah River Site in Aiken, South Carolina began discharging effluents to the F- and H-Area Seepage Basins with lowlevel and nonradioactive liquid waste in 1955 (Killian et al., 1987a, b). The purpose of the basins was to delay the release of tritium to surface streams and detain other radionuclides (Killian et al, 1987a and 1987b). Since approximately 1979, tree mortality has occurred (Mackey, 1988) in several areas downslope of the $\mathrm{F}$ - and $\mathrm{H}$ Area Seepage Basins (Figure 1). Of all the species on these sites, Nyssa sylvatica var. biflora was the most severely impacted (Loehle and Gladden, 1988). The exact cause of mortality must be known in order to take remediation measures. This report assesses the potential causes of tree mortality.

Several preliminary studies indicated possible explanations for the tree kill. Looney, et al. (1988) analyzed several upstream and downstream water samples and identified several parameters that have been altered by activities in the $\mathrm{F}$ - and $\mathrm{H}$-Areas. In the F-Area, conductivity, total dissolved solids, and sodium concentrations were significantly higher near the affected sites; while in the H-Area, conductivity, total dissolved solids, nitrate, phosphate, sodium, and potassium wore significantly higher. Thus, the study concluded that effluent from the seepage basins has significantly contributed to the observed concentration increases in the affected wetlands along the seepline near Four Mile Creek.

A study by Loehle and Gladden (1988) characterized three classes of poiential stressors:

- Alterations in site hydrology

- Chemical stress resulting from hazardous materials

- Chemical stress resulting from nonhazardous materials

The previous studies did not define the relationships between elevated chemical concentrations and the observed vegetational effects. Information dealing with vegetation tolerance to levels of specific ions is necessary to determine the dominant factors negatively affecting the terrestrial/wetland environment in the impacted areas.

\section{Description of the Impacted Sites}

Tree mortality was found in both the F- and $\mathrm{H}$-Areas (Figure 1). Two sites were found in the F-Area with one having tree mortality (FImpacted) and the other showing signs of stress (F-Intermediate). The H-Area site also had tree mortality. The sites were located between the F- and H-Area Seepage Basins and Four Mile Creek. All sites had pure stands of swamp tupelo (Nyssa sylyatica var. biflora ) growing on them. A control site was located upstream on Four Mile Creek (Figure 1) at which soil and vegetation samples were taken for comparison.

Killian et al. (1987a and 1987b) summarized the disposal history for F-and $\mathrm{H}$ Areas. This information is useful in determining possible sources of contamination. The seepage basins were routinely used to receive wastewater containing low-level radioactivity and chemicals from separation facilities. The soil column and groundwater pathways to surface outcrops were used to delay the release of tritium to surface streams and effectively detain other radionuclides.

E-Area. The primary sources of effluents are nitric acid recovery units and several other types of chemical evaporators. Cumulative release of mercury between 1955 and 1970 was $380 \mathrm{~kg}$. Mercury was used as an aid in dissolving aluminum alloy fuels. Sodium hydroxide released into the basin also contained trace amounts of mercury, however the amount has not been quantified. Releases of sodium hydroxide averaged $90,700 \mathrm{~kg}$ per year. It was used to neutralize high-level radicactive wastes prior to storage. Releases of nitrate averaged $234,300 \mathrm{~kg}$ per year. Values of pH ranged from 1.52 to 12.8 with an average of 2.93. Sodium concentration ranged from 110 to $1900 \mathrm{mg} / \mathrm{L}$ 1 with an average of $790 \mathrm{mg} / \mathrm{L}^{-1}$.

$\boldsymbol{H}$-Area. The primary sources of effluents were nitric acid recovery units, several types 
of chemical evaporators, and cossling waters for tritium production facilities. Cumulative release of mercury between 1955 and 1970 was $1630 \mathrm{~kg}$. Average release of $\mathrm{NaOH}$ was $90,800 \mathrm{~kg}$ per year. Sodium hydroxide was used in a resin regeneration process. Average release of $\mathrm{H}_{3} \mathrm{PO}_{4}$ and $\mathrm{Na}_{2} \mathrm{Cr}_{2} \mathrm{O}_{7}$ was 5540 and $544 \mathrm{~kg}$ per year, respectively. Both are used as Li-Al target cleaners.

Values of $\mathrm{pH}$ ranged from 1.96 to 5.48 with an average of 2.37. Sodium ranged from 6.1 to $61.6 \mathrm{mg} / \mathrm{L}^{-1}$ with an average $17.6 \mathrm{mg} / \mathrm{L}^{-1}$.

\section{Methods of Analysis}

Research was divided into three projects and conducted in two phases. The first project assessed vegetation stress due to changes in site hydrology; the second evaluated soil and water chemical parameters, including baseline studies and determination of probable surface and groundwater transport mechanisms; and the third identified chemical stressors which were toxic to Nyssa sylvatica var. biflora.

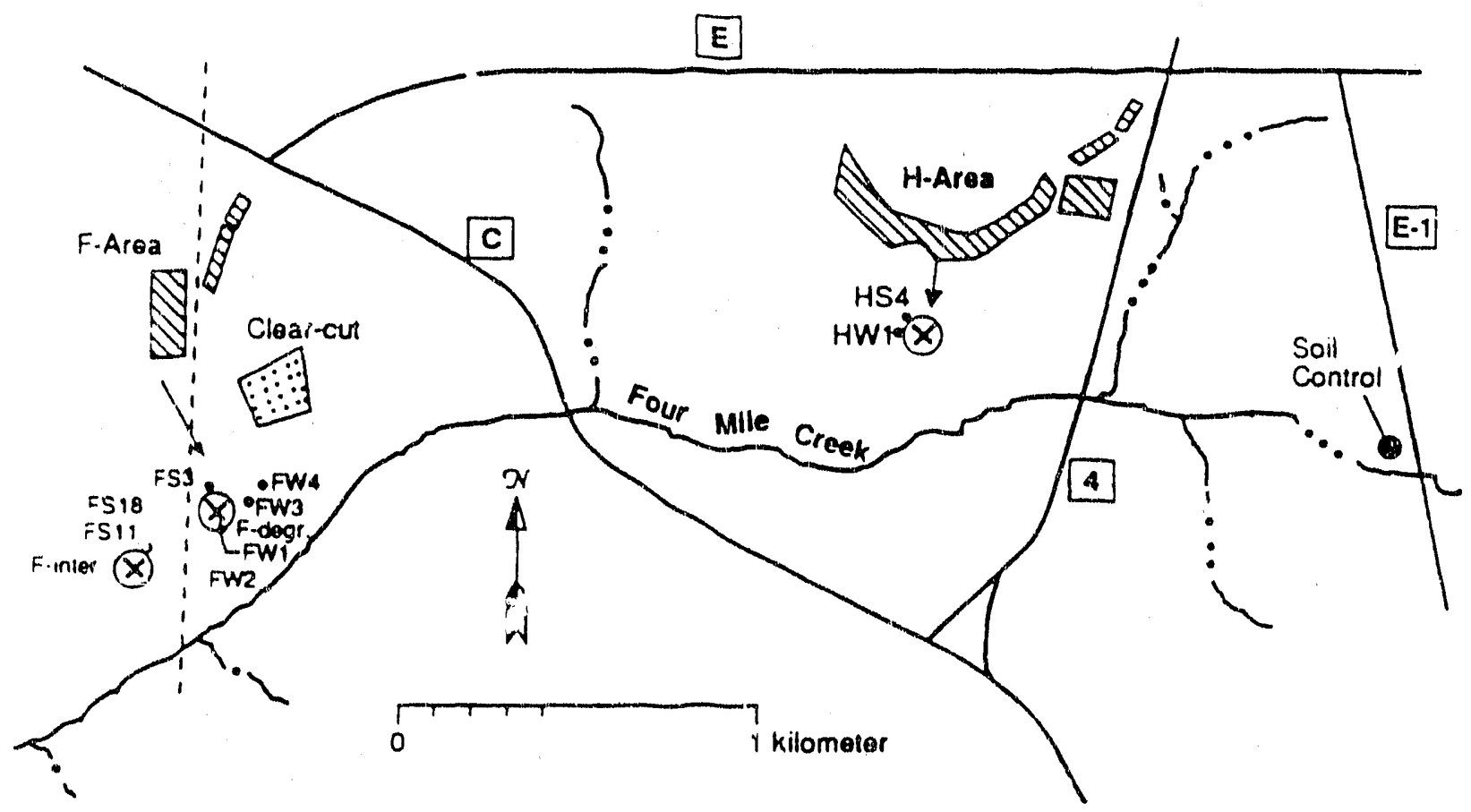

Figure 1. Map of study site.Cross-hatched areas are seepage toasins, " $\mathrm{X}$ " indicates sceps with forest dieback, the filled circle indicates location of control soil samples, and letters/numbers in boxes are road designations. The elevation of seepage basins is c3. $15.20 \mathrm{~m}$ above Four Mile Creek. Dark arrows indicate direction of slope.Other designations (eg., HS4) are soil and water chemistry sample identifiers, discussed in following sections. 
During the first phase information concerning site hydrology, chemical transformations of possible stressors, and assessment of toxicity levels of chemical elements which may have affected Nyssa sylvatica var. biflora was integrated in order to narrow the list of candidate stressors. In order to obtain this information, a computerized liierature search was conducted using the BRS After Dark Database system. During Phase II, the data gathered from phase one was analyzed in an attempt to correlate the candidate stressors with the tree mortality.

\section{HYDROLOGY AND GEOLOGY}

\section{INTRODUCTION AND SITE DESCRIPTION}

The objective of this section is to determine the importance of hydrologic stress by defining the relationships between hydrologic alterations and the observed effects on the damaged and stressed vegetation.

Research was conducted in two phases. During the first phase, information was gathered in order to assess the hydrolog of the stressed sites and to evaluate the effects of altered hydrology on Nyssa sylvatica var. biflora. Specifically, the geology, hydrologic history of the impacted areas, the physiological and morphological responses of Nyssa sylvatica var. biflora to water table perturbations were assessed.

During the second phase, the information gathered during Phase I was analyzed in an attempt to correlate changes in hydrology with tree mortality. Precipitation data was statistically analyzed for abnormally high or low values, and water budget data was analyzed to determine if unusually high rates of evapotranspiration occurred during the time of tree mortality.

\section{Hydrogeology.}

The Savannah River Site is located in the Aiken Plateau and Congaree Sand Hills of the Atlantic Coastal Plain. The study site, ranging from the $\mathrm{F}$ - and $\mathrm{H}$-Area Seepage Basins to Four Mile Creek, is exclusively found in the Aiken Plateau. According to Siple (1967) the surface of the plateau is highly dissected, has broad interfluvial regions, and relatively narrow and steep valleys which have been cut up to 90 meters
(300 feet). The inte fluvial regions are found on gently sloping upland plains and are generally well drained, although poorly drained solution sinks and Carolina Bays are fairly common in areas above calcareous beds. In the tuldy region no Carolina Bays are present, but solution sir'ss zre a possibility.

The following information is taken from GeoTrans (1988) as modified by Haselow The hydrogeologic system consists of nine important hydrostratigraphic units. These units include (in descending order) the Barnwell, McBean, Congaree, and upper and lower Cretaceous aquifers, separated by the Tan Clay, Green Clay, Ellenton Clay, and middle Cretaceous Clay confining units, respectively. The factors governing groundwater flow at the General Separations Area are: (1) seepage basin influx to the groundwater flow sysiem, (2) the nearest surface water boundaries, Four Mile Creek and Upper Three Runs Creek, (3) the wetlands near Four Mile Creek, (4) lateral groundwater flow into and out of the local region, (5) vertical leakage, and (6) precipitation recha-ge. Figure 2 surnmarizes the hydrogeologic system of the area.

The Barnwell aquifer can be separated into two distinct units by textural characteristics. The upper part of the Barnwell aquifer is mostly clayey sand with discontinuous clay and silt lenses; in the lower part, silty and poorly-graded sand predominates. The Tan Clay formation separates the Barnwell and McBean aquifers. The Tan Clay unit ranges from 0 to more than 10 feet in thickness, averaging 3 to 5 feet. This clay is thickest and almost continuous under $\mathrm{H}$-Area. Although the clay is a discontinuous layer, it appears to have 
sonfining effects extensively over the study area and is conceptually a continuous unit.

The MoBean aquifer also exhibits vertical textural trends. The uppor part of the unit is mostly clayey and poorly-graded sand, while the lower part is predominantly clayey and silty sand; clay and silt lenses are distributed throughout the full thickness of sne McBean aquifer. Some portions of the McBean aquifer also exhibit calcareous zones. The McBean and Congaree aquifers are separated by the Green Clay confining unit. Although some portions of this unit are discontinuous, insufficient information exists to discretize these discontinuous areas. Thus, the Green Clay may be considered a continuous confining unit. The observed thickness ranges from 0 to $20 \mathrm{feet}$, but averages between 3 to 6 feet. The Congaree aquifer is composed of a coarsening upward

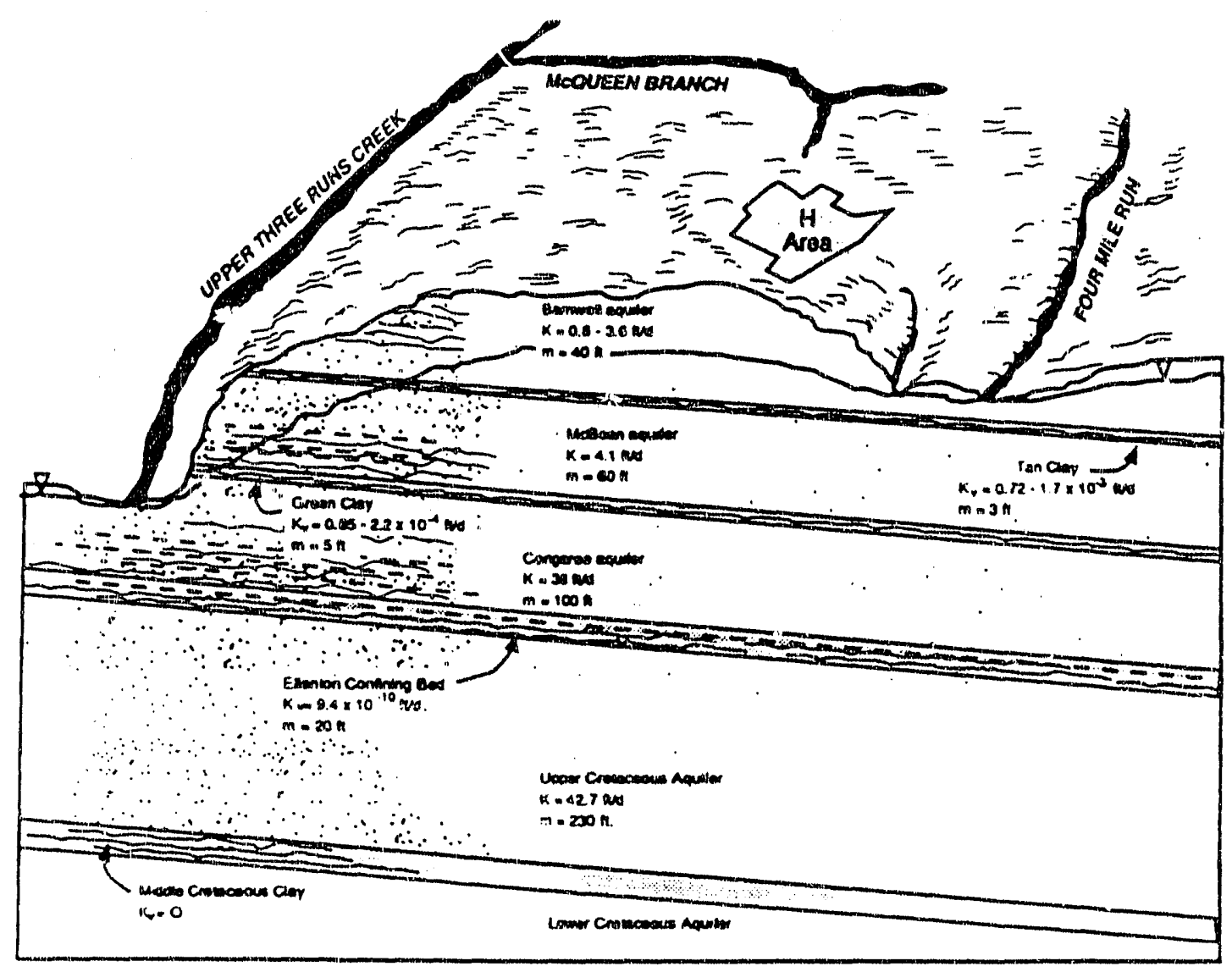

Figure 2. Summary of the hydrogeological system of the Separations Area. 
sequence of clays, silts, and sands. The upper part of the unit consists of poorlysorted sand. The lower part consists of primarily fine-grained materials such as clayey and silty sand. The Congaree aquifer is underlain by the Ellenton confining unit, a very compact clay and silt sequence approximately 175 feet in thickness. This confining unit restricts flow between the Congaree and upper Tuscaloosa aquifers.

The upper Cretaceous aquifer consists of cross-bedded quartzose sanc and gravel interbedded with lenses of clay and silt. The upper Cretaceous is about 180-feet thick in the study area. The upper Cretaceous and lower Cretaceous aquifers are separated by the middle Cretaceous Clay, also known as the Middle Clay. 'The Middle Clay confining layer consists of an approximately 140-feet thick clay, silt, and sand sequence. The lower Cretaceous aquifer is 110 -feet thick in the study area and consists of cross-bedded sand and gravel with minor amounts of clay and silt. The lower Cretaceous is underlain by a basal variegated clay and saprolite unit. The lower and upper Cretaceous formation serve as major sources of water for SRS and the region.

These units are integrated into a multiaquifer groundwater flow system that exhibits vertical interconnection. The flow paths are characterized by complex horizontal and vertical directions. Large scale aquifer flow directions are influenced by the following: (1) structural attitude of the aquifers, (2) topographic relief and outcrop pattern, (3) lithologic character (hydraulic conductivity distribution) of the unit, and (4) elevation of bounding streams. Within the area, the multi-aquifer system has three important factors in relation to hydraulic head distributions: (1) the local reversal of vertical leakage between the Congaree and Cretaceous aquifer units in the vicinity of the pumping wells, (2) multidirectional horizontal flow paths in all five aquifers, and (3) strong downward vertical gradients in the Barnwell and $\mathrm{McB}$ ean aquifers, especially in the area of elevated topography near the central part of the General Separations Area. These features are important in assessing groundwater flow characteristics within the study area.

Two important features within this multiaquifer system control the flow direction and magnitude of hydraulic head: (1) the elevation of Upper Three Runs Creek, and (2) the location of the groundwater divide in the water-table (Barnwell) aquifer. Upper Three Runs Creek acts as a regional discharge area for the Congaree aquifer. This is the result of vertical gradients in the Barnwell and McBean aquifers. Due to vertical gradients, a regional sink for groundwater flow is created in these upper three aquifers. Thus, vertical leakage and contaminants from Barnwell and McBean aquifers that reach the Congaree will flow toward Upper Three Runs Creek. Horizontal flow in the Barnwell and McBean formations is controlled by a groundwater divide in each formation. This groundwater divide separates horizontal flow toward Upper Three Runs Creek from flow toward Four Mile Creek.

The water table occurs primarily in the lower Barnwell. The water table slopes laterally away from an east-west trending groundwater divide toward Upper Three Runs Creek and Four Mile Creek. As a result, the saturated thickness of the Barnwell varies from 0 to 80 feet, averaging 40 feet. Based on aquifer tests, the hydraulic conductivity of the formation ranges from 0.06 to $85 \mathrm{ft} / \mathrm{d}$. The average transmissivity is about $40 \mathrm{ft} 2 / \mathrm{d}$. Assuming a horizontal-tovertical hydraulic conductivity ratio of $100: 1$, the vertical hydraulic conductivity is 0.01 $\mathrm{ft} / \mathrm{d}$.

Near Upper Three Runs Creek, the McBean aquifer becomes unsaturated as the water table exists in the underlying Congaree. Therefore, the saturated thickness of the McBean aquifer in part of the study area approaches zero. Where the formation is fully saturated, its thickness is approximately 60 feet. The hydraulic conductivity of the formation is on the order of 0.1 to $1.0 \mathrm{ft} / \mathrm{d}$ (based on aquifer tests). Thus, the transmissivity ranges from 0 to $60 \mathrm{ft}^{2} / \mathrm{d}$. Assuming a horizontal-to-vertical conductivity ratio of $100: 1$, the vertical hydraulic conductivity is $0.01 \mathrm{ft} / \mathrm{d}$. 
Transmissivity determinations for the Congaree aquifer range from 500 to $7000 \mathrm{ft}$ $2 /$ d. Its saturated thickness is about 100 feet. The estimated horizontal-to-vertical conductivity ratio is $100: 1$; therefore, vertical conductivity is estimated to be in the range of 0.05 to $1.0 \mathrm{ft} / \mathrm{d}$.

Reported transmissivity values for the combined upper and lower cretaceous aquifers range from 10,000 to $26,000 \mathrm{ft} 2 / \mathrm{d}$. Estimates for the individual upper and lower Tuscaloosa aquifer transmissivities range from 4000 to $10,000 \mathrm{ft}^{2} / \mathrm{d}$ and 6000 to $16,000 \mathrm{ft} 2 / \mathrm{d}$, respectively. The saturated thickness of the upper Cretaceous aquifer is 180 feet; the saturated thickness of the lower Cretaceous aquifer is 110 feet. Assuming a horizontal-to-vertical conductivity ratio of $10: 1$, the vertical hydraulic conductivity of the upper Cretaceous may be on the order of 2 to $6 \mathrm{ft} / \mathrm{d}$.

Only very limited hydraulic testing has been performed on the confining units within the study area. The Tan Clay vertical hydraulic conductivity of $2 \times 10^{-3} \mathrm{ft} / \mathrm{d}$ is estimated from one measurement north of $\mathrm{H}$ Area. Vertical hydraulic conductivity measurements are not available for the Green Clay, the upper Ellenton Formation, or the middle Cretaceous Clay; the estimated average vertical hydraulic conductivities for the Green Clay, the Upper Ellenton and the middle Cretaceous Clay are $1.5 \times 10^{-4} \mathrm{ft} / \mathrm{d}$, $8.7 \times 10^{-9} \mathrm{ft} / \mathrm{d}$, and $6 \times 10^{-2} \mathrm{ft} / \mathrm{d}$, respectively.

Preferential pathways for groundwater flow, i.e., high-hydraulic conductivity zones, in the Barnwell aquifer, in the vicinity of the seepage basins, have been documented by several authors. Concentration plumes of nitrate and tritium in previously sampled wells show elongated patterns downgradient. This plume elongation suggests increased groundwater velocity associated with zones of higher hydraulic conductivity. Comparisons with high terrain conductivity values generally agree with the location of these zones.

\section{Surface Water and Groundwater}

According to (Looney, 1988) the primary sources of water for the impacted wetlands are the F- and H-Area Seepage Basins. Other sources are precipitation, groundwater, and (rarely) overflow from Four Mile Creek. Due to the lack of data, it is impossible at this time to determine what percentage of the total each source provides to the sites.

Groundwater flow originates from the Barnwell Formation and possibly the McBean and Hawthorn Formations. Figure 2 shows the Four Mile Creek valley and its association with these formations.

After the seepage basin groundwater input, the damaged wetlands probably receive most of their groundwater inputs from the Barnwell Formation. This formation has relatively low water supply rates and a relatively high ratio of discharge per unit area to precipitation. It is associated with flows which are seasonally variable since the formation is influenced by precipitation and evaporation processes due to the proximity of the aquifer to the earth's surface (Williams and Pinder, 1989). Inputs may also be received from the Hawthorn Formation which has similar characteristics to the Barnwell Formation, and from the McBean Formation which has higher water supply rates and a low output to input ratio, resulting in flows which do not vary greatly with season.

The impacted wetlands most likely have an input/output ratio which is similar to those found by Williams and Pinder (1989) for Four Mile Creek at the confluence with the H-Area Creek (station 34 on Figure 3) since this location is associated with the Barnwell aquifer. The winter ratio was 0.5 and the summer ratio was 0.1 , giving an annual average of 0.3 . Since the damaged site may be associated with the McBean Formation the actual ratio may be closer to 0.85 . Figure 4 shows the dynamics of the output to input ratios for stations 34 and 40. 
Overflow from Four Mile Creek may occur when precipitation is significantly high since the creek receives approximately 10 percent of its flow from surface runoff and interflow following precipitation.

Killian et $-i$. (1987a and 1987b) predicted 4 years as the minimum time-oftravel for tritium between the seepage basins and Four Mile Creek. Since the wetlands along the seepline are approximately halfway to Four Mile Creek, it can be estimated that the time-of-travel for tritium and other contaminants would be approximately two years.

\section{Precipitation}

Precipitation is also an important hydrological input to the swamp system adjacent to Four Mile Creek since water is added directly to the wetlands. Flooding by
Four Mile Creek caused by high precipitation may occasionally increase water levels in the wetlands.

Precipitation data from 1968 to 1988 were available. Table 1 shows the monthly precipitation data. The average annual rainfall was $126.8 \mathrm{~cm}$ (49.90 inches) with a standard deviation of $18.16 \mathrm{~cm}$ (7.15 inches) (Figure 5). Figure 6 shows the standard deviations from the mean for each year. Nineteen sixty-nine was the only year which was significantly less than normal at greater than two standard deviations from the mean, with $39.65 \mathrm{~cm}$ (15.61 inches). No tree stress occurred during this period of drought, suggesting that abnormally low precipitation by itself does not cause tree mortality or stress in damaged sites. However, it is possible that more severe drought effects may occur if inputs to the seepage basins or natural groundwater flows significantly

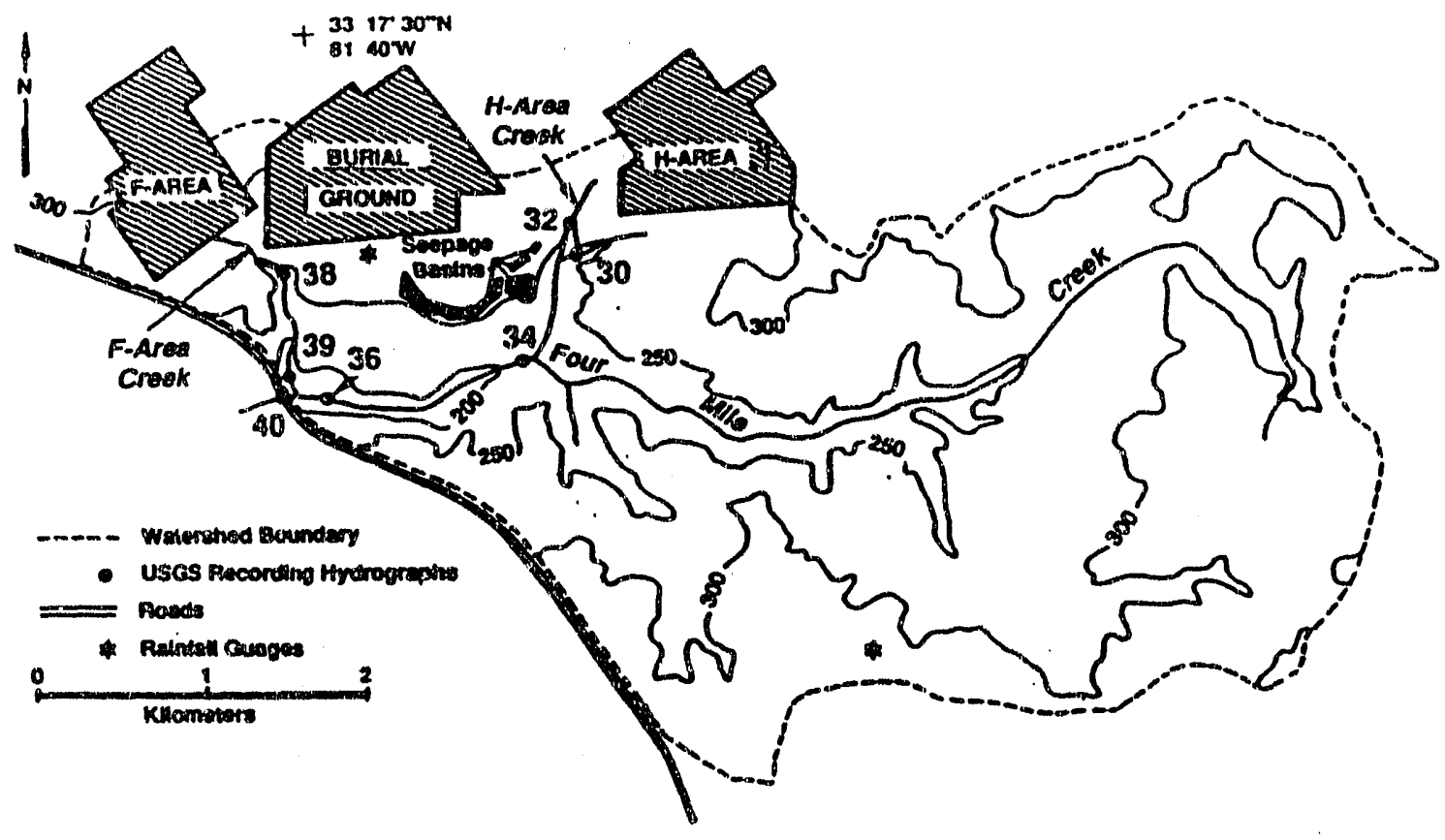

Figure 3. Upstream and downstream segments of Four Mile Creek (Williams and Pinder, 1989) 


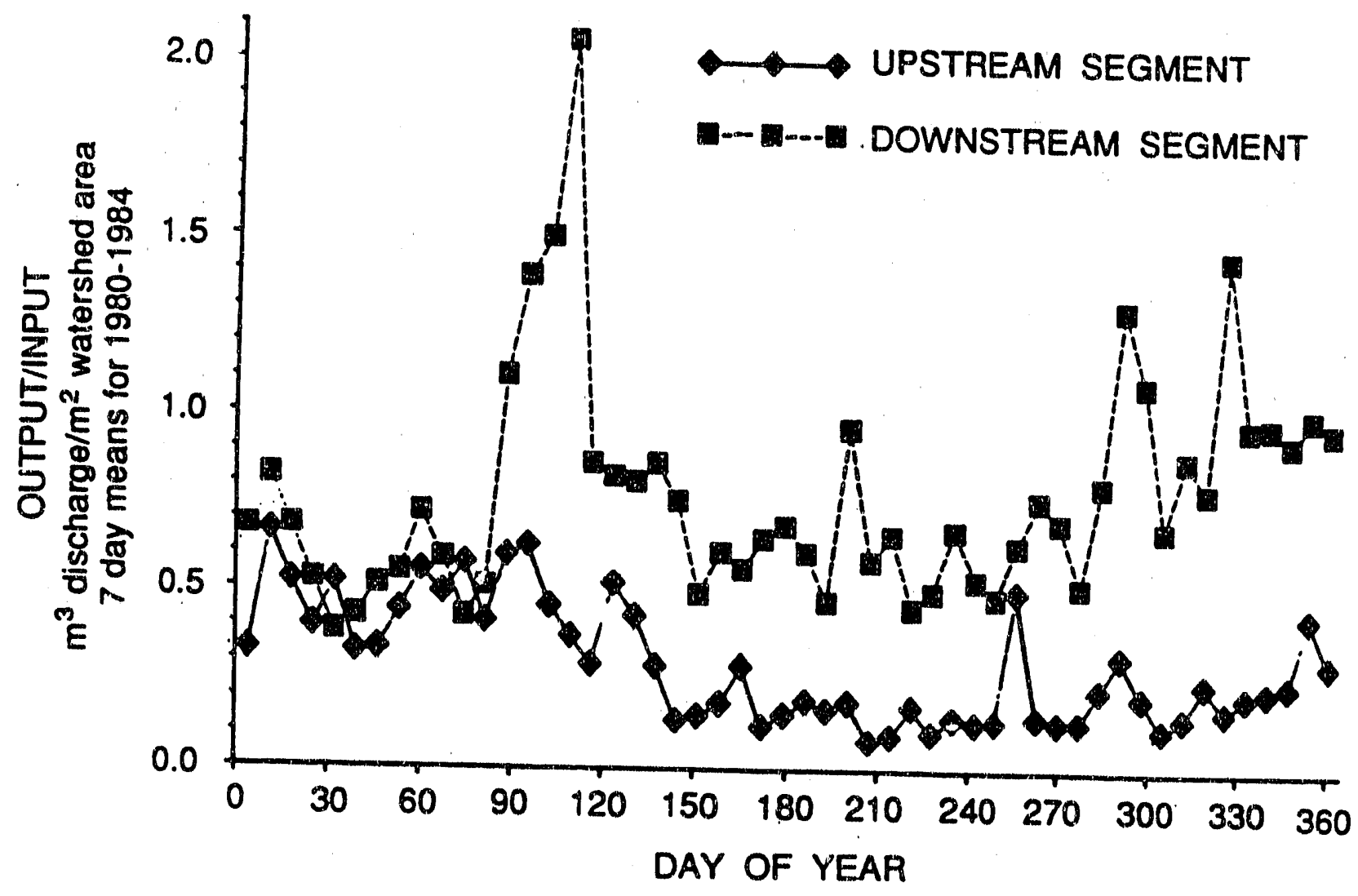

Figure 4. Ratio of discharge per unit area to precipitation (William and Pinder, 1989) 


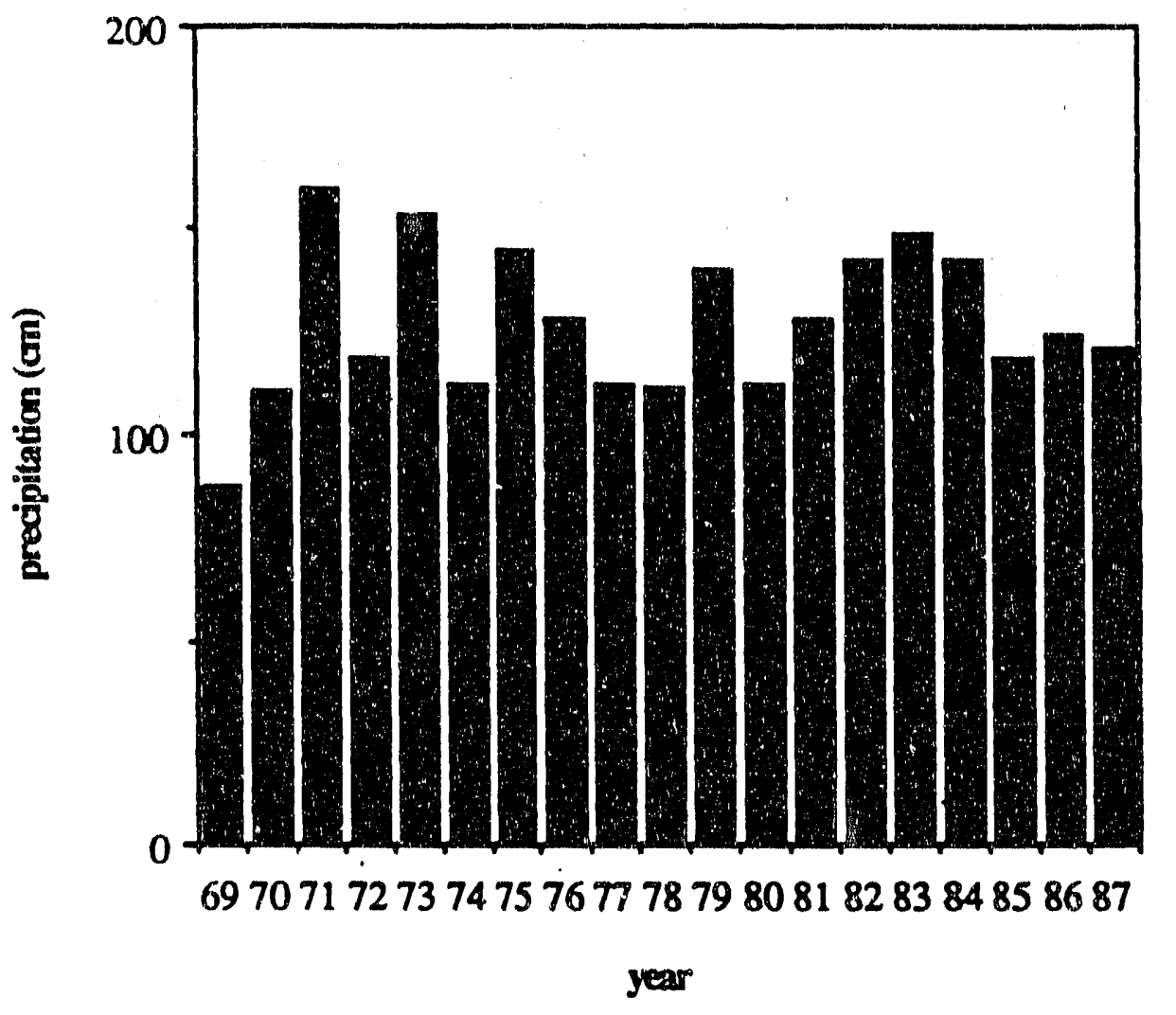

Figure 5. Annual precipitation data for the Savannah River Site 


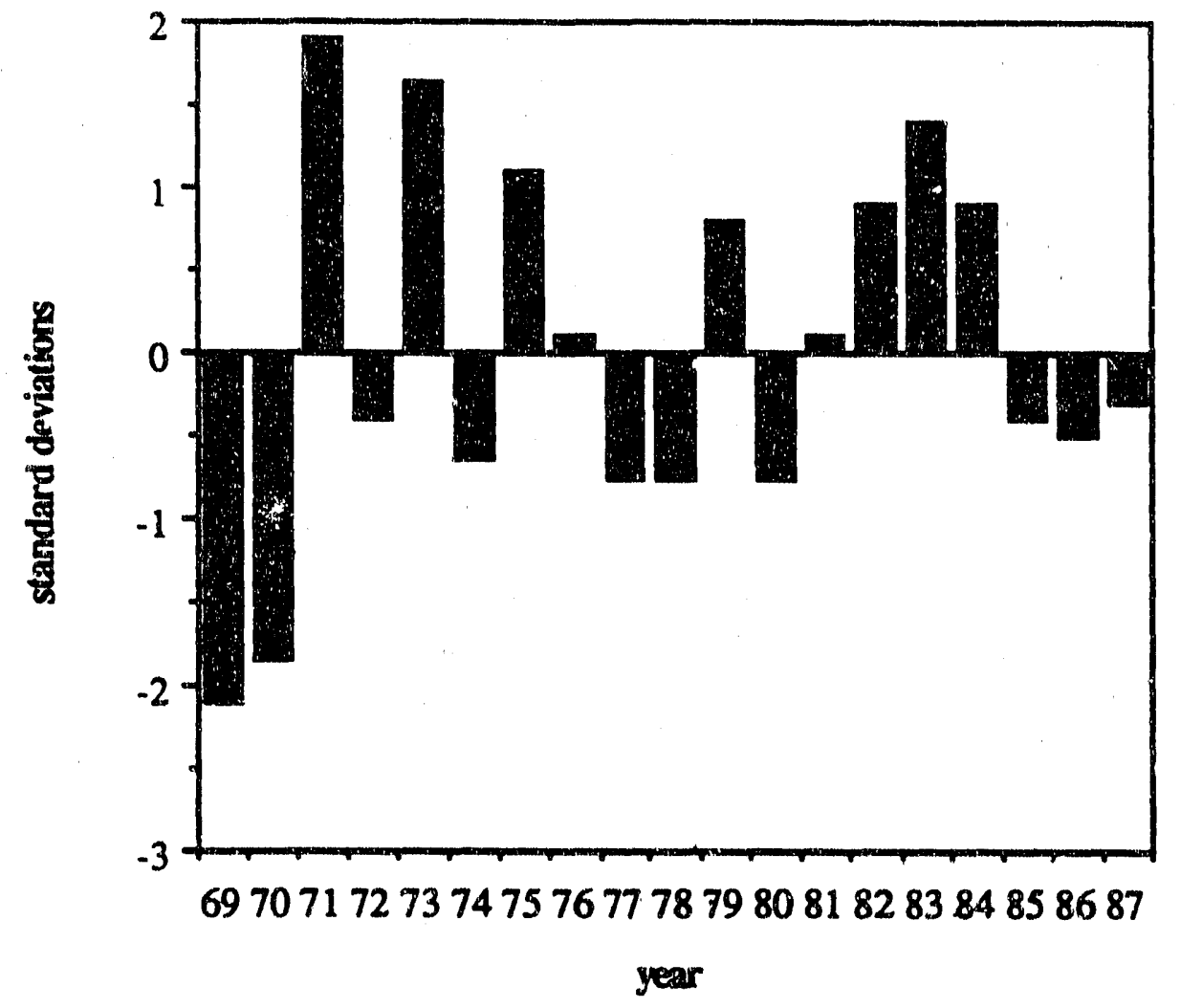

Figure 6. Standard deviation from mean annual precipitation 
Table 1. Savannah River Plant monthly precipitation data

\begin{tabular}{|c|c|c|c|c|c|c|c|c|}
\hline YEAR & Jan & Feb & Mar & Apr & May & Jun & Jul & Aug \\
\hline $\begin{array}{l}1968 \\
1969 \\
1970 \\
1971 \\
1972 \\
1973 \\
1974 \\
1975 \\
1976 \\
1977 \\
1978 \\
1979 \\
1980 \\
1981 \\
1982 \\
1983 \\
1984 \\
1985 \\
1986 \\
1987 \\
1988\end{array}$ & $\begin{array}{l}-1.98 \\
2.99 \\
5.6 \\
7.78 \\
5.5 \\
2.32 \\
4.98 \\
4.18 \\
3.72 \\
10.02 \\
3.59 \\
6.03 \\
0.89 \\
3.94 \\
3.73 \\
3.51 \\
3.01 \\
1.46 \\
7.39 \\
4.15\end{array}$ & $\begin{array}{l}-1.65 \\
2.67 \\
3.3 \\
3.65 \\
4.47 \\
6.66 \\
7.96 \\
1.08 \\
1.62 \\
1.31 \\
7.74 \\
3.48 \\
5.78 \\
4.45 \\
7.2 \\
7.09 \\
6.91 \\
3.54 \\
7.55 \\
3.18\end{array}$ & $\begin{array}{r}3.38 \\
7.64 \\
9.73 \\
2.60 \\
6.67 \\
3.03 \\
5.92 \\
3.83 \\
6.86 \\
3.06 \\
3.09 \\
10.96 \\
4.72 \\
2.50 \\
6.97 \\
6.05 \\
1.31 \\
4.08 \\
4.97 \\
2.90\end{array}$ & $\begin{array}{l}2.27 \\
4.06 \\
1.06 \\
2.36 \\
0.68 \\
4.55 \\
3.05 \\
4.42 \\
2.50 \\
1.27 \\
3.53 \\
6.49 \\
1.69 \\
2.07 \\
5.68 \\
5.92 \\
8.00 \\
0.84 \\
1.44 \\
0.67 \\
.4 .78\end{array}$ & $\begin{array}{r}3.28 \\
1.41 \\
3.12 \\
3.85 \\
4.39 \\
4.91 \\
3.35 \\
5.15 \\
10.99 \\
1.79 \\
3.64 \\
8.94 \\
3.49 \\
6.90 \\
2.82 \\
1.67 \\
9.79 \\
1.58 \\
3.83 \\
3.57 \\
2.85\end{array}$ & $\begin{array}{r}5.09 \\
4.11 \\
3.17 \\
4.04 \\
6.09 \\
12.97 \\
5.19 \\
3.83 \\
4.35 \\
2.47 \\
3.42 \\
1.54 \\
2.99 \\
4.29 \\
4.27 \\
6.57 \\
5.33 \\
4.61 \\
3.00 \\
5.64 \\
7.11\end{array}$ & $\begin{array}{r}3.03 \\
3.45 \\
5.28 \\
10.31 \\
2.18 \\
6.86 \\
4.44 \\
8.55 \\
1.95 \\
3.42 \\
4.11 \\
7.85 \\
0.90 \\
4.78 \\
11.47 \\
4.85 \\
7.28 \\
8.10 \\
2.96 \\
4.86 \\
1.78\end{array}$ & $\begin{array}{r}6.64 \\
3.73 \\
3.71 \\
9.00 \\
8.09 \\
3.90 \\
6.77 \\
3.83 \\
1.64 \\
7.30 \\
5.12 \\
2.12 \\
2.03 \\
5.79 \\
4.99 \\
6.32 \\
5.52 \\
4.37 \\
10.89 \\
4.92 \\
6.77\end{array}$ \\
\hline $\begin{array}{l}\text { Mean } \\
\text { Siddev }\end{array}$ & $\begin{array}{l}4.34 \\
2.18\end{array}$ & $\begin{array}{l}4.61 \\
2.24\end{array}$ & $\begin{array}{l}5.01 \\
2.48\end{array}$ & $\begin{array}{l}3.21 \\
2.10\end{array}$ & $\begin{array}{l}4.35 \\
2.66 .\end{array}$ & $\begin{array}{l}4.77 \\
2.32\end{array}$ & $\begin{array}{l}5.16 \\
2.85\end{array}$ & $\begin{array}{l}5.40 \\
2.31\end{array}$ \\
\hline YEAR & \multicolumn{2}{|c|}{ Sep } & Oat & \multicolumn{2}{|c|}{ Nov } & Dec & \multicolumn{2}{|c|}{ Annual } \\
\hline $\begin{array}{l}1968 \\
1969 \\
1970 \\
1971 \\
1972 \\
1973 \\
1974 \\
1975 \\
1976 \\
1977 \\
1978 \\
1979 \\
1980 \\
1981 \\
1982 \\
1983 \\
1984 \\
1985 \\
1986 \\
1987 \\
1988\end{array}$ & \multicolumn{2}{|c|}{$\begin{array}{l}5.57 \\
4.34 \\
2.06 \\
4.06 \\
2.09 \\
4.38 \\
3.32 \\
5.18 \\
5.48 \\
5.50 \\
4.06 \\
6.13 \\
5.86 \\
0.54 \\
4.62 \\
3.56 \\
0.60 \\
0.49 \\
1.82 \\
3.55 \\
4.40\end{array}$} & $\begin{array}{l}2.91 \\
0.63 \\
4.75 \\
4.94 \\
1.02 \\
1.72 \\
0.09 \\
1.74 \\
4.92 \\
4.27 \\
0.06 \\
1.35 \\
2.14 \\
2.81 \\
3.87 \\
2.48 \\
0.31 \\
6.34 \\
4.18 \\
0.29 \\
3.39\end{array}$ & \multicolumn{2}{|c|}{$\begin{array}{l}4.72 \\
0.23 \\
1.49 \\
3.14 \\
2.86 \\
0.98 \\
1.99 \\
3.41 \\
4.19 \\
1.63 \\
3.54 \\
3.95 \\
2.50 \\
1.00 \\
2.39 \\
5.38 \\
0.90 \\
6.36 \\
5.82 \\
2.74 \\
. .\end{array}$} & $\begin{array}{c}2.77 \\
4.40 \\
5.41 \\
2.73 \\
5.06 \\
3.99 \\
4.11 \\
2.03 \\
5.08 \\
4.14 \\
1.87 \\
2.17 \\
1.91 \\
10.55 \\
4.72 \\
4.15 \\
1.38 \\
2.48 \\
5.82 \\
1.41 \\
-.\end{array}$ & \multicolumn{2}{|c|}{$\begin{array}{l}34.37 \\
43.35 \\
63.06 \\
46.49 \\
60.90 \\
44.32 \\
57.00 \\
50.19 \\
43.99 \\
43.74 \\
54.96 \\
43.98 \\
50.12 \\
55.72 \\
58.80 \\
55.76 \\
46.40 \\
48.84 \\
47.56 \\
-. .\end{array}$} \\
\hline $\begin{array}{l}\text { Mean } \\
\text { Sidder }\end{array}$ & \multicolumn{2}{|c|}{$\begin{array}{l}3.70 \\
1.74\end{array}$} & $\begin{array}{l}2.58 \\
1.87\end{array}$ & \multicolumn{2}{|c|}{$\begin{array}{l}2.96 \\
1.68\end{array}$} & $\begin{array}{l}3.81 \\
2.07\end{array}$ & \multicolumn{2}{|c|}{$\begin{array}{r}49.98 \\
7.15\end{array}$} \\
\hline
\end{tabular}


decreased. Unfortunately, little information is available. Nineteen seventy-one had the highest precipitation with $33.2 \mathrm{~cm}(13.08$ inches) more than usual (approximately two standard deviations from the mean), suggesting that high precipitation levels alone do not cause tree stress since no major stress effects were evident in tree rings during that period (LeBlanc and Loehle, 1990).

Growing season (April 1 through October 1) precipitation data was analyzed since swamp tupelo is affected less by changes in hydrology and climate during the dormant season. The average growing season precipitation was $67.6 \mathrm{~cm}$ (26.6 inches) with a standard deviation of $14.5 \mathrm{~cm}$ (5.7 inches). Figure 7 shows the deviations from the mean of the growing season rainfall for the 20 vears of data. Nineteen sixty-nine, 1970, and 1985 were years of significantly low precipitation (between one and two standard deviations lower t'ian the mean) while 1980 had the lowest rainfall (greater than two standard deviations from the me $n$ ).
Nineteen seventy-seven was . Iso a very dry year. Again, low rainfall curing 1969 and 1970 and the year of abnormally high growing season rainfall (1973) occurred many years prior to tree mortality and stress and thus are not correlated to tree stress. The exceptionally low rainfall during 1980 , however, may have aggravated the tree mortality and stress which occurred during this time.

Figure 8 shows the mean monthly precipitation, while Table 2 shows the results of the data analysis for significantly high or low mean monthly values.

\section{Water Table.}

Since there are few wells in the wetland area and water table data are limited in the Hawthorn and Barnwell Formations, comparison of water table levels with surface elevations in order to determine the swamp history and surface water levels would be unreliable.

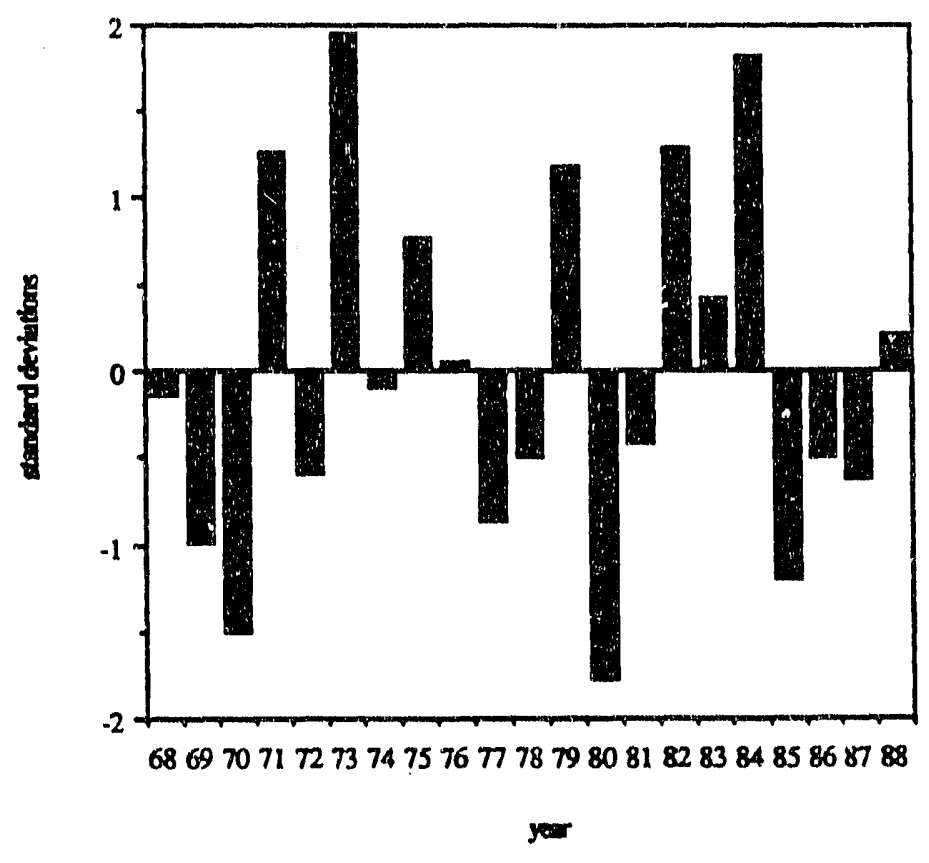

Figure 7. Standard deviation from mean growing season precipitation 


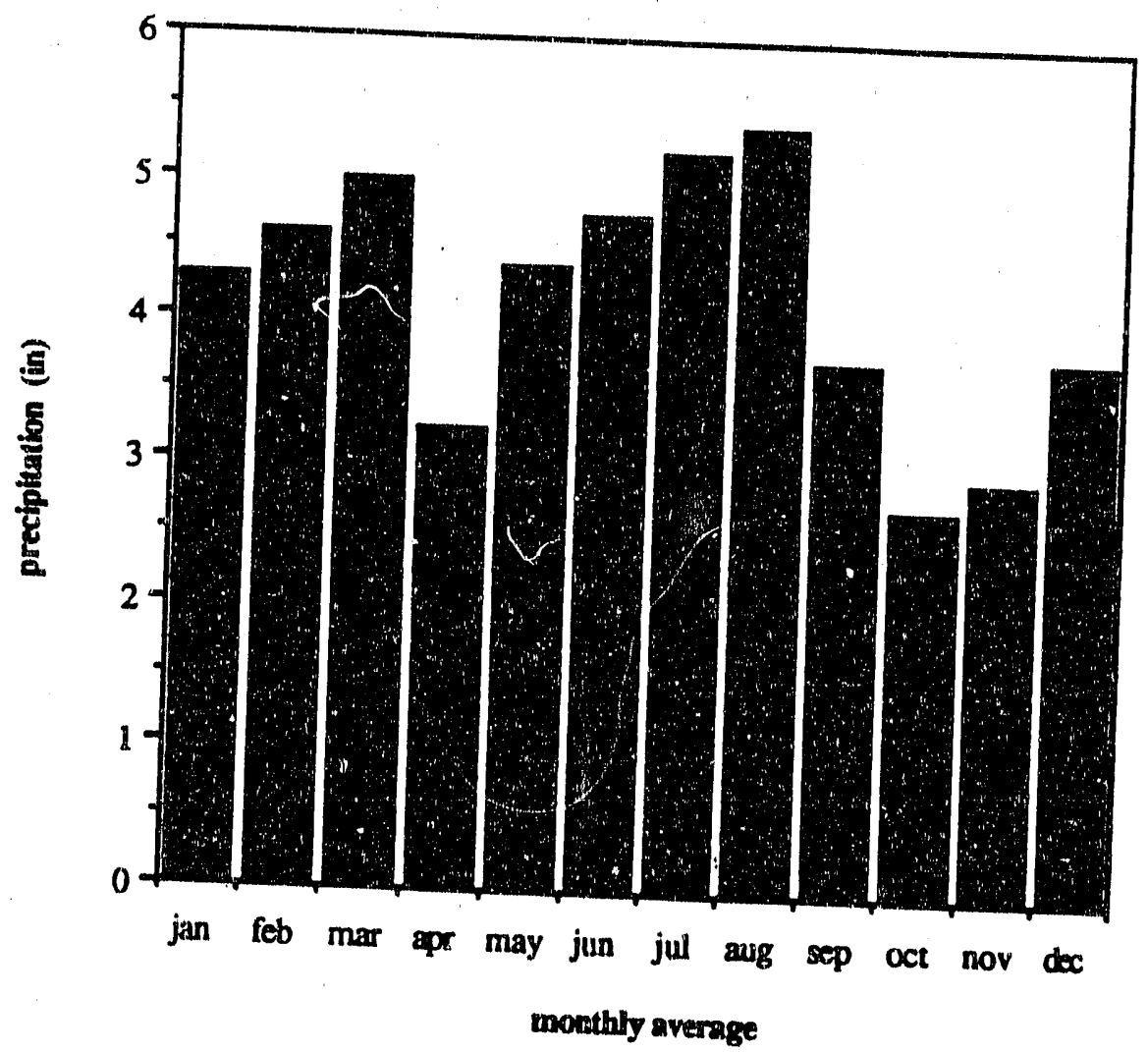

Figure 8. Mean monthly precipitation data 
Table 2. Summary of deviations from the mean monthly precipitation at the Savannah River Plant

\begin{tabular}{|c|c|c|c|c|c|c|c|c|c|c|c|c|c|c|}
\hline & Jan & $\mathrm{Feb}$ & $\mathrm{Mar}$ & Apr & May & Jun & Jul & Aug & Sep & $\mathrm{Oct}$ & Nov & Dec & Annu & Gro \\
\hline 1968 & $\ldots$ & $\ldots$ & & & & & & & $\mathrm{H}$ & & $\mathrm{H}$ & & ... & \\
\hline 1969 & L & 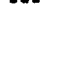 & $\mathrm{H}$ & & L & & & & & L & & & $L$ & L \\
\hline $\begin{array}{l}1970 \\
1971\end{array}$ & & & $\mathrm{H}$ & L & & & H & H & & $\mathrm{H}$ & & & $\mathrm{H}$ & $\begin{array}{l}\mathrm{L} \\
\mathrm{H}\end{array}$ \\
\hline 1972 & $\mathrm{H}$ & & & L & & & i & $\ddot{H}$ & & & & & & \\
\hline $\begin{array}{l}1973 \\
1974\end{array}$ & & $H$ & & & & $\mathrm{HHH}$ & & & & L & L & & $\mathrm{H}$ & $\mathrm{H}$ \\
\hline 1975 & & L & & & & & H & & & & & & & \\
\hline $\begin{array}{l}1976 \\
1977\end{array}$ & & $\mathrm{~L}$ & & & HH & & L & L & $\mathrm{H}$ & H & & & & \\
\hline $\begin{array}{l}1978 \\
1070\end{array}$ & $\mathrm{HH}$ & $\mathrm{H}$ & & & & & & & & L & & & & \\
\hline $\begin{array}{l}1979 \\
1980\end{array}$ & & & $\mathrm{HH}$ & H & $\mathbf{H}$ & L & L & $L$ & $\begin{array}{l}\mathrm{H} \\
\mathrm{H}\end{array}$ & & & & & L \\
\hline $\begin{array}{l}1981 \\
1982\end{array}$ & $H$ & $H$ & L & H & & & H & & L & & $\begin{array}{l}\mathrm{L} \\
\mathrm{H}\end{array}$ & HFH & & H \\
\hline $\begin{array}{l}1983 \\
1984\end{array}$ & & $\begin{array}{l}H \\
H\end{array}$ & & $\begin{array}{l}\mathrm{H} \\
\mathrm{HHI}\end{array}$ & $\begin{array}{l}\mathrm{L} \\
\mathrm{H}\end{array}$ & & & & L & L & $\begin{array}{l}H \\
L\end{array}$ & L & $H$ & $\mathrm{H}$ \\
\hline $\begin{array}{l}1985 \\
1986\end{array}$ & L & $\mathrm{H}$ & L & L & L & & L & $\mathrm{HH}$ & $\stackrel{L}{L}$ & $\mathrm{HH}$ & ${ }_{\mathrm{H}}^{\mathrm{H}} \mathrm{H}$ & & & L \\
\hline $\begin{array}{l}1987 \\
1988\end{array}$ & H & & & L & & H & $\mathrm{H}$ & & & L & & L & $\ldots$ & \\
\hline
\end{tabular}

L: Between 1 and 2 standard deviations lower than the mean L. Between 2 and 3 standard deviations lower than the mean H: Berween 1 and 2 standard deviations higher than the mean HH: Between 2 and 3 standard deviations higher than the mean HHH: Between 3 and 4 standard deviations higher than the mean Gro: Growing season total

Annu: Annual cotal 


\section{RESPONSE OF VEGETATION TO ALTERED HYDROLOGY}

Since hydrologic and vegetation data are limited, it is difficult to determine the status of the sites prior to and during tree mortality and stress. Mortality and stress bccurred relatively quickly and approximately at the same time at several sites. Thus, it is likely that tree mortality and stress were caused by the same stressor and/or site conditions.

\section{Annual Water Balance.}

The Thorthwaite Continuous Monthly Water Budget computer prograrn (McCabe, McLaughlin, and Muller, 1985) was run for the 19 years (1969 through 1987) of data (Figure 9), Results revealed no years where water availability to vegetation was limited.

The average amount of water available (potential evaporation less actual evaporation) for 1969 through 1987 was $12.73 \mathrm{~cm}(5.01$ inches) with a standard deviation of $7.27 \mathrm{~cm}$ (2.86 inches). Nineteen seventy, 1980, and 1985 had significantly lower water availabilities than normal with greater than one standard deviation from the mean, while 1973,1982 , and 1983 were the years which had significantly higher water availabilities at one standard deviation from the mean. Due to the lack of data, this program did not include seepage basin or natural groundwater inputs and thus underestimates water availability. Therefore, it is not likely that vegetation was damaged by drought alone, though drought could have acted to concentrate contaminants.

\section{Drought}

No information exists concerning the adaptive, site specific, and ecotypic responses of swamp tupelo to drought. However, several studies have shown an inverse relationship between flood and drought tolerance in various species (Dickson and Broyer, 1972; Gill, 1970; Keeley, 1979).

Annual precipitation data does show 1977,1978 , and 1980 to be drier than normal (Figures 5,6 ), but since precipitation does not seem to have a significant effect on water availability in the wetland this could only have a significant effect on swamp tupelo by aggravating another stressor such as pollutants.

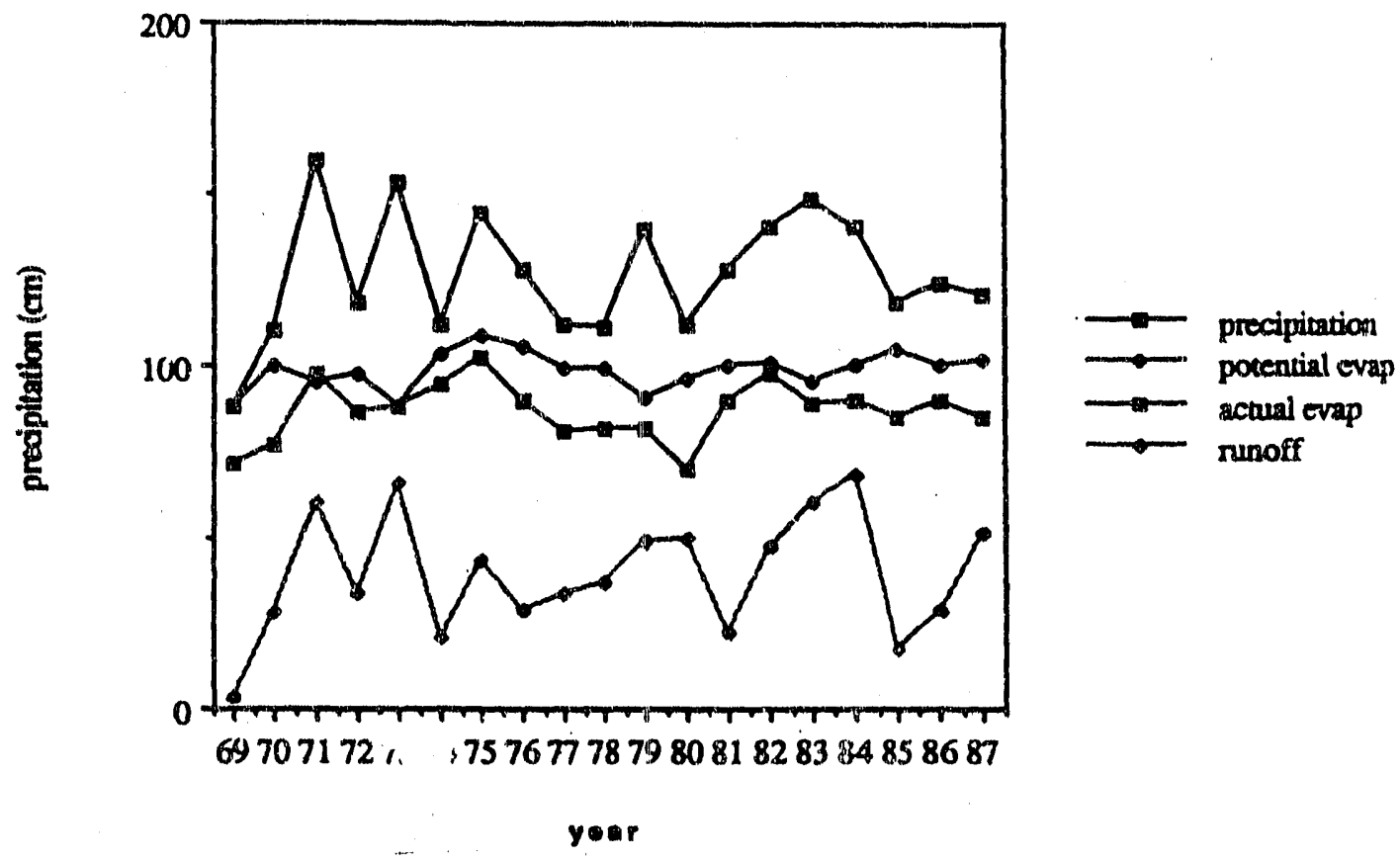

Figure 9. Thornthwaite Water Budget 


\section{Flooding}

Investigation of the stressed sites revealed that tree mortality occurred only in areas of saturated or flooded soils. These areas were occupied by nearly pure stands of Nyssa svlvatica var. biflora. Aerial photos from the early 1950s (Hal Mackey, pers. comm.) suggest the swamp areas near Four Mile Creek occurred naturally and did not result from water table rise due to seepage basin operation. This is verified by the ages of the wetland tree species occurring in the wetland, which predate 1955.

This information suggests that swamp tupelo stands were present prior to initiation of seepage basin operations in the F-and $\mathrm{H}$ Areas. In addition, since swamp tupelo is found, as opposed to water tupelo (Nyssa aquatica) or blackgum (Nyssa sylvatica) one can assume that the site has historically been waterlogged most of the year since such conditions promote great height and diameter growth in swamp tupelo (Keeley, 1979; Applequist, 1959; Briscoe, 1957). These species differentiate along a flood frequency gradient, where water tupelo has the greatest flood tolerance, followed by swamp tupelo and blackgum (Keeley, 1979; Harms, et al., 1980; Hook et al., 1971; Teskey and Hinckley, 1977a). Furthermore, differentiation occurs within each species (Keeley, 1979). Thus, swamp tupelo can be adapted to continually flooded swamps, to floodplains which are flooded periodically and well-drained the rest of the year, or to upland areas. For example, if a population is adapted to a floodplain it cannot tolerate long periods of saturated soils. However, another population adapted to continually flooded swamps could thrive.

A comparison of physiological adaptations to flooding explains these trends. Upland plants which live in drained soils transport less oxygen to the roots, allocate less biomass to the roots than shoots, and have high respiration rates (Keeley, 1979). When flooding occurs, succulent, secondary roots form which have intermediate respiration rates, allocate less biomass to roots than shoots, and significantly increase oxygen transport to the roots (Keeley, 1979).
This adaptation is temporary. Mortality will occur if flooding continues.

Swamp populations which are flooded over one year do not have succulent roots, but do have roots similar to drained roots. Root respiration rates are approximately the same as those for drained roots. These plants have the highest survival rates, the highest total biomass, and the lowest concentration of iron and manganese since they are able to oxygenate their roots.

Alternatively, floodplain populations vary with site conditions. When the site is drained, they behave similarly to upland species, with high respiration rates and more biomass allocated to roots than shoots. When the site is flooded, these species behave similarly io swamp species by initiating and maintaining healthy roots with an intermediate respiration rate, and allocate less biomass to roots than to shoots. Overall, these species have intermediate total biomass, intermediate accumulation of manganese and iron near the roots, and intermediate survival rates.

The impacted swamp tupelo stands, however, are approximately the same age and most likely have similar hydroperiods, resulting in similar flooding tolerances. They most likely are swamp species due to their location in shallow ponds (Applequist, 1959; Briscoe, 1957).

Unusual anatomical, metabolic, and hormonal adaptive responses are responsible for swamp adapted Nyssa sylvatica var. biflora 's ability to thrive in waterlogged soils (Hook, 1984; Keeley, 1979; Keeley and Franz, 1979; Hook, 1968; Hook, Brown, and Kormanic, 1971; Hook and Brown, 1972; Hook, Brown, and Wetmore, 1972; Hook and Brown, 1973; Teskey and Hinckley, 1977a; Applequist, 1959; Penfound, 1934). Stem lenticels, adventitious roots, swollen boles, and knees are the main features which improve the species' ability to tolerate anaerobic conditions for long durations. Stem lenticels are especially important since their function is to transfer oxygen from the atmosphere to the aerenchyma of the inner tree (Hook, 1984; Hook et al., 1972; Hook and Scholtens, 1978). The aeren shyma tissues are abundant 
and facilitate the movement of oxygen to the roots. When anaerobic conditions occur, the tree is able to regulate its metabolism and hormones and adapt by forming adventitious roots, which take advantage of the oxygen in the flood waters (Hook and Scholtens, 1978).

Nyssa sylyatica var. biflora is known to survive the following conditions:

- Prolonged shallow flooding (Hook, 1984)

- Abnormally high flooding (where lenticels are covered) for up to 25 percent of the growing season (Hall and Sinith, 1955)

Nyssa sylvatica var. biflora, however, cannot tolerate:

- Water levels covering the lenticels for over 26 percent of the growing season (Hall and Smith, 1955)

- Low oxygen availability (Briscoe, 1957; Hook and Brown, 1972; Hook, 1984)

- Stagnant water (Hook, 1984)

- High water temperature (Briscoe, 1957; Hook, 1984)

- Siltation (Teskey and Hinckley, 1977b)

- Reduced ions (Hook, 1984; Mitsch and Gosselink, 1986)

- Toxins prodiced in anaerobic environments (Hook, 1984; Keeley, 1979)

Given this information, it is possible to say that it is extremely unlikely that the trees could have been killed by flooding, nor would flooding likely aggravate toxicant stress since floodwaters would have a diluting effect. The topography dictates that no more than a few inches of water can accumulate above the soil surface before it runs off and Four Mile Creek is too small to flood these areas (B. Looney, pers. comm.).
Prolonged deep flooding would be necessary to kill blackgum. Such flooding would have killed upland species that are not flood tolerant in adjacent areas only a few inches in elevation above the area of tree kill. Thus flooding is not a likely cause of mortality. As a chronic effect, flooded soil conditions could, however, aggravate chenuical stresses.

\section{CONCLUSIONS}

Since seepage basin waste and natural groundwater are responsible for approximately 90 percent of the waters at the impacted sites (with rainfall making up the rest) and since well data are not available for the time of stress and mortality, it is not possible to rule out the possibility that water levels could have risen above the lenticels for greater than 26 percent of the growing season. However, topography and the pattern of tree kill make this highly unlikely. In addition, precipitation data does not show significantly high rainfall for a period long enough to cause stress and mortality in the sites. In contrast, dry years in 1977 to 1978 and 1985 to 1986 directly preceded periods of vegetation stress, implicating drought as an aggravating factor in conjunction with contaminants. A dry year in 1980 coincided with the tree kill period. Saturated soil conditions could, on the other hand, aggravate the effect of certain chronic stress agents, though not necessarily to an extreme degree. For comparison, one may think of a salt marsh, in which soils are anaerobic when flooded but become very salty when low tide leads to drying.

No information is available suggesting stagnant waters, high water temperatures, or abnormally high rates of siltation. These factors do not seem to be likely stressors.

Factors which may have caused tree mortality and stress alone or in conjunction with hydrological or climatological factors are discussed in the following sections of this report. 


\section{SOIL AND WATER CHEMICAL PARAMETERS}

\section{INTRODUCTION}

This section addresses factors involving the soil and groundwater systems which may have contributed to the tree mortality near Fand H-Area Seepage Basins of the Savannah River Site (SRS). First, we will describe the available data. The data will be used to identify potential contaminants and limit the scope of the literature review. Second is a literature review of those elements which may be important, as determined by concentrations in the soil or groundwater systems. The literature review will focus on changes the elements may cause in the soil system. Third, the information is synthesized in order to develop some hypotheses on the role of the soil system as it relates to tree mortality at the $\mathrm{F}$ - and $\mathrm{H}$-Area wetlands.

\section{Available Data}

Available data includes chemicals in the basins, contaminants seeping into the affected areas, and soil types in the affected areas. F. and H-Area Seepage Basins opened in 1955 and closed in 1988. A detailed account of what has been disposed of in the basins is not available. Killian et al. (1987a and 1987b) summarized the available information. The most important information, that regarding contaminant levels in soils during periods of stress, is not available. Recent water and soil samples in the aiffected areas can not provide a good record of the changes that may have been taking place before and during the period of mortality and could differ from conditions in 1977 to 1980 . Extensive and detailed groundwater sampling was initiated in 1982. Very little soil chemistry data is available in the affected areas prior to 1987 except for seepline sampling for tritium and nitrate in the late $1960 \mathrm{~s}$. Soil samples have been taken in 1987, 1988, and 1989 and results reported by Haselow et al. (1990) and this report. The 1989 soil samples have been analyzed by two laboratories, MetaTRACE and the Duke University Wetland Center, both included in Appendix A.
While this does provide some data, there are many problems, most of which arise from a lack of continuity. Different labs have been employed each year. This may lead to problems resulting from differences in quality assurance and control, and differences in methods of analysis. Also, the list of contaminants analyzed differs from year to year. Perhaps the most important problem relative to identifying the causes of tree mortality is that sampling is being conducted almost ten years after mortality. It is not reasonable to assume that the soil conditions are the same as when the stress began. In particular, highly mobile ions such as sodium and nitrate could be quite different over such a large span of time. Thus, at best the data can provide only an index as to the magnitude of contamination at the time of tree mortality.

\section{Literature Review}

The literature review is in two parts. An overview of wetlands chemistry is provided first. This provides an understanding of the major processes which drive wetland systems. It is important to recognize these processes since most reactions differ considerably between flooded and nonflooded conditions. Second, the chemistry of those elements identified as having a potential impact on the system will be reviewed in detail. Attention will be paid to those factors which may significantly alter the soil system.

\section{Synthesis}

The final section will bring together the information in the first two sections in order to develop hypotheses. These may take one of three forms. First, some contaminant or combination of contaminants has reached a level that is directly toxic to the trees. Second, some contaminant or combination of contaminants has destroyed the integrity of the soil system. This may have caused an interruption of nutrient cycling or resulted in a change in water relations. The third type of hypothesis is a combination of hypotheses previously presented. Combined effects may 
be necessary to take into account differences between the affected areas. A final evaluation of these hypotheses incorporates information on tree responses to contaminants, which is in the next chapter.

\section{GROUNDWATER AND SOIL CHEMISTRY}

Information on the fate and migration of contaminants is only partially available since soil and well-water sampling data are generally not available before 1977 , the year in which stress was first observed (LeBlanc and Loehle, 1990; Mackey, 1988). There is some groundwater data available from the late 1960 s and early 1970 s, but it only pertains to nitrates and tritiurn which appeared along the seepline in the mid-sixties (Killian et al., $1987 \mathrm{a}, \mathrm{b})$. Sampling of well water for a wide range of possible contaminants was not initiated until 1982. Looney et al. (1988) reported the results of soil water samples taken in 1987 at the seepline. It was concluded that the concentration of various constituents in the soil water is a result of contributions from the seepage basins. Additional soil samples and soil water samples have been taken in the affected areas in 1988 and 1989 (presented in Appendix B). The results of these samples have not previously been examined. Lower (1985) reported the results of a study done on the concentrations of metals and radionuclides in sediments in the major rivers and streams on the Savannah River Site. It was thus determined before the study began that only heavy metals were of concern for Four Mile Creek. Pesticides and organics were not considered to be important, and testing revealed all protocol organics to be below limits of detection (Lower, 1985).

Contaminant concentrations in the $\mathrm{F}$ Area water table wells during 1985 were highest for sodium, nitrate, and cadmium. The following factors were identified as probable groundwater contaminants: $\mathrm{pH}$, sodium, nitrate, total dissolved solids, gross alpha and beta emissions, and radium (Killian et al., 1987a).

According to Killian et al. (1987a), nitrate concentrations downgradient of
F Area in 1968 through 1969 ranged from 100 to $300 \mathrm{mg} / \mathrm{L}^{-1}$ compared with $3 \mathrm{mg} / \mathrm{L}^{-1}$ in ambient shallow groundwater. Along the seepline, nitrate levels in more contaminated areas rangea from $174-546 \mathrm{mg} / \mathrm{L}^{-1}$ in 1987. Discharge estimates into Four Mile Creek between August and September 1973 were estimated at 65 tons per year.

Wells were sampled around the basin initially in March 1982 for nitrate, sodium, cadmium, mercury, and tritium (Killian et al., 1987a). These are the well values used in the following figures.

Figures 10 through 19 compare control and contaminated levels for: (a) groundwater, (b) soil water, and (c) soil core metals in both F-and H-Areas. In the groundwater, the abbreviation, back., designates wells located above the seepage basins. The abbreviation, degr., indicates wells located between the seepage basins and the affected areas. For the soil water and soil cores the abbreviation, $F$-degr., indicates the wetland area which has encountered the greatest stress. There are currently no living trees in this area. The $F$ inter sice exhibits moderate stress but few dead trees. The abbreviation, $\boldsymbol{H}$-Area, indicates areas of intermediate stress in the H-Area. In these areas, most trees are dead, although the understory is viable and there are a few canopy trees surviving, although obviously stressed. Control is an area located upstream from the affected areas and unaffected by the seepage basins.

The groundwater and soil water data are from 1989. Groundwater data was reported by Exploration Research (1989). Soil water data was reported by Haselow et al. (1990) for data analyzed by Thermoanalytic Laboratories, hereafter TMA. Total metals from soil cores are from 1988 and 1989. The 1988 soil cores are from TMA (Haselow et al., 1990), and the 1989 samples are from MetaTRACE (Appendix A) except as noted below. Locations of the sampling areas are shown in Figure 1. Details on methods of analysis for all previously unpublished data are in Appendix A. The samples from a given site (e.g. F-degr.) are only approximately from the same locations, which explains some of the differences between the different years and analyses. 
For the TMA soil water data, wetland surface water was sampled at sites $88 \mathrm{FW} 1$ and 88FW2 (see Haselow et al., 1990 for detailed map and Figure 1 this report) which were averaged for $F \cdot d e g r$. site, and $88 \mathrm{FW} 3$ and $88 \mathrm{FW} 4$ which were averaged for the $\boldsymbol{F}$-inter site. $88 \mathrm{HW} 1$ was used for $\boldsymbol{H}-\mathrm{Area}$. The 1988 TMA soil core data are from sites
$88 \mathrm{FS} 1$ and $88 \mathrm{FS} 11$, depths 70 to $80 \mathrm{~cm}$, for $F$-degr., and 88FS3 (average of 10 to 20 and 100 to $110 \mathrm{~cm}$ deep samples) for $F$ inter. For H-Area, $88 \mathrm{HS} 4$ data were averaged for $\mathrm{H}-\mathrm{Area}, 88 \mathrm{HS} 4$ data were averaged for the 50 to 60 and 100 to $110 \mathrm{~cm}$ depths. The control site for TMA data for soil water was $89 \mathrm{FW}$ land for soil was
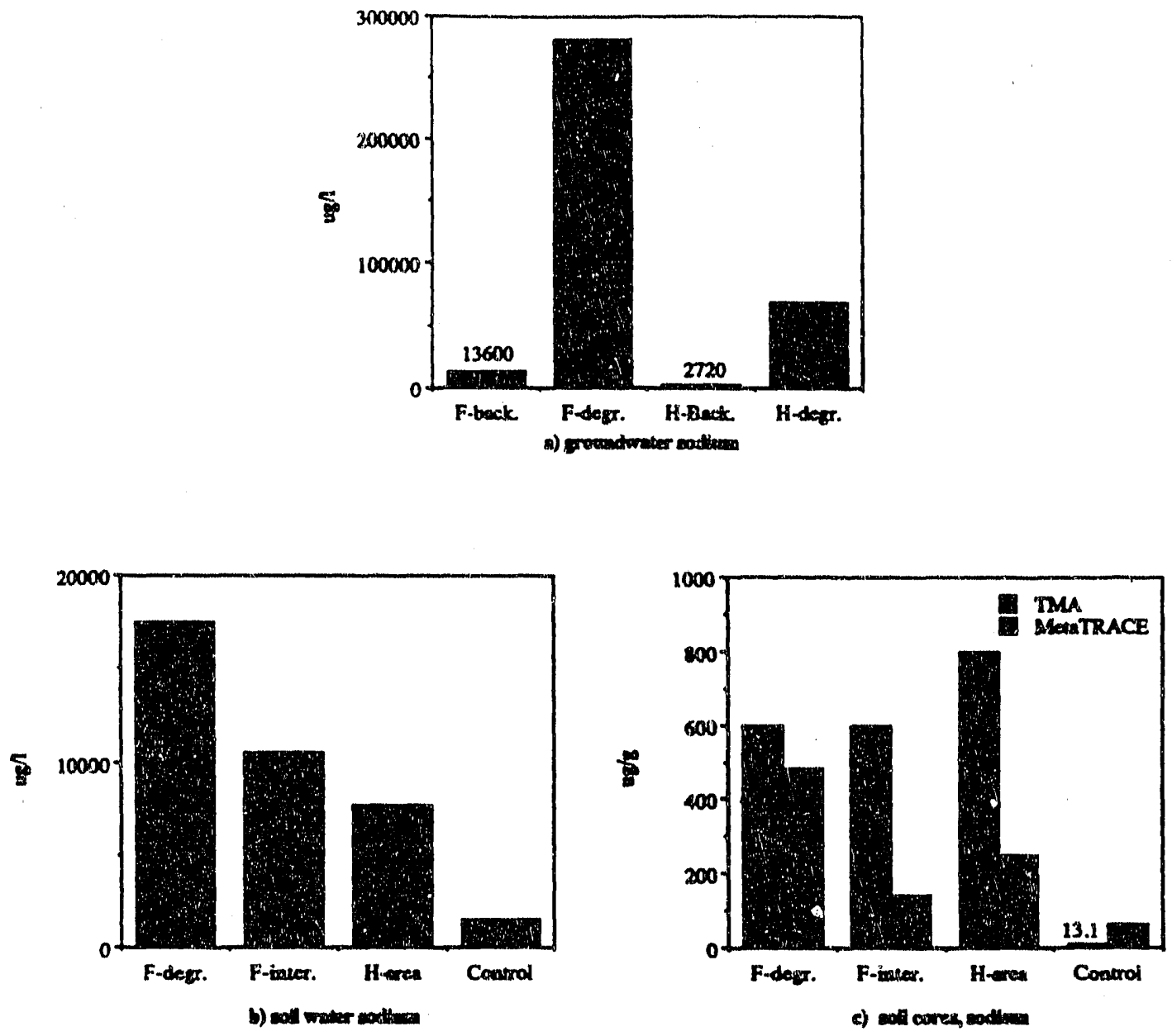

Figure 10. Sodium concentrations in the a) groundwater (Exploration Resources, 1989), b) soil water (TMA, 1988) and c) soil cores (TMA, 1988; MetaTRACE, 1989) 

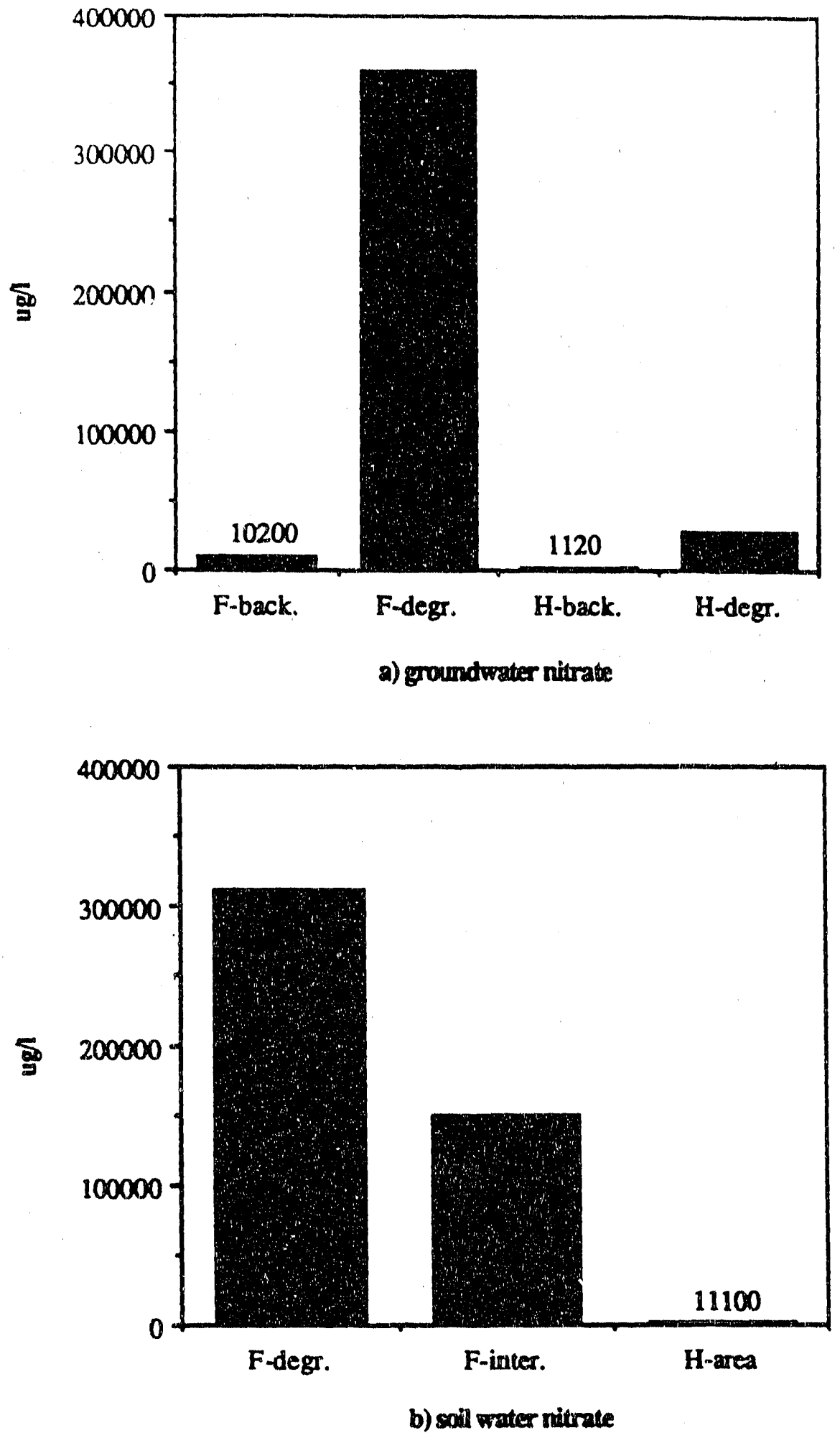

Figure 11. Nitrate concentrations in a) groundwater (Exploration Resources, 1989) and b) soil water (Risselow et al., 1990) at the SRS 


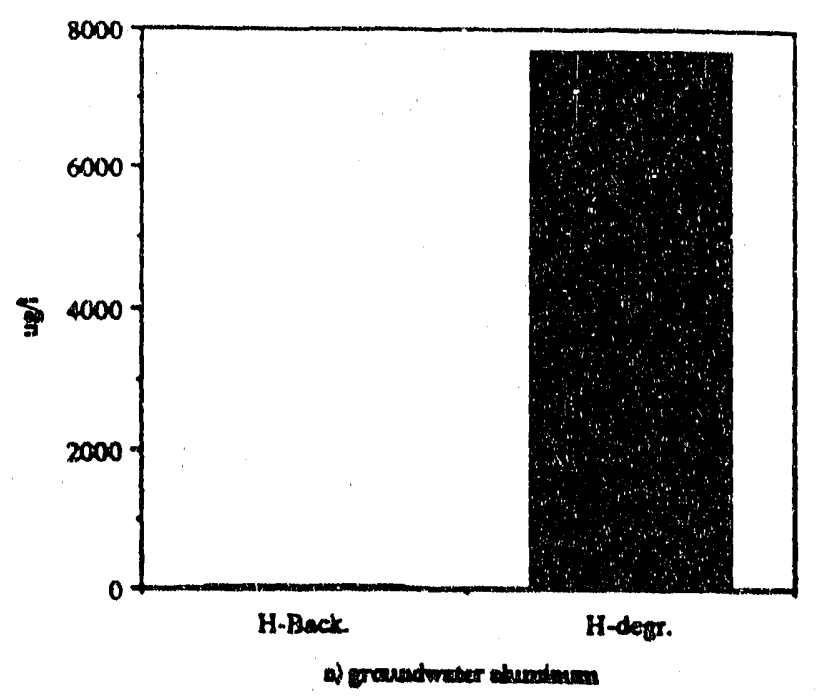

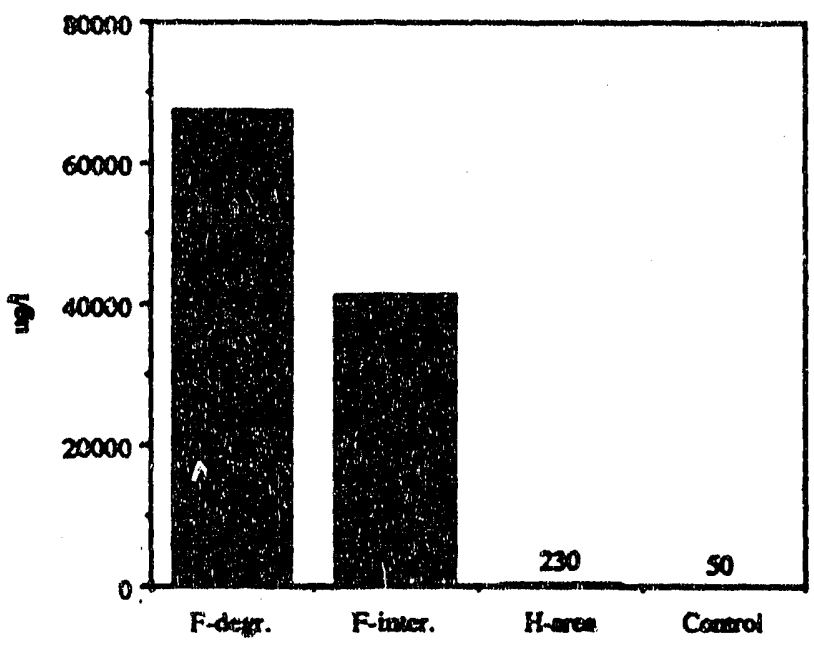

b) soll wator aleminum

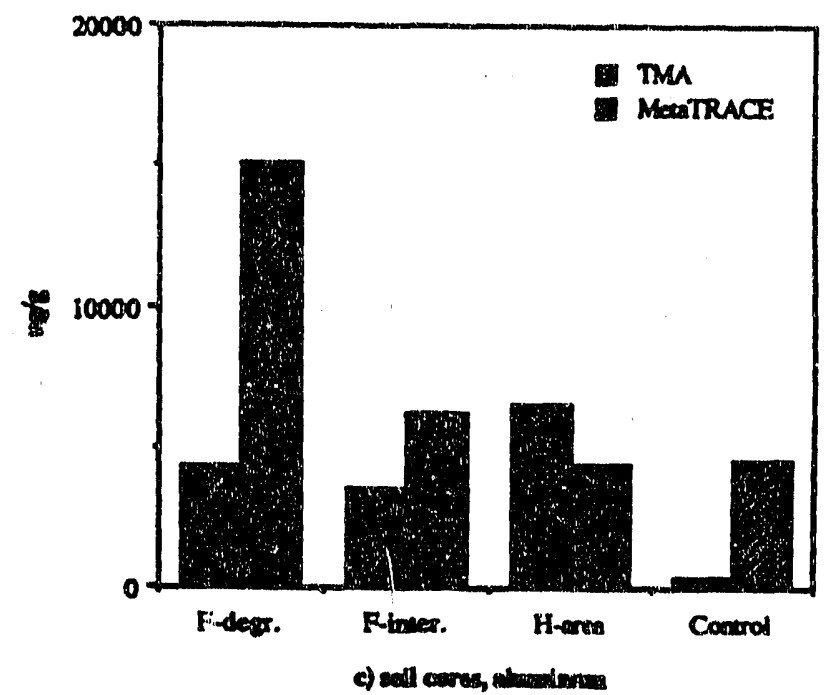

Figure 12. Aluminum concentrations in the a) groundwater (no data from F-Area; Exploration Resources, 1989 ), b) soil water(TMA, 1988), and c) soil cores (MetaTRACE, 1989) at the SRS 


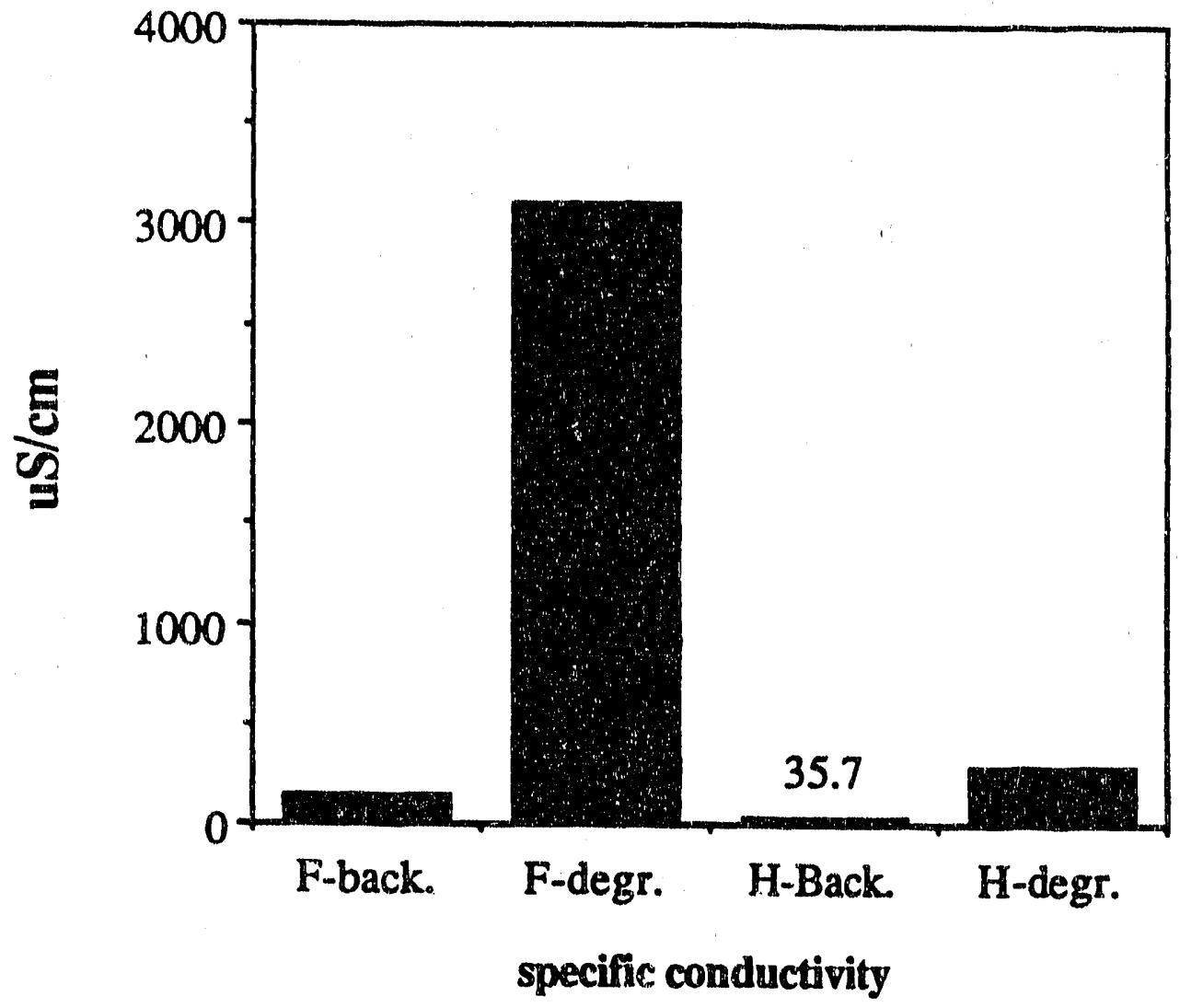

Figure 13. Specific conductivity in the groundwater (Exploration Resources, 1989) 


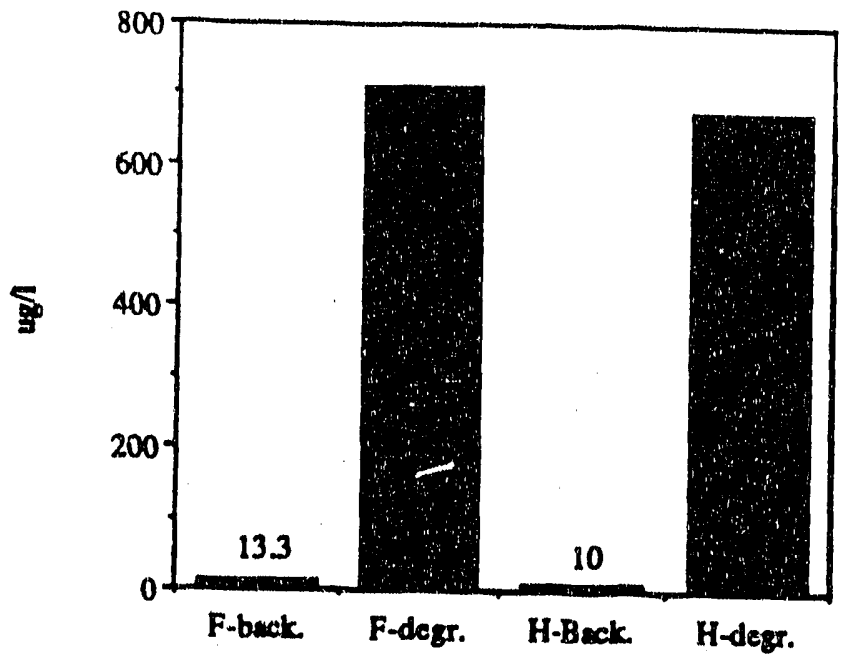

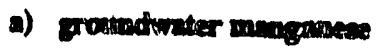

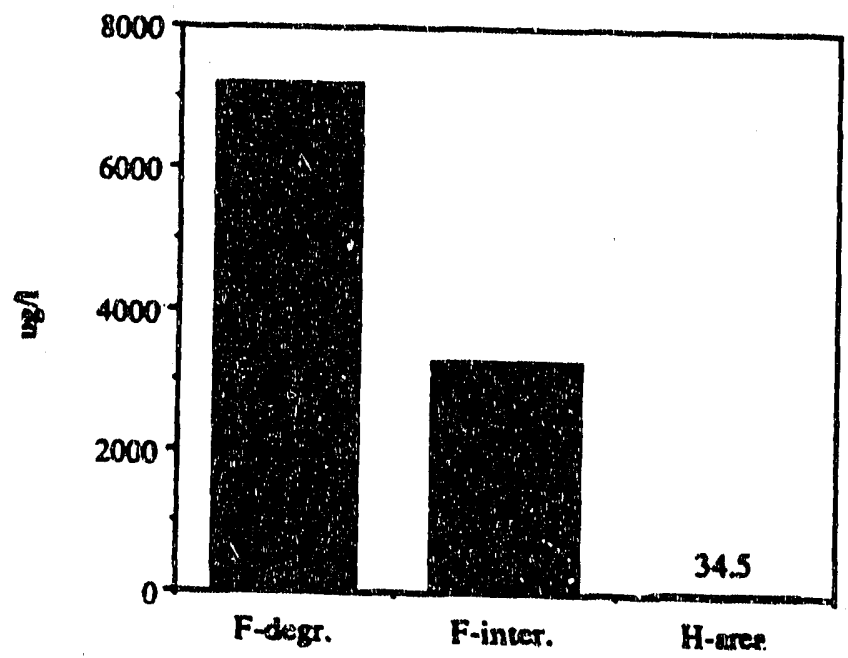

b) will water mangamese

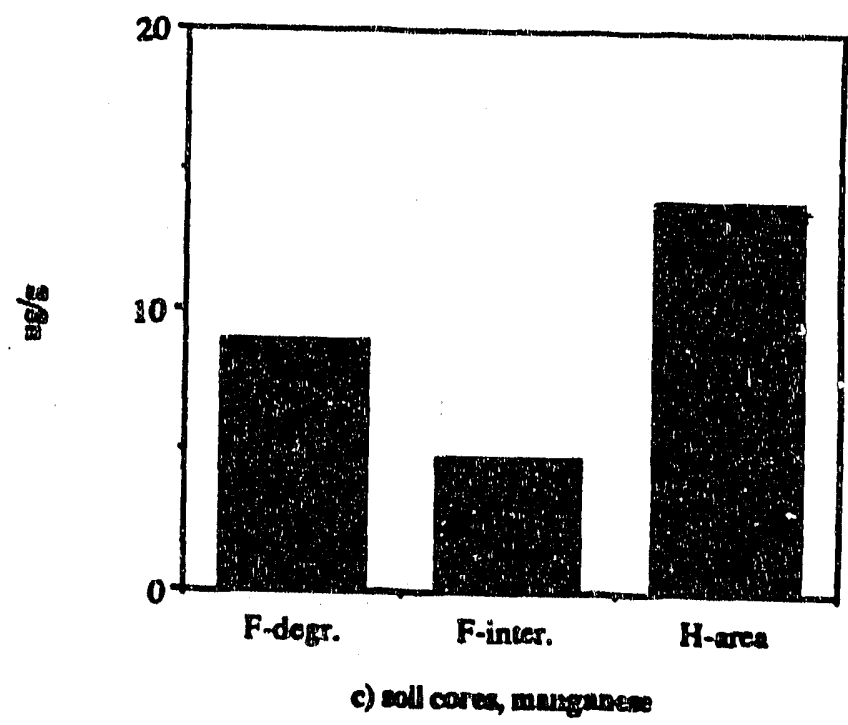

Figure 14. Manganese concentrations in the a) groundwater (Exploration Resources, 1989) b) soil water (TMA, 1988) and c) soil cores (TMA, 1988; MetaTRACE, 1989) at the SRS 

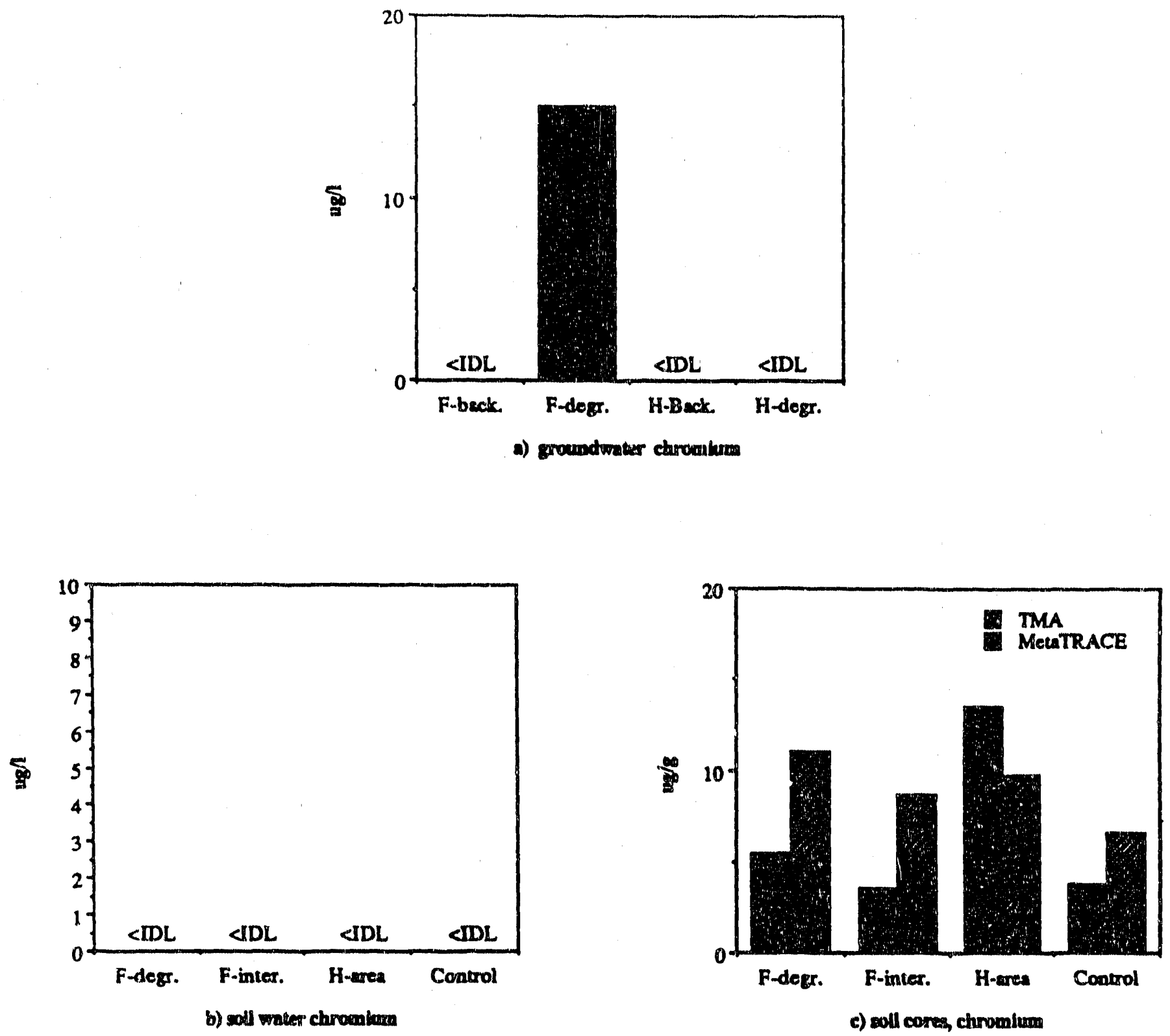

Figure 15. Chromium concentrations in the a) groundpater (Exploration Resources, 1989), b) soil water (TMA, 1988) and c) soil cores (TMA, 1988) and c) soil cores (TMA, 1988; MetaTRACE; 1989) at the SRS 

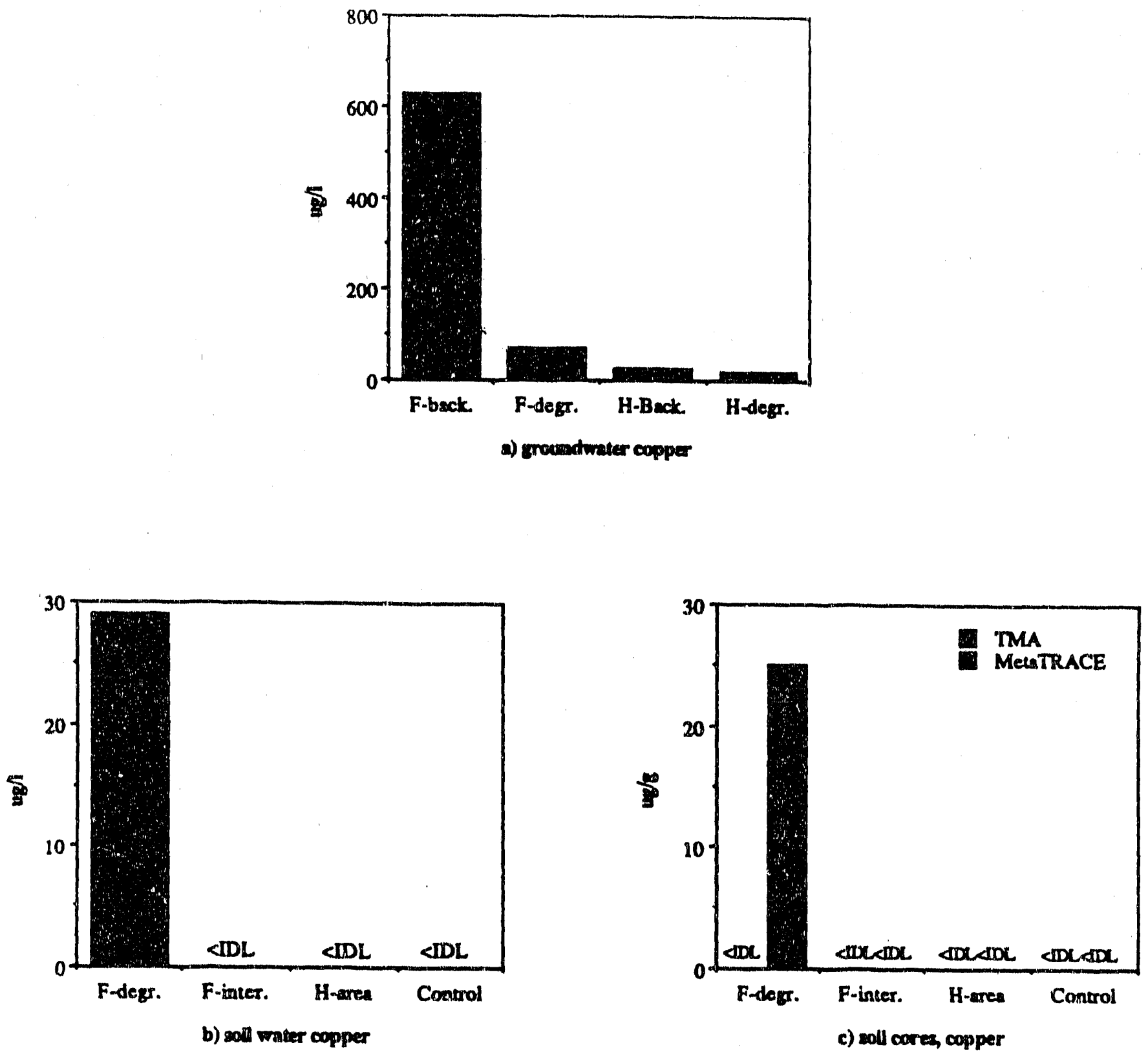

Figure 16. Copper concentrations in the a) groundwater (Exploration Resources, 1989), b) soil water (TMA, 1988), and c) soil cores (TMA, 1988; and MetaTRACE, 1989) at the SRS 


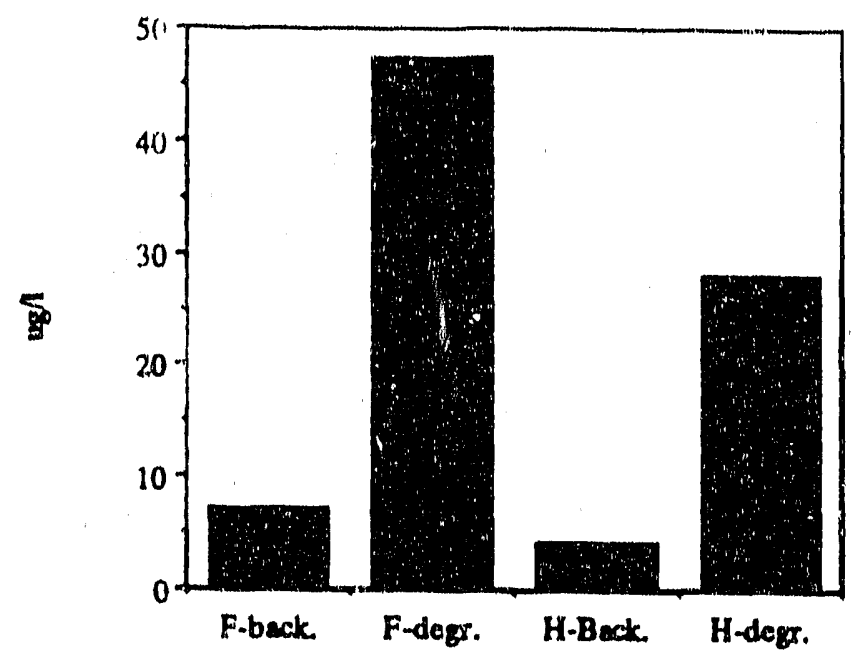

v) groundwater nicted

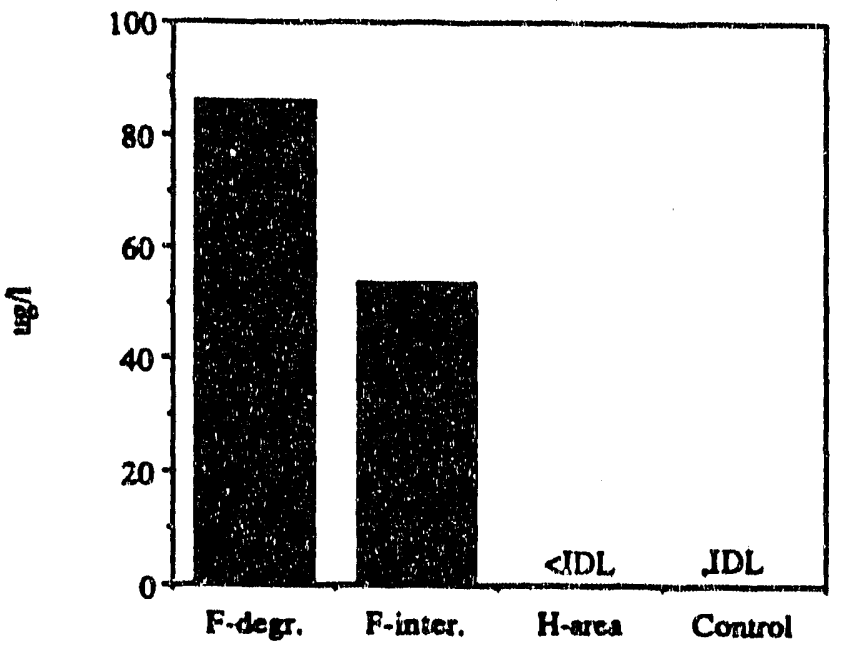

b) woll water neletred

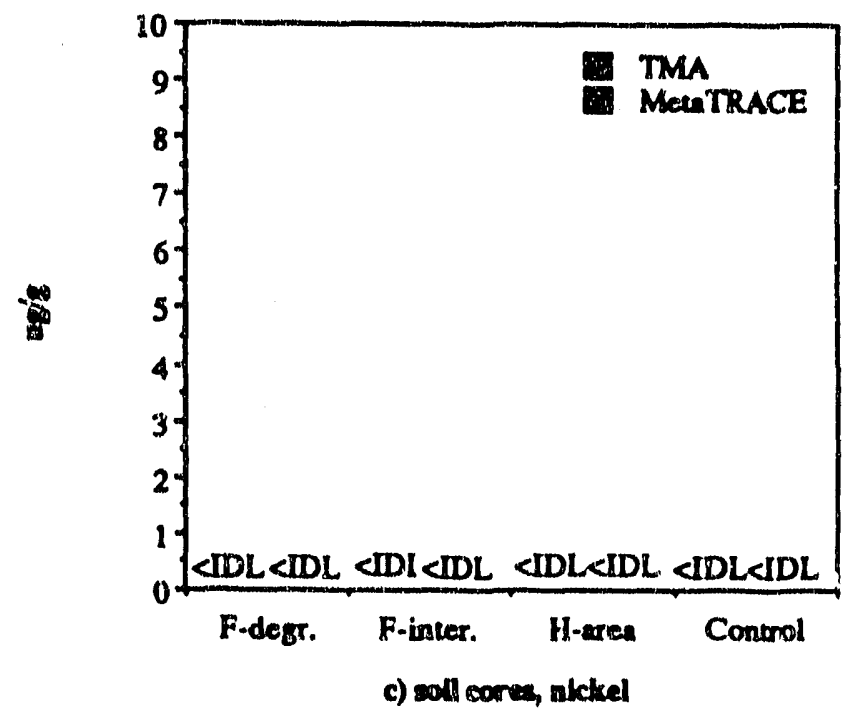

Figure 17. Nickel concentrations in the a) groundwater (Exploration Resources, 1989) b) soil water (TMA, 1988) and c) soil cores (TMA, 1989; Meta Trace, 1989) 


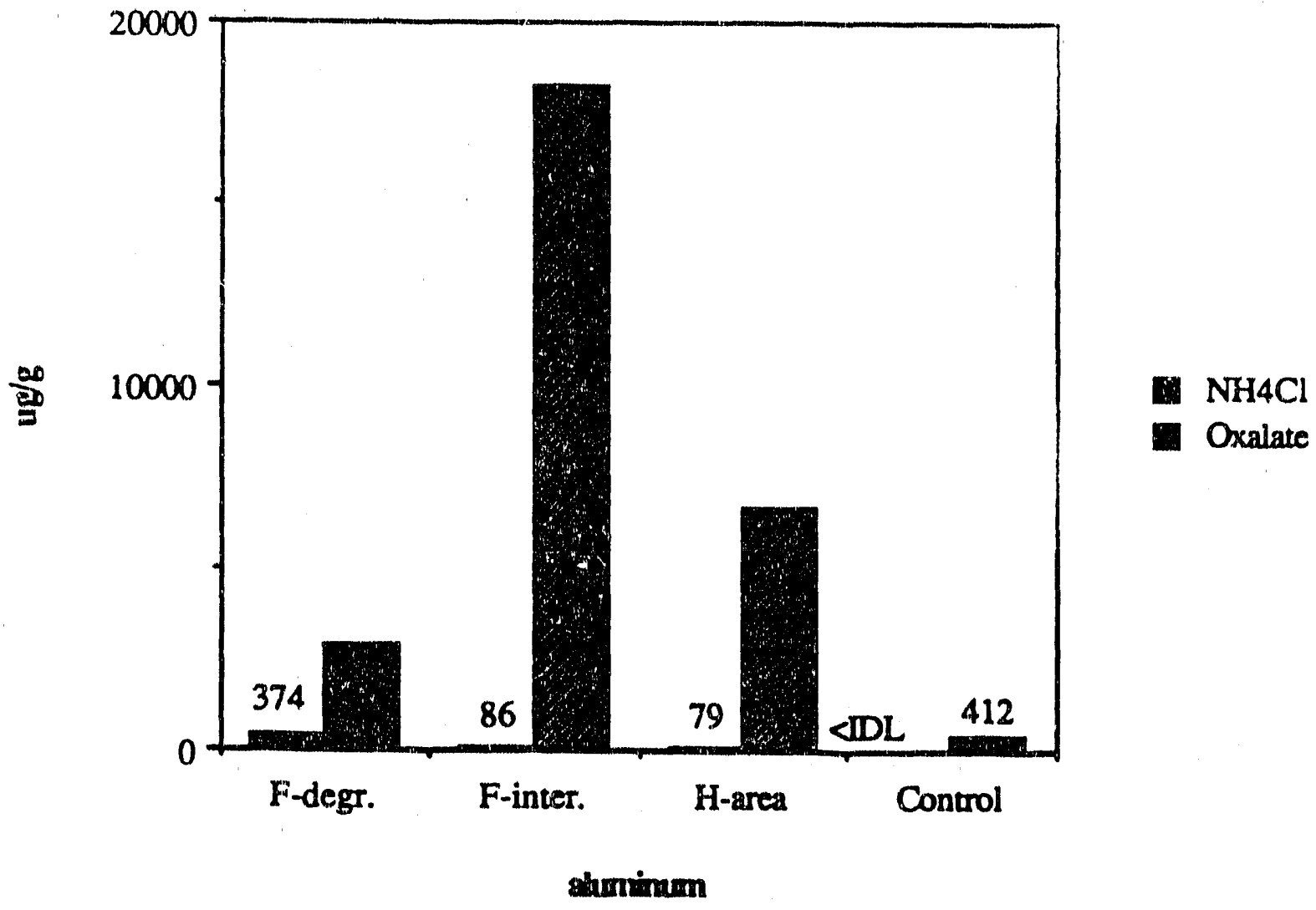

Figure 18. Comparison of $\mathrm{NH} 4 \mathrm{Cl}$ and oxalate extraction procedures for aluminum at the impacted areas near F-and H-Area Secpage Basins (Duke University Wetlands Center, 1990) 


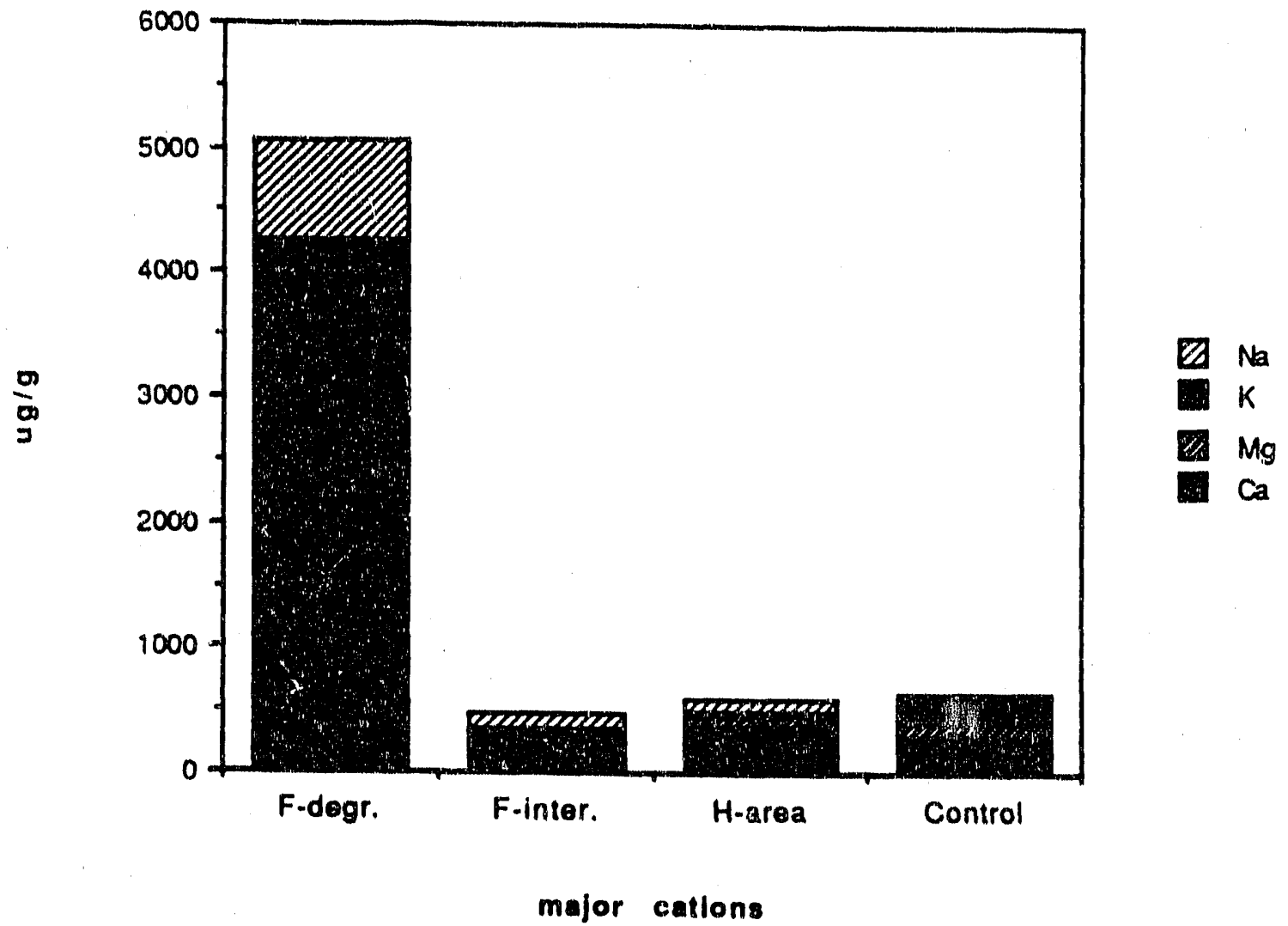

Figure 19. Major cations in soils at affected areas near F- and H-Area Seepage Basins (Duke University Wetland Center, 1990). 
89HS2B and 89HS2I (averaged), which were downstream of the $F$ basins and upstream of the $\mathrm{H}$ basins, respectively.

Element concentration in soils is a combination of the fixed portion $\left(C_{F}\right)$, the adsorbed portion $\left(C_{A}\right)$, and the concentration in the pore waters $(\mathrm{CW})$. The fixed portion is considered immobile. The adsorbed portion and pore water portion are considered potentially mobile, with the latter being most available for uptake (Dragun, 1988). At background concentrations, it is generally the case that $\mathrm{CF}_{\mathrm{F}} \gg \mathrm{C}_{\mathrm{A}}>\mathrm{CW}$. Analytic data which gives the total elemental concentrations in soil relays no useful information regarding $\mathrm{C}_{\mathrm{F}}, \mathrm{C}_{\mathrm{A}}$, or $\mathrm{CW}_{\mathrm{W}}$ other than the magnitude of the combined concentrations. The extraction procedure utilized by the United States EPA (Dragun, 1988) provides a soil extract value $\left(C_{E}\right)$ that is a linear combination of the concentrations such that $\mathrm{C}_{\mathrm{T}}>\mathrm{C}_{\mathrm{E}}$; where $\mathrm{C}_{\mathrm{T}}$ is the total concentration in the soil (Dragun, 1988). This information does not provide the information needed to determine potential migration and transformations of an element in the soil. It does provide an upper bound on quantities that might be made available, although it overestimates the concentration to which plants are exposed. Well water and soil water data (following) thus represent $\mathrm{C}_{\mathrm{W}}$, while soil core acid digest data represent $C_{T} . C_{A}$ was estimated for several ions in data analyzed at Duke University. Thus these several sources of data can be combined to estimate the total loadings and current and potential mobilities of the suspect toxic agents.

Figure 10 compares sodium in the groundwater, soil water, and soil cores. Figure 10a shows that sodium is an order of magnitude larger in the F-Area degraded well when compared to the F-Area background well. Sodium concentrations in the H-Area degraded well are an order of magnitude larger when compared to the H-Area background well, but an order of magnitude less than the F-Area degraded well. The soil water data in Figure $10 \mathrm{~b}$ shows both $F$. inter. and $F$-degr. values to be larger than the H-Area which is far higher than the control site. TMA analysis of soil cores, Figure $10 \mathrm{c}$ indicates the $\boldsymbol{F}$-degr. and $\boldsymbol{F}$. inter. values to be the same. $\boldsymbol{H}$-Area. soil core values are greater than $\boldsymbol{F}$-A rea. values. MetaTRACE analyses indicate a large difference between the $F_{-d e g}$. and $\boldsymbol{F}$. inter. areas, but both are still much larger than the Contrul. H-Area. is an order of magnitude larger than the control.

Figure 11 compares nitrate in the groundwriter and soil water. Nitrate in the groundwater is about four times larger in the $F$-degr. well than in the $F$-back. well (Figure 11a). H-Area groundwater nitrate is greater in the degraded well than in the background well, but considerably less than the $F$-degr. well. Soil water nitrate is twice as large in $\boldsymbol{F}$.degr. when compared to $\boldsymbol{F}$. inter $\mathbf{H}$-Area. soil water nitrate is much less than in $\boldsymbol{F}_{\mathbf{n}}$ Area.

Figure 12 shows aluminum concentrations in the soil water and soil cores. Aluminum was not analyzed for in the groundwater sampling program for $\boldsymbol{F}$-Area. H-Area groundwater aluminum, Figure $12 \mathrm{a}$, is three orders of magnitude larger in the degraded well than in the background well. Soil water aluminum, Figure $12 \mathrm{~b}$, is larger in $\boldsymbol{F}$-degr. than in $\boldsymbol{F}$ inter.area. H-Area soil water aluminum is two orders of magnitude less than the $F$. Areas and is slightly higher than the control. Aluminum concentrations in soil cores as reported by TMA, Figure $12 \mathrm{c}$, are very similar in the $F$-degr. and $F$-inter. areas. H-Area soil core values are greater than $F$-degr. for TMA data and an order of magnitude less for the MetaTRACE data. Soil cores as reported by MetaTRACE in 1989 show $F$-degr. values to be an order of magnitude larger than the $F$-inter. and control area values. H-Area aluminum is similar to the control value for MetaTRACE data, but elevated for TMA data.

Figure 13 shows specific conductivity in the groundwater. Contaminated wells in the F-Area (degraded) have specific conductivity thirty times larger than the background wells. $\mathrm{H}$-Area degraded wells are ten times the value found in the control wells.

Figure 14 illustrates manganese concentrations in the groundwater, soil water, and soil cores. Manganese in the $F$ and $\boldsymbol{H}$-Area groundwater, Figure $14 \mathrm{a}$, is an order of magnitude higher in the degraded 
area wells as compared to the background wells. F.degr. area soil water contains twice as much manganese as does the $F$ inter. soil water (Figure 14b). H-Area soil water manganese is far lower than $F$-inter. Soil cores analyzed by TMA show the same pattern as the soil water, except that manganese in the soil is highest in $\boldsymbol{H}$-Area (Figure 14c). MetaTRACE did not analyze for manganese.

Figure 15 shows chromium concentrations in the groundwater, soil water, and soil cores. Groundwater chromium, Figure 15a, is elevated only in the F-degr. area. Groundwater in the F-Area background well and $\mathrm{H}$-Areas is reported as the limit of detection. Soil water chromium for F-Area (Figure 15b) is greater in the degraded area than the intermediate area. $H$ Area soil water rhromium concentration is just at the TMA limit of detection, though all soil water values are less than the MetaTRACE instrument detection limit (IDL). Soil core chromium, Figure 15c, shows the same pattern for TMA and MetaTRACE data in the F-Area, although the MetaTRACE data is twice as high for the TMA data as for the $\boldsymbol{F}$-Area. TMA reports chromium levels greater than MetaTRACE for the H-Area. These values are thus elevated compared to the control soil cores, but not to an extreme degree.

Figure 16 shows copper concentrations in the groundwater, soil water, and soil cores. F.Area groundwater copper is an order of magnitude higher in the background wells than the degradenl wells (Figure 16a). H-Area groundwater copper is slightly higher in the background wells than the degraded wells. Soil water copper (Figure $16 \mathrm{~b}$ ) is less than the instrument detection limit for all soil water and soil core values except for $F$-degr., which is slightly above the IDL in both cases.

Figure 17 shows nickel concentrations in the groundwater, soil water, and soil cores. $F$-Area groundwater nickel is four times larger in the degraded wells than the background wells (Figure 17a), H-Area groundwater nickel is three times larger in the degraded wells than the background wells. $F$-Area soil water values are slightly above the IDL for F-degr. and inter., but $\boldsymbol{H}$ Area soil water and all soil cores are less than the IDL.

Zinc data from TMA for soil water showed $\boldsymbol{H}$-Area to be below the IDL and the $\boldsymbol{F}$. Area sites to be somewhat elevated. Soil core data showed zinc at $\boldsymbol{H}$-Area to be just above the IDL and the $F-A$ rea sites to be elevated, with $F$-degr. being highest.

Figure 18 compares the $\mathrm{NH}_{4} \mathrm{Cl}$ and oxalate extraction methods for aluminum (data in Appendix A). The oxalate extraction procedure measures the amorphous aluminum content in soils and gives some index of aluminum that may be available to plants or mobile in the soil system. The $\mathrm{NH}_{4} \mathrm{Cl}$ procedure measures exchangeable aluminum only. Figure 18 shows that readily available (oxalate extractable) aluminum is orders of magnitude higher than the fixed portion in the $F$-degr area. H-Area aluminum values are less than the control and $\boldsymbol{F}$-Areas. This siggests that aluminum may be easily leached and mobile in the system and that the levels of available aluminum in the $\boldsymbol{F}$-degr. areas may be sufficient to be highly toxic (discussed further below).

Figure 19 compares the quantity of major cations (calcium, magnesium, potassium, and sodium) as measured by the $\mathrm{NH}_{4} \mathrm{Cl}$ extraction procedure. Levels in the control and $F$-inter. areas are quite similar in total cation content. For each cation, all concentrations are similar, except potassium, which is higher in the control than any other area. Cation concentrations in the $\boldsymbol{F}$-degr. area are an order of magnitude larger than the other areas. The difference is entirely due to calcium, magnesium, and sodium. Total cations in the $\boldsymbol{H}$-Area are similar to the $\boldsymbol{F}$. inter. area. The slightly larger total results from a larger calcium content.

\section{Summary}

From the available data, it is clear that sodium, aluminum, manganese, zinc, cadmium, nitrate, and acidity are sufficiently high to warrant closer examination. Copper, chromium, and nickel were either below detection limits or just above detection limits, 
and are thus not likely causes of mortality. The chemistry of wetlands makes it possible that some constituents were previously at toxic levels and have been leached from the soil. The following section discusses mobility of these constituents and interactions between them, as well as their effects on soil properties.

\section{SOIL CHEMISTRY AND ITS INFLUENCE ON ION MOVEMENT}

In order to understand the behavior of pollutants in the environment, it is essential to understand the forces which control reactions. By far, the most important aspect of wetland systems is the saturated soil conditions. Waterlogged soils typically are low in oxygen, which can result in significant changes in chemical speciation and thus mobility. Following a discussion of the nature of soils in waterlogged conditions, some general factors which influence mobility will be considered. In particular, the difference between fixation and adsorption will be discussed.

Soil Types in the Affected Areas. A summarization of the major soil types in the affected areas is needed to assist in determining the chemical transitions that will occur. Soils have variable clay mineralogies and reactivities. This will result in different cation exchange capacities. As a result, there will be significant differences in the way contaminants migrate through different soils.

Soils in the affected areas are saturated. While many of them look highly organic, they are not (Table 3). The transition from wetland to upland soils is abrupt and generally follows topographic boundaries. A list of soils found in the affected areas as identified by SRS soil surveys is in Table 3. According to Hawkins (1971), kaolinite is the dominant mineral in clay fractions found in the stream beds at the SRS. This indicates that kaolinite will be the mineral fraction in the affected areas. Kaolinite clays are not susceptible to shrink/swell caused by wetting and drying cycles. Cation exchange capacity is pH dependent (Bohn et al., 1985). At low $\mathrm{pH}$, some kaolinite dominated soils may develop a negative cation exchange capacity. This is in effect, a positive anion exchange capacity.
Wagram Soil Study. The Wagram sandy loam, which is present in the contaminated areas at SRS, was previously included in a study on the contribution of the soil to the migration of trace elements (Fuller et al., 1976; Korte, et al., 1975; Korte et al., 1976). Quantity leached and the rate of leaching was determined for several leaching agents. Four types of agents were selected to represent a wide range of possible leachates. Aqueous $\mathrm{H}_{2} \mathrm{SO}_{4}$ was used to represent moderate acidity. Industrial leachate was represented by $\mathrm{AlCl}_{3} \mathrm{FeCl}_{3}$, a very strongly buffered acid and a readily oxidizable leachate. Deionized water and a natural landfill leachate were also used in the study. Pertinent information for the Wagram sandy loam is summarized in Table 4.

All soils were shown to be most susceptible to leaching by $\mathrm{AlCl}_{3} \mathrm{FeCl}_{3}$, the strongest acid. In acid soils, the most mobile constituents were aluminum, iron, nickel, and zinc. Chromium was also mobile, but tended to be retained in soils with high concentrations of free iron and manganese oxides. Breakthrough time, the time until constituents appear in the effluent, was shortest for chromium, mercury, nickel, and zinc. All of these elements show large increases in effluent concentration levels. The breakthrough time for lead was delayed, but concentrations increased sharply upon appearance. The primary factor controlling the release of trace metals under leaching appear to be the total metal present and total manganese and iron oxides. Cation exchange capacity and $\mathrm{pH}$ appear to be unimportant in determining the quantity of metal that a given soil may contribute. Quantity is most likely to be a function of the mineral structure of a soil. However, the major loadings of ions such as sodium at the SRS sites exacerbates 
Table 3: Summary of Soil Types Found in Affected Areas Near F- and H-Area Seepage Basins of the Savannah River Site

\begin{tabular}{|c|c|c|c|c|c|c|}
\hline \multirow[t]{2}{*}{ Soil property } & \multicolumn{6}{|c|}{ Soil type } \\
\hline & Altany & Fluvaquent & Fuquay & Pickney & V-A Complex & Wagram \\
\hline CLAY \% & $1-10$ & $2-16$ & $2-35$ & $2-10$ & $10-45$ & 1.35 \\
\hline \multicolumn{7}{|c|}{ Note: Values represent a range of depths, lowest values occur at the surface } \\
\hline MOIST BULK & 1.40 & 1.30 & $1.40-$ & 1.20 & $1.30-$ & 1.35- \\
\hline DENSITY & 1.70 & 1.65 & 1.70 & 1.60 & 1.95 & 1.75 \\
\hline SOI. pH & $4.5-6.0$ & $4.5-5.5$ & $4.5-6.0$ & $3.6-6.5$ & $3.6-6.0$ & $4.5-6.0$ \\
\hline ORGANIC MATIER \% & $1-2$ & 1.5 & $0.5 \cdot 2$ & $3-15$ & $<1$ & $0.5 \cdot 2$ \\
\hline \multicolumn{7}{|l|}{ FLOODING } \\
\hline frequency & none & frequent & none & frequent & none & none \\
\hline duration & - & brief & - & long & - & - \\
\hline months & - & Nov-Apr & - & Nov-Jun & - & - \\
\hline \multicolumn{7}{|l|}{ HIGH WATER TABLE } \\
\hline depth (ft) & $1.0-2.5$ & $0-1.0$ & $4.0-6.0$ & $+1-1.0$ & 26 & $>6$ \\
\hline kind & appanent & apparent & perched & apparent & - & - \\
\hline months & Dec-Mar & Nov-Apr & Jan-Mar & Nov-Apr & & \\
\hline
\end{tabular}

Soil Name

Family or Higher Taxanomic Group

Albany loamy sand $0.6 \%$ slopes

Fluvaquents

Fuquay loamy sand $2-6 \%$ slopes

Pickney sands

Vaucluse-Ailey Complex 6-10\% slopes

Loamy, siliceons, thermic, Arencic Hapludults, Ultisols

Fluvaquents

Loamy, siliceous, thermic, Arenic Plinthic Paleudults, Ultisol

Sandy, siliceous, thermic, Anceptisol

Wagram sand 2-6\% slopes

Fine - loamy, siliceous, thermic. Typic, hapludults, Ultisol

Loamy, siliceus, thermic, Arenic Paleuquits, Ultisol 
the availability and mobility of ions due to overloading of mineral exchange sites. The extent of mobility and migration of soil borne pollutanis varies considerably, depending on the chemical nature of the aqueous vehicle.

Table 4: Soil characteristics of a Wagram sandy loam, order Ultisol

Soil pH

Cation exchange capacity

Eulk density

Sand

Silt
4.2

$2 \mathrm{meq} / 100 \mathrm{~g}$

$1.89 \mathrm{~g} /$ cubic centimeter

$88 \%$

$8 \%$

$4 \%$

\section{Affects of Flooding on Soils}

The affects of flooding on soils were reviewed by Ponnamperumma (1972). The absence of oxygen is perhaps the most important feature of flooded soils. Oxygen is quickly depleted from most soils, with time ranging from as little as a few hours to several days following saturation. With water occupying the pore spaces, diffusion is up to 10,000 times slower than when the pore spaces are air filled. This situation quickly leads to anaerobic or reducing conditions, in which elements other than oxygen serve as electron acceptors. Nitrogen is the first element to be reduced, with nitrate $\left(\mathrm{NO}_{3}{ }^{-}\right)$typically becoming molecular nitrogen $\left(\mathrm{N}_{2}\right)$ or nitrous oxide $\left(\mathrm{N}_{2} \mathrm{O}\right)$. The next four elements to be reduced are, in order, manganese, iron, sulfur, and carbon. Table 5 shows the oxidized and reduced forms of the major electron acceptors as well as their solubilities. Electrochemical changes which take place in submerged soils include: alteration of the redox potentials; changes in $\mathrm{pH}$; changes in specific conductance and ionic strength; and shifts in mineral equilibrium.

Reduction potential is a measure of electron pressure in a system. Systems with high potentials have large amounts of free electrons and elements are in the oxidized state. Systems with low potentials have very few free electrons and elements are in the reduced state. Soils with large amounts of nitrates ( $>275 \mathrm{ppm}$ ) will retain positive potentials for several weeks after flooding. Soils that are low in organic matter $(<1.5$ percent) or high in manganese ( $>0.2$ percent) maintain positive potentials even after several months. At the SRS, the high levels of nitrate are a good indication that the soils are not highly reduced, although this could also result from continued input of nitrate from groundwater seepage. 
Table 5: Oxidized and reduced forms of the major electron acceptors Element Oxidized Reduced

\begin{tabular}{lll} 
Oxygen & $\mathrm{O}_{2}$ volatile & $\mathrm{H}_{2} 0$ soluble \\
Nitrogen & $\mathrm{NO}_{3}$ soluble & $\mathrm{N}_{2}$ volatile \\
Manganese & $\mathrm{Mn}(\mathrm{IV})$ insoluble & $\mathrm{Mn}(\mathrm{II})$ soluble \\
Iron & $\mathrm{Fe}(\mathrm{III})$ insoluble & $\mathrm{Fe}(\mathrm{II})$ soluble \\
Sulfur & $\mathrm{Sulfate} \mathrm{soluble}$ & Sulfide insoluble \\
Carbon & $\mathrm{CO}_{2}$ soluble & $\mathrm{CH}_{4}$ volatile \\
\hline
\end{tabular}

Changes in $\mathrm{pH}$ due to flooding generally result in trends toward neutrality. Alkaline soils exhibit a decrease in $\mathrm{pH}$ due to an increase in $\mathrm{CO}_{2}$. Organic matter magnifies the decrease in $\mathrm{pH}$ from sodic and calcareous soils. Acid soils exhibit an increase in $\mathrm{pH}$ primarily as a function of iron content. The unbalanced equation

$$
3 \mathrm{Fe}(\mathrm{OH})_{3}+\mathrm{H}^{+}+\mathrm{e}^{-}=\mathrm{Fe}_{3}(\mathrm{OH})_{8}
$$

shows that hydrogen ions are taken up in relation to the iron content. Since most soils contain more $\mathrm{Fe}(\mathrm{III})$ than any other oxidant, the increase in $\mathrm{pH}$ in flooded acid soils can largely be attributed to the reduction of iron (Ponnamperumma, 1972).

Specific conductance increases immediately after submergence, reaches a maximum, and then declines to a stable level. The initial increase is generally due to the release of $\mathrm{Fe}$ (II) and Mn(II). Precipitation of iron and manganese results in a decline after some peak value is reached. Neutral and alkaline soils start out with high values and reach levels exceeding $2 \mathrm{mmhos} / \mathrm{cm}$. The large values are due to the initial dissolution of calcium carbonate. Strongly acid soils have low initial values, reach 2 to 4 mmhos $/ \mathrm{cm}$ and then decline sharply. In soils that are nonsaline, the highest values are 4 to $5 \mathrm{mmhos} / \mathrm{cm}$ and are obtained in soils with low cation exchange capacity and high in organics.

Changes in speciation are shown in stability diagrams. Stability diagrams allow general analysis of species found for a wide range of potentials and $\mathrm{pH}$. A stability diagram for iron and manganese is shown in Figure 20 (Collins and Boul, 1970). With low electron pressure, high $\mathrm{pH}$ is required for precipitation. With high electron pressure, low $\mathrm{pH}$ is required for precipitation. While these diagrams can be useful, Dragun (1988) warns that stability diagrams are constructed for specific conditions, and if those conditions are not met, misuse of the diagrams can lead to mistakes in predicting speciation. However, this $\mathrm{pH}$ EH diagram does give an index to the available iron and manganese species under various redox and hydrogen ion conditions. This information can be used to estimate the general availability of these ions under SRS conditions.

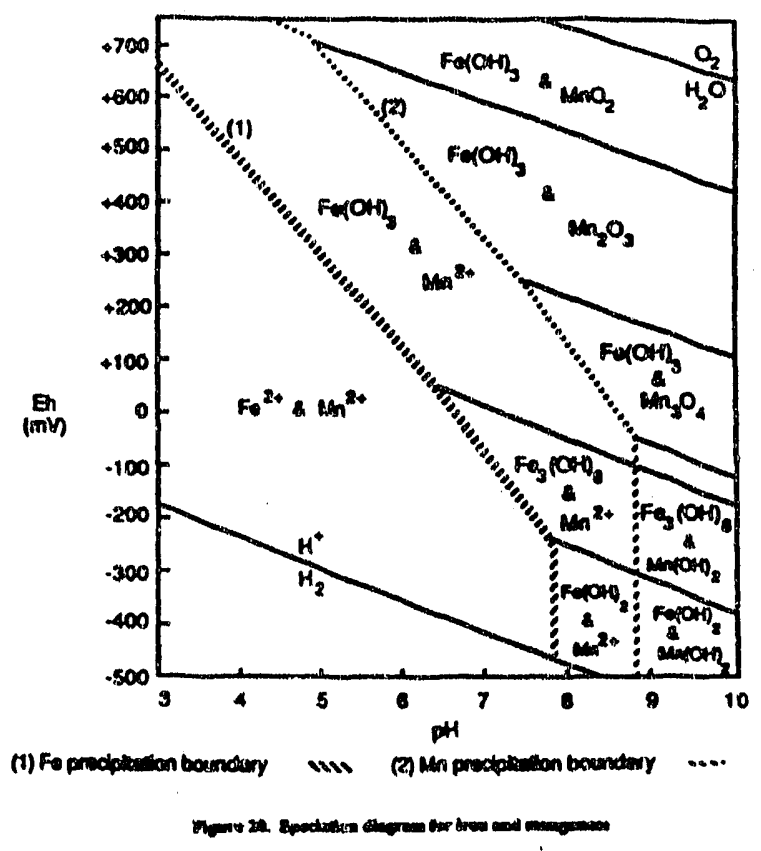




\section{A REVIEW OF FACTORS RELATING TO THE DISTRIBUTION, TRANSPORT, AND BIOAVAILABILITY OF SELECTED CONTAMINANTS IN THE SOIL MATRIX}

Sodium The accumulation of dispersive cations such as sodium affect soil processes such as stability and hydraulic conductivity. Shainberg and Letey (1984) describe how high levels of salinity cause flocculation of clay particles. Clay plates have overlapping negative ionic atmospheres. This electrical repulsion means that work must be done in order to bring the plates closer together. As the ionic atmosphere becornes compressed, overlap of the electrical fields is decreased. This results in less work being needed to bring the plates together. Increases in salt concentration will result in more positive charges being adsorbed onto the clay surface. Consequently, the repulsive forces between particles will decrease. In a stable suspension, particles that collide due to Brownian motion will separate because of these repulsive forces. When a salt is added to the solution, the particles stick together upon collision, forming flocs. Generally, this will cause a decrease in permeability, until some critical salt concentration is reached, at which point permeability will increase. Keren and Shainberg (1984) reported that sodium saturated kaolinite was partially flocculated at $\mathrm{pH}=4$, and was completely deflocculated by the addition of small amounts of $\mathrm{NaOH}$. Deflocculation can result in impermeability to water and air.
Sodium hazard is defined by the sodium adsorption ratio (SAR)

$$
\mathrm{SAR}=\left[\mathrm{Na}^{+}\right] /\left\{\left[\mathrm{Ca}^{2+}+\mathrm{Mg}^{2+}\right] / 2\right\}^{1 / 2}
$$

where all of the concentrations are in millimoles of charge per liter; and the exchangeable sodium percentage (ESP)

$$
\mathrm{ESP}=100 * \mathrm{ESR} /(1+\mathrm{ESR})
$$

where ESR is the exchangeable sodium ratio. The exchangeable sodium ratio is

$$
\mathrm{ESR}=\mathrm{K}_{\mathrm{G}} * \mathrm{SAR}
$$

where $\mathrm{K}_{\mathrm{G}}$ is the Gapon exchange constant. The Gapon exchange constant can be determined from

$$
\mathrm{K}_{\mathrm{G}}=\left[\mathrm{Ca}^{2+}\right]^{1 / 2}(\mathrm{NaX}) /\left[\mathrm{Na}^{+}\right]\left(\mathrm{Ca}_{1 / 2} \mathrm{X}\right)
$$

where brackets refer to concentrations in solution and the values in parenthesis aie equivalent fractions. Technically, t'se Gapon equation should make use uf ion activities. However, the ratio sf activities and the ratio of concentrations is quite similar, and thus is an aderiuate substitute (Shainberg and Letey, 1954). Table 6 shows the traditional classification of salt affected soils.

Table 6: Traditional classification of salt affected soils (adapted from Bohn et al., 1985)

\begin{tabular}{llll} 
Normal & Saline & Sodic & Salino-Sodic \\
\hline EC $<400 \mu \mathrm{S} / \mathrm{cm}$ & $\mathrm{EC}>400 \mu \mathrm{S} / \mathrm{cm}$ & $\mathrm{ESP}>15 \%$ & EC $>400 \mu \mathrm{S} / \mathrm{cm}$ \\
$\mathrm{ESP}<15 \%$ & & ESP $>15 \%$ \\
\hline
\end{tabular}


Using the soil water data from 1988, F-Area has an ESP of 67 percent and specific conductivity of $1300 \mu \mathrm{S} / \mathrm{cm}$ (micro-siemens per centimeter). This standing surface water only gives an estimate of ESP, but probably underestimates it. This would classify the soil as saline-sodic. H-Area has an ESP of 37 percent and specific conductivity of 237 $\mu \mathrm{S} / \mathrm{cm}$. This would classify the soil as sodic. Sodic soils are normally associated with alkaline conditions. The acidic conditions at F-Area may somewhat ameliorate the sodic effects on soil structure but probably not to a sufficient degree to offset all dispersion. Inspection shows these soils to be similar to but less severely affected than true sodic soils.

Nitrate Nitrate transformations are largely the result of microbiological conversions. Oxygen is the key to nitrate formation and lack of oxygen is the key to denitrification. Mineralization of organic nitrogen in submerged soils stops at the ammonia stage because of the lack of oxygen to carry the process via nitrite to nitrate. Ponnamperumma (1972) showed that nitrate undergoes two transformations in submerged soils. First, assimilation occurs with the incorporation of products into cell substances. Second, dissimulation or nitrate reduction occurs when nitrate acts as an alternative to oxygen as an electron acceptor. (Gambrell and Patrick, 1978) suggest that little nitrate is assimilated in reduced soils. First, the nutritional requirements for nitrogen by obligate and facultative anaerobic organisms in reduced soils is usually less than for electron acceptors. Second, reduced soils and sediments usually have an adequate supply of ammonium $\mathrm{N}$, which is the preferred nitrogen source for nutritional purposes. In addition, (Bowden, 1987) suggests that many wetland species have evolved in the absence of nitrate, and thus are unable to assimilate it. Anaerobic decomposition is considerably slower than aerobic decomposition. Ponnamperumma (1972) reports that the rate of denitrification follows first order kinetics:

$$
\mathrm{dC} / \mathrm{dt}=-\mathrm{kC}
$$

with highest velocities near neutral and low velocities for acid soils.

Redman and Patrick (1965) reported that nitrate reduction rates are closely related to clay content and organic matter. Increases in clay content and organic matter seem to increase the rate of nitrate reduction. Also, nitrate should serve to retard the rate of decrease in redox potential. This is due to the fact that nitrate can be used as an alternative to oxygen as an electron acceptor.

In the F-and $\mathrm{H}$-Areas, high levels of nitrate may be responsible for maintaining soils that are not highly reduced. The high nitrate levels may have several explanations. The clay fractions of the soils are dominated by kaolinite, which is capable of adsorbing significant quantities of nitrate at the $\mathrm{pH}^{\prime} \mathrm{s}$ that dominate. The microbial activity in these soils may be low due to toxicant stress, leading to slow rates of reduction. These factors, coupled with the very large inputs of nitrate, can explain why nitrate levels are so large in the affected areas.

Manganese Increases in manganese ion concentration in soil solution is one of the first measurable effects of reducing conditions. Gotoh and Patrick (1972) report that at $\mathrm{pH}=5$, greater than 90 percent of manganese is in the water soluble or exchangeable form, with approximately one half being water soluble. This might be expected, since at low $\mathrm{pH}$, hydrogen and aluminum can drive manganese from exchange sites. Typical solution concentrations in anaerobic acidic and leached soils may be close to 200 to 300 micrograms per gram (Coughtrey and Thorne, 1983).

Displacement of manganese may also be caused by several other factors. Khattak et al. (1989) have confirmed earlier works which report that sodium, calcium, and nitrate displace $\mathrm{Mn}$ (II) from soil solid surfaces by cation exchange reactions. They also report that the salt solution has no effect on the reduction of manganese. Donner et al. (1982) investigated the interactions of nickel, copper, and cadmium with soil manganese in saline solutions. They concluded that nickel, copper, and cadmium in sodium salt solutions resulted in increased manganese 
concentration in the effluent. It was postulated that heavy metal sorption resulted in the release of hydrogen ions and manganese. In individual tests with these metals, there was a slight decrease in the effluent $\mathrm{pH}$. The most notable decrease in $\mathrm{pH}$ was for copper, which may be accounted for by greater copper sorption on the soil surface.

In the experiments by Khattak et al. (1989), changes in salinity also have an affect on the amount of manganese released. The efficiency of manganese release increases with salinity. It appears that salt solution can keep $\mathrm{H}^{+}$ions in solution.

Cadmium Cadmium is always found in the +2 valence state in water, thus redox potentials have little direct effect on species form (Callahan et al., 1979). At $\mathrm{pH}=5$, the water soluble component is 60 to 70 percent, the percentage being considerably lower in oxidized environments (Sposito, 1981). Of the water soluble cadmium, 72 percent is present in the free ion form (Sposito, 1981). The effect of raising $\mathrm{pH}$ is to reduce the percentage of water soluble and exchangeable forms. The presence of large amounts of sulfur in reduced environments will result in precipitation as insoluble sulfides.

Adsorption with colloidal hydrous ions of iron and manganese primarily occurs in oxidized environments, yet low levels of oxygen in the study area suggest that it is not a major controlling mechanism. Adsorption onto silica and aluminum oxides is strongly $\mathrm{pH}$ dependent. Desorption occurs below the pH range of 6 to 7 (Callahan et al., 1979).

Binding capacity of organic colloids is reduced by low pH levels. However, humic acids and other natural complexing agents are capable of maintaining cadmium in a bound form at a pH as low as 3.0 (Callahan et al., 1979). Major pools of cadmium adsorption are onto exchange sites and complexation with insoluble organics. Adsorption increases as the proportion of exchange sites initially holding $\mathrm{Na}^{+}$ions is increased.

Copper Copper is most likely to be mobile under acidic conditions (Leckie and Davis, 1979). Solubility is dramatically decreased under reducing conditions. Speciation will be determined by the complexing ligands since adsorption behavior is strongly dependent upon the type and concentration of organic and inorganic ligands. With knowledge of the solid phase solubilities, one might be able to predict which phase will dominate under specific conditions. Difficulties will arise because of uncertainties in the solubility data and lack of reliable hydrolysis constants (Leckie and Davis, 1979).

Availability to plants is affected by the degree to which copper is bound to exchange sites. Copper is strongly held on inorganic and organic exchange sites and organic matter complexes. Displacement from exchange sites is most affested by the hydrogen ion concentration, but can be induced by organic ligands or detergents (Pickering, 1979). The effect of soil water content is not well understood, with changes in mobility depending on soil type (Thornton, 1979).

Chromium Mobility and bioavailability are related to the form, either hexavalent or trivalent. Most forms of $\mathrm{Cr}$ (III) in soil are low in solubility. Chromium (VI) is readily leached or taken up by plants. Total chromium content usually ranges from 100 to $20 \mathrm{wg}$ per kg (Coleman, 1988). Because oxidation strikingly increases the mobility of chromium in soil and oxidation is kinetically fast compared with reduction, reduction can be considered to occur at an indefinitely later time and perhaps at some point far from the place of origin. This is especially true for low organic soils, since organic matter is necessary to reduce $\mathrm{Cr}(\mathrm{VI})$ (Bartlett and Kimble, 1976b). Cr (VI) is toxic as an oxidizing agent, and it is this form which should be considered, in contrast with total chromium. However, this conclusion is challenged by some (Schroeder and Lee, 1975).

Chromium (III). Chromium (III) is oxidized to $\mathrm{Cr}(\mathrm{VI})$ under "ery specific circumstances. Oxidized manganese serves as a link between $\mathrm{Cr}$ (III) and atmospheric $\mathrm{O}_{2}$. It appears that $\mathrm{MnO}_{2}$ regulates the rate of oxidation, even when the quantity of 
manganese far exceeds that necessary to oxidize all of the chromium (Shroeder and Lee, 1975). ('ations such as calcium and magnesium o:cupying sorption sites on $\mathrm{MnO}_{2}$ particles may inhibit this reaction, which would suggest that chromium must be sorbed onto the $\mathrm{MnO}_{2}$ in order to be oxidized (Shroeder and Lee, 1975).

Since Cr(III) can be found in close association with $\mathrm{Al}$ (III) and $\mathrm{Fe}$ (III), much of the past research on aluminum may be useful in predicting chromium solubility. At $\mathrm{pH}>5$, it precipitates quickly due to the formation of insciluble hydroxides or oxides, especially $\mathrm{Cr}(\mathrm{OH})_{3}$ (Callahan, 1979). Precipitation is apparently complete at $\mathrm{pH}=5.5$ (Bartlett and Kimble, 1976a). At ph $<5$, ionic $\mathrm{Cr}$ (III) will be the most bioavailable form, however the most mobile forms by diffusion or mass flow will be soluble organics and dispersable colloidal inorganic hydroxy polymers, silicates, carionates, and clay materials. Low weight molecular acids such as citrate and gallic acid will increase the mobility of $\mathrm{Cr}$ (III).

Chromium (VI). $\mathrm{Cr}(\mathrm{VI})$ is soluble and mobile, and behaves similarly to nitrate released slowly by mineralization. It does not accumulate in humid region subsoils. It is always found in aqueous solution as a component of a complex ion (Callahan, 1979). The dichromate ion $\mathrm{Cr}_{2} \mathrm{O}_{7}^{-2}$ is found in waters with $\mathrm{pH}$ well below that found in natural waters (Callahan, 1979). In the presence of aluminum, $\mathrm{Cr}(\mathrm{VI})$ was precipitated as the $\mathrm{pH}$ increased above 4 to 5 , completely insoluble between pH 6-7 and increasingly soluble above $\mathrm{pH} 8$ (Bartlett and Kimble, 1976b).

$\mathrm{Cr}(\mathrm{VI})$ can be reduced by $\mathrm{Fe}(\mathrm{II})$ and dissolved sulfides (Shroeder and Lee, 1975; Callahan, 1979). However, the reduction by $\mathrm{Fe}(\mathrm{II})$ is significantly interfered with because $\mathrm{Fe}(\mathrm{II})$ is also oxidized by $\mathrm{O}_{2}$. While sulfides are also oxidized by $\mathrm{O}_{2}$, the rate is much slower and interference dos: not become a significant problem.

Effects on Soil. So:i respiration in nonorganic soils was decreased at $100 \mathrm{mg}$ of $\mathrm{Cr}$ (III) per kilogram of soil. However, 10 $\mathrm{mg}$ of $\mathrm{Cr}(\mathrm{VI})$ per kilogram of soil decreased respiration in nonorganic solls. Five millimoles of $\mathrm{CrCl}_{3}$ per kilogram of soil inhibited nitrification, although the form of chromium was not determined. As low as $0.5 \mathrm{mg} / \mathrm{L}$ in soil solution and $5 \mathrm{mg} / \mathrm{kg}$ in soil have been reported to reduce plant growth.

Mercury Mercury occurs in three valance states; $\mathrm{HgO}_{3} \mathrm{Hg}_{2}{ }^{2+}$; and $\mathrm{Hg}^{2+}$ which is found in chloride and hydroxide complexes. The normal concentration range in soils is 10 to 50 nanograms per gram, with average content based on grain size; sand $13 \mathrm{ng} / \mathrm{g}$, silt 29 $\mathrm{ng} / \mathrm{g}$, clay $94 \mathrm{ng} / \mathrm{g}$. In moderately oxidizing environments above $\mathrm{pH}=5$, the predominate species will be elemental (Callahan, 1979). In moderately reducing environments, precipitation with sulfides will occur.

The fate of mercury in the environment is very complex. Leaching occurs only in trace amounts and only in soils that are acidic. At high concentrations where significant fractions may be free in solution, reduction is probably mediated by humus. Methylation increases the mobility of mercury, and accumulation is counteracted by volatilization and demethylation.

Effect of Chlorides. Chlorides could be a more important factor in solubility than has been previously considered (Hahne and Kroontje, 1973). Concentration of $\mathrm{Cl}^{-}$ions at $3.5 \mathrm{ppm}$ increases solubility of $\mathrm{Hg}(\mathrm{OH})_{2}$ by 55 times and $\mathrm{HgS}$ by 408 times. Mercury (II) competition between hydroxy and chloride complexes takes place over a much wider $\mathrm{pH}$ and chloride ion concentration than zinc, cadmium, or lead (Hahne and Kroontje, 1973).

Effect of Organic Matter. Mercury complexed by organics will be retained as long as conditions are such as to keep the organic matter precipitated. If conditions change, the organics may pass into solution. Removal by leaching is thus more likely in acid soils. Removal by evaporation is more likely in neutral and alkaline soils.

Biologic Effects. Effects are in proportion to the available amounts, hence effects can be 
expected to be greatest with decreasing contents of clay, humus and probably $\mathrm{pH}$. Organic mercurials in the range of 10 to 100 $\mu \mathrm{g} / \mathrm{g}$ will significantly interfere with carbon and nitrogen mineralization. Soils low in colloidal material can be sterilized by $5(X)$ $\mu \mathrm{g} / \mathrm{g}$. Increasing soil concentration will gradually change populations of soil microbes, so as to favor those species that tolerate mercury.

\section{SOIL CHEMISTRY SYNTHESIS}

It would appear that several factors are causing stress near F- and H-Area Seepage Basins.

The salt and sodium content of the soils have produced conditions which are not typical for the area. As was shown earlier, F-Area has an exchangeable sodium percentage of 67 percent and the H-Area ESP is 37 percent. Both of these values are well over the danger mark of 15 percent. A partially flocculated soil creates a ituation in which roots are growing in solut..n. Roots growing in solution take up wa:er soluble ions much more readily when oumpared to roots in a soll matrix. Based on field observations and our data, this ap ars to be the case, particularly at F-Area. This creates a chronic stress condition.

Heavy metals (manganese, codmium, and zinc) along with aluminum are $\mathrm{e}$ vated at F-Area. These metals are also elevared at $\mathrm{H}$ Area, but to a lesser degree. The heavy metals may be causing toxicity directly. The heavy metals may, on the other hand, be acting as an intermediary for other agents. An example of this would be manganese toxicity. Toxic levels of manganese may be brought into solution by heavy metal adsorption onto soil surfaces. The next section examines the plant toxicity literature to evaluate these candidate stressors.

\section{CHEMICAL TOXICITY TO NYSSA SYLVATICA VAR. BIFLORA}

\section{INTRODUCTION}

The focus of this section is to determine the effects of various chemicals on Nyssa sylvatica var. biflora. Unfortunately, there are few studies assessing chemical effects on Nyssa sylvatica or on other wetland tree species. Therefore, the literature search was shifted to assessing the effects of various chemicals on other moist-site species such as Acer rubrum, Acer Saccharum, and Liriodendron tulipifera. These two species have a diffuse porous wood structure, which is the same as Nyssa sylvatica var. biflora (Panshin and deZeeuw, 1980). While the results of studies on species other than Nyssa $S P$. cannot be used to identify the exact chemical stressor, they can be used to:

- Limit the list of candidate stressors

- Indicate where research should be focused

The effects of chemicals on trees can be divided into two categories. First, a chemical may be directly toxic to the species. Iany of the chemicals analyzed by the $S$ annah River Site are necessary for plant rowth. However, when these chemicals reacl certain concentrations, they become directly toxic to the plants. Other chemicals, such as cadmium, are toxic at very low concentrations. Second, chemicals can have indirect effects on plant growth. Various chemicals can interfere with the uptake, synthesis, and function of elements both essential and non-essential. These types of interactions generally result in nutrient deficiencies and disruption of physiological processes such as photosyntiesis, respiration, enzyme synthesis, etc.

\section{METHODS}

To determine the tolerance of vege :ation to specific levels of ions, a computerized literature search, using the BRS After: ours database system, was conducted. The biological and environmental databases were searched for literature describing Nussa 
svlvatica's tolerance to various chemicals. The preliminary studies gave an indication of the most likely stressors. However, since the trees died ten years before any chemical analysis was done, all possible parameters were investigated.

The initial search did not provide much useful information. Therefore, the focus of the search shifted to locate information on trees that are found in habitats similar to that of Nyssa sylvatica. Where it was possible, only hardwood species were used as indicators of chemical stress. However, some data on conifer species were used to fill in the areas where data were sparse.

The data obtained in the literature search was then compared to the site specific data. This allowed the elimination of chemicals that had no known effect on either Nyssa sylvatica or other tree species.

\section{SUMMARY OF LITERATURE FINDINGS}

\section{Aluminum}

Direct Toxicity. Solution concentrations of alurnifinm that can result in toxicity range from $100 \mu \mathrm{g} / \mathrm{L}$ to $3.2 \times 10^{4} \mu \mathrm{g} / \mathrm{L}$ depending upon the species (Bowen, 1979). Accumulation of aluminum occurs primarily in roots. However, as the root system is injured, accumulation of aluminum in shoots occurs (Andersson, 1988). The physiological and biochemical effects of aluminum toxicity in roots include: (1) disturbance of mitosis resulting in abnormal root growth, inhibition of nucleic acid synthesis, and reduction of DNA activity; (2) alteration of the structure and function of root membranes resulting in a reduction of permeability to water and nutrients; (3) reduction of root respiration which provides the energy needed for maintenance of structures and synthesis of compounds necessary for production of new structures.

A study by Thornton et al. (1986) determined the effects of applying aluminum in concentrations of $0,2.7 \times 10^{3}, 8.9 \times 10^{3}$, $1.35 \times 10^{4} 1.62 \times 10^{4}, 2.7 \times 10^{4}, 4.05 \times$ $10^{4}$, and $5.4 \times 10^{4} \mu \mathrm{g} / \mathrm{L}$ to Acer saccharum seedlings that were grown in nutrient solutions (pH 4). The growth (measured as total dry weight accumulation) of Acer Saccharum was stimulated by the $2.7 \times 10^{3}$ and $1.35 \times 10^{4} \mu \mathrm{g} / \mathrm{L}$ aluminum concentrations. The growth stimulation was due to small amounts of aluminum acting as polyvalent cations that protect the roots from $\mathrm{H}^{+}$ion damage when the solutions are highly acidic (pH 4) (Thornton, 1986). Thus, low aluminum concentrations remove the inhibitory effect caused by low pH's causing Acer saccharum to respond favorably. However, higher concentrations of aluminum override this beneficial effect and toxicity occurs. In this experiment, growth was reduced by 25 percent at aluminum concentrations of $2.7 \times 10^{4} \mu \mathrm{g} / \mathrm{L}$, by 44 percent at aluminum concentrations of $4.05 x$ $10^{4} \mu \mathrm{g} / \mathrm{L}$ and by 54 percent at aluminum concentrations of $5.4 \times 10^{4} \mu \mathrm{g} / \mathrm{L}$. Thornton et al. (1986) also determined that aluminum concentrations greater than $1.62 \times 10^{4} \mu \mathrm{g} / \mathrm{L}$ resulted in an exponential decline in growth with increasing aluminum concentrations.

Thornton et al. (1986) found no differences between root morphology and elongation in the control and those seedlings treated with aluminum. Differences in shoot elongation were readily apparent but there were no other visual symptoms of aluminum toxicity (Thornton et al., 1986). The lack of root response and other visual symptoms of aluminum toxicity might be due to the length of the experiment which only lasted 45 days.

Another study by Thornton et al. (1987) determined the effects of aluminum on Picea rubens seedlings grown in solution culture. Solutions (full strength media) were maintained at $\mathrm{pH} 4$ and were amended with the following aluminum concentrations: 0 , $1.35 \times 10^{4}, 5.4 \times 10^{4}$, and $8.1 \times 10^{4} \mu \mathrm{g} / \mathrm{L}$. A second experiment was conducted to determine the effect that nutrient concentrations had on aluminum phytotoxicity. The second experiment reduced nutrient concentrations by five (onefifth strength media) and were amended with the following aluminum concentrations: 0 , $6.75 \times 10^{3}, 1.35 \times 10^{4}, 2.7 \times 10^{4}$, and $5.4 \times$ $10^{4} \mu \mathrm{g} / \mathrm{L}$. In both media types, Picea rubens growth was completely inhibited at $5.4 \times 10^{4}$ 
$\mu \mathrm{g} / \mathrm{L}$. The $6.75 \times 10^{3} \mu \mathrm{g} / \mathrm{L}$ concentration reduced root elongation by 16 percent in the full strength media and by 11 percent in onefifth strength media. The same aluminum concentration significantly reduced shoot elongation. Shoot elongation was reduced by 15 percent in the full strength media and by 29 percent in the one-fifth strength media. Total dry weight of Picea rubens was significantly reduced by $6.75 \times 10^{3} \mu \mathrm{g} \mathrm{Al} / \mathrm{L}$ and the reduction was greater in the one-fifth strength media. This suggests that aluminum toxicity was more severe in the one-fifth media. This is because the one-fifth media had a lower ionic strength which increased the activity of the aluminum ions (Thornton et al., 1987).

\section{Indirect Affects of Aluminum}

Interference with Calcium Calcium is necessary for cambial growth which is important in conducting water from the roots to the crown, storing carbohydrates, and fighting infection. Interference of aluminum with calcium occurs when the molar ratio of aluminum to calcium is greater than one (Shortle and Smith, 1988). In the study by Thornton et al. (1986), an aluminum concentration of $2.7 \times 10^{3} \mu \mathrm{gL}$ significantly reduced the calcium tissue levels of Acer saccharum. Root calcium concentrations were reduced by 50 percent, stem calcium concentrations were reduced by 13 percent, and leaf calcium concentrations were reduced by 17 percent.

Interactions with Manganese Roy et al. (1988) found that the presence of aluminum can cause manganese to accumulate in roots. While low concentrations of manganese are essential for iron availability and the activation of enzymes, manganese toxicity can occur at solution concentrations ranging from $1 \times 10^{3}$ to $1 \times 10^{5} \mu \mathrm{g} / \mathrm{L}$ (Bowen, 1979).

Interference with Potassium Aluminum competes with potassium for root absorption sites which can lead to potassium deficiency within the plant (Roy et al., 1988). Potassium deficiency can hinder the translocation of carbohydrates, nitrogen metabolism, and the function of stomata (Kramer and Kozlowski, 1979).

When low amounts of aluminum $(2.7 \mathrm{x}$ $10^{3}-1.4 \times 10^{4} \mu \mathrm{g} \mathrm{Al} / \mathrm{L}$ ) were applied to Acer saccharum, potassium tissue concentrations increased slightly. At higher aluminum concentrations $\left(5.4 \times 10^{4} \mu \mathrm{g} \mathrm{Al} / \mathrm{L}\right)$, the foliar potassium content was reduced by 16 percent (Thornton et al., 1986).

Interference with Magnesium Magnesium is an important constituent of chlorophyll as well as being involved in the action of enzyme systems and maintaining the integrity of ribosomes (Kramer and Kozlowski, 1979). In Acer sp., low concentrations of aluminum elevated magnesium concentrations. However, higher aluminum concentrations reduced magnesium levels (Roy et al., 1988). In the study on Acer saccharum, stem, leaf, and root magnesium levels were not stimulated by low aluminum concentrations. At higher aluminum levels $\left(5.4 \times 10^{4} \mu \mathrm{g} \mathrm{Al} / \mathrm{L}\right)$ the foliar magnesium content was reduced by 50 percent (Thornton et al., 1986).

Interfersuce with Iron Aluminum treatments have reduced iron concentrations in roots and shoots of some plants while increasing the concentrations in other plants. Aluminum can also interfere with the reduction of $\mathrm{Fe}^{3+}$ to $\mathrm{Fe}^{2+}$ which is essential for iron metabolism (Roy et al., 1988). Iron is an essential component of chloroplast proteins and respiratory enzymes and maintains the integrity of ribosomes (Kramer and Kozlowski, 1979).

Interactions with Copper A luminum competes with copper for binding sites on the root surface. In potatoes, elevated aluminum caused accumulation of copper in the roots. In sorghum, copper content of roots and tops decreased (Roy et al., 1988). Small quantities of copper are needed for synthesis of certain enzymes (Kramer and Kozlowsi, 1979).

Interference with Phosphorus Aluminum precipitates phosphorus on the root surfaces reducing translocation of phosphorus to tops. 
Aluminum can also interfere with phosphorus metabolism (Roy et al., 1988). Phosphorus is a constituent of phospholipids and nucleoproteins. The phosphorous bonds of many phosphate groups in these compounds provide the chief medium for energy transfer within the plants (Kramer and Kozlowski, 1979). Low levels of aluminum $\left(2.7 \times 10^{3}\right.$. $1.4 \times 10^{4} \mu \mathrm{g} \mathrm{AVL}$ ) applied to Acer saccharum increased the tissue concentrations of phosphorus. However, the highest aluminum application $\left(5.4 \times 10^{4} \mu \mathrm{g} \mathrm{Al} / \mathrm{L}\right)$ decreased the foliar phosphorus concentration by 66 percent (Thornton et al., 1986).

\section{Nitrate}

Nitrate uptake by plants may increase metal cation uptake, especially aluminum. This is due to the fact that cells must maintain elecroneutrality. However, if nitrate uptake occurs as an exchange of $\mathrm{OH}^{*}$, aluminum activity may decrease since $\mathrm{OH}^{-}$increases $\mathrm{pH}$ (Andersson, 1988). Godbold et al. (1987) grew Picea abies seedlings in nutrient solutions containing $1.35 \times 10^{4} \mu \mathrm{g} \mathrm{Al} / \mathrm{L}$ and one of the following nitrate concentrations: $2.07 \times 10^{4} \mu \mathrm{g} / \mathrm{L}$ or $4.12 \times 10^{4} \mu \mathrm{g} / \mathrm{L}$, or 6.12 $x 10^{4} \mu \mathrm{g} / \mathrm{L}$. The study determined the effect of these concentrations on root growth. The greatest inhibition of root growth occurred for seedlings grown in the $6.12 \times 10^{4} \mu \mathrm{g}$ $\mathrm{NO}_{3} / \mathrm{L}$ and $1.35 \times 10^{4} \mu \mathrm{g} \mathrm{Al} / \mathrm{L}$. solutions. However, no strong interactions between aluminum and nitrate could be found.

The same study also grew Picea abies seedlings in solutions containing only nitrate. The greatest stimulation of root growth occurred in solutions containing $6.2 \times 10^{4} \mu \mathrm{g}$ $\mathrm{NO}_{3} / \mathrm{L}$.

\section{Manganese}

Manganese is an essential micronutrient that can be toxic when present in large quantities (Epstein, 1972). Manganese is necessary for the synthesis of chlorophyll, the activation of enzymes, nitrogen metabolism, and the light reactions of photosynthesis (Radwan et al., 1979). Keeley (1979) analyzed the root tissues of
Nyssa sylyatica one year old seedlings and found that normal manganese root concentrations are $965 \mu \mathrm{g} / \mathrm{g}$ dry-weight.

Manganese toxicity varies according to species. Toxicity symptoms include: marginal and/or interveinal chlorosis and root mortality (Hoyle, 1972). In an experiment by Hoyle (1972), Betula alleghaniensis seedlings were grown in solutions amended with $0.5,5.0,50,5 \times 10^{2}, 5 \times 10^{3}, 2.5 \times$ $10^{4}, 5 \times 10^{4}, 1 \times 10^{5}, 2 \times 10^{5}$, and $4 \times 10^{5}$ $\mu \mathrm{g} \mathrm{Mn} / \mathrm{L}$. At concentrations greater than $5 \times$ $10^{3} \mu \mathrm{g} / \mathrm{L}$ both stem and leaf weight declined. Concentrations greater than $1 \times 10^{5} \mu \mathrm{g} / \mathrm{L}$ resulted in root death. The study concluded that solution concentrations greater than $2.5 \mathrm{x}$ $10^{4} \mu \mathrm{g} \mathrm{Mn} / \mathrm{L}$ and foliage concentrations greater than $1.3 \times 10^{3} \mu \mathrm{g} \mathrm{Mn} / \mathrm{g}$ were toxic (Hoyle, 1972).

\section{Cobalt}

Normal foliar concentrations of cobalt range between 1 and $3 \mu \mathrm{g} / \mathrm{g}$ dry-weight. However, Nyssa sylvatica can accumulate up to $27.2 \mu \mathrm{g} / \mathrm{g}$ with no apparent adverse affects. The majority of cobalt is found in the xylem of the trees. Cobalt moves upward in Nyssa sylvatica and remains mobile for at least three growing seasons (Thomas, 1975).

\section{Phosphorus}

In drained conditions, application of phosphorus benefited growth of Nyssa sylvatica seedlings. However, under flooded conditions, application of phosphorus may have been detrimental due to a reduction in concentration of calcium, magnesium, zinc, and iron and a reduction in height and root length. However, water potential in flooded conditions was increased when phosphorus was applied. Under drained conditions, phosphorus reduces water potential (Hook et al., 1983).

\section{Sedium and Chloride}

Since most studies on the effects of salts on vegetation look at both sodium and chloride together, these ions will be 
discussed together. Sodium has no known physiological function in most higher plants. Only certain halophytes require sodium as a nutrient and can withstand large concentrations of the chemical (Epstein, 1972; Kramer and Kozlowski, 1979). Sodium can be directly toxic to plants, and it can also reduce the plant's uptake of water and other essential nutrients. When sodium is present in the soil solution in large quantities, it changes the osmotic potential and the ionic balance of the soil solution (Kramer and Kozlowski, 1979).

Unlike sodium, chloride plays a necessary role in physiological processes. Chloride is required in small quantities by plants in the water-splitting step of photosynthesis (Kramer and Kozlowski, 1979). Halophytic vegetation tends to take up larger quantities of chloride than other plants, but excessive uptake of chloride can be toxic (Epstein, 1972). Visual symptoms of salt injury to trees include: growth reduction; leaf scorch and curling; leaf drop; stem dieback; decline in vigor; and death (Hanes et al., 1976).

Hanes et al. (1976) performed field experiments on various species of decidous seedlings. Seedlings were planted on a Sassafras fine sandy loam soil located in the coastal plain region of Virginia and were treated with various concentrations of either $\mathrm{NaCl}$ or $\mathrm{CaCl}_{2}$. The salt was applied during the winter months and plant measurements were taken during the summer. The sodium concentration in the soils subjected to $\mathrm{NaCl}$ ranged from $1.86 \times 10^{2} \mu \mathrm{g} \mathrm{Na} / \mathrm{g}$-soil to 1.53 $x 10^{3} \mu \mathrm{g} \mathrm{Na} / \mathrm{g}$-soil. Of all the species, Liriodendron tulipifera was the most sensitive to the salt treatments. Liriodendron tulioifera seedlings treated with either $\mathrm{NaCl}$ or $\mathrm{CaCl}_{2}$, had similar foliar concentrations of sodiumn. These foliar concentrations were considered normal and ranged from $1.5 \times 10^{2} \mu \mathrm{g} \mathrm{Na} / \mathrm{g}$ dry weight to $4 \times 10^{2} \mu \mathrm{g} \mathrm{Na} / \mathrm{g}$ dry weight. Thus, it was concluded that the damage caused by the salt applications was not due to sodium but chloride.

The chloride levels in the soils ranged from $3.72 \times 10^{2} \mu \mathrm{g} \mathrm{Cl} / \mathrm{g}$-soil to $2.73 \times 10^{3}$ $\mu \mathrm{g} \mathrm{Cl} / \mathrm{g}$-soil for the $\mathrm{NaCl}$ treatments and from
$4.56 \times 10^{2} \mu \mathrm{g} \mathrm{Cl} / \mathrm{g}$-soil to $2.01 \times 10^{3} \mu \mathrm{gCl} / \mathrm{g}$ soil for the $\mathrm{CaCl}_{2}$ treatments. In the $\mathrm{NaCl}$ treatments, severe damage to Liriodendron tulipifera was observed when the soil chloride concentration was $8.42 \times 10^{2} \mu \mathrm{g} / \mathrm{g}$ soil. At this concentration, the seedlings had severe leaf scorch, moderate defoliation, and minor limb death. The foliar chloride concentration was $6.14 \times 10^{3} \mu \mathrm{g} / \mathrm{g}$ dry weight. All of the Liriodendron tulipifera seedlings died when the soil chloride concentration was $1.81 \times 10^{3} \mu \mathrm{g} / \mathrm{g}$-soil. In the $\mathrm{CaCl}_{2}$ treatments, the Liriodendron tulipifera seedlings died when the soil chloride concentration was $2.01 \times 10^{3} \mathrm{\mu g} / \mathrm{g}$ soil. In addition, it was noted that injury increased as the chloride concentrations of the foliage increased, but when the foliage was severely burnt or dead, the chloride foliar concentrations declined. Thus, chloride is readily leached from dead or dying foliage and analysis of this foliage may lead to erroneous conclusions (Hanes et al., 1976).

The other species studied in this investigation had varying responses to the treatments. Gleditsia triacanthos var. inermis was very tolerant of all salt treatments. Betula pendula, Acer saccharum, and Cercis canadensis were considered moderately tolerant to salt treatments; they withstood low levels of salts, but many died when exposed to the higher salt levels (Hanes et al., 1976). Fraxinus pennsylyanica was as susceptible to salt treatments as Liriodendron tulipifera: injury occurred at the lowest salt levels and most of the seedlings died at the higher salt treatments (Hanes et al., 1976). Thus, the injury to plants caused by salts depends upon both the amount of salt in the soil and the plant species.

Foster and Maun (1978) determined the effects of $\mathrm{NaCl}$ and $\mathrm{CaCl}_{2}$ on four year old Thuja occidentalis growing in a greenhouse potting soil mixture. After eight days of application, salt concentrations greater than $1.5 \mathrm{M}$ injured the seedlings. In the soils treated with $\mathrm{NaCl}$, the soil sodium concentration was $4.8 \times 10^{2} \mu \mathrm{g} / \mathrm{g}$-soil, the foliar sodium concentration was $3 \times 10^{3} \mu \mathrm{g} / \mathrm{g}$ dry weight, the soil chloride conceniration was $5.6 \times 10^{2} \mu \mathrm{g} / \mathrm{g}$ - soil, and the foliar 
chloride concentration was $1.64 \times 10^{4} \mu \mathrm{g} / \mathrm{g}$ dry weight. In the soils treated with $\mathrm{CaCl}_{2}$, the soil sodium concentration was not significantly different from the control ( 20 $\mu \mathrm{g} / \mathrm{g}$-soil) and the soil chloride concentration was $1.27 \times 10^{3} \mu \mathrm{g} / \mathrm{g}$-soil. Symptoms included: yellowing of leaf tips that eventually became necrotic; sharp demarcation between healthy and necrotic tissues; and yellowing at bases of secondary and tertiary branches. These injuries to the foliage are related to ion or osmotic effects (Foster and Maun, 1978).

At concentrations of $2.0 \mathrm{M} \mathrm{NaCl}$ and $2.5 \mathrm{M} \mathrm{CaCl}_{2}$, the root tips were killed. In the $\mathrm{NaCl}$ teatment the sodium soil concentration was $5.2 \times 10^{2} \mu \mathrm{g} / \mathrm{g}$-soil, the root sodium concentration was $1.03 \times 10^{4} \mu \mathrm{g} / \mathrm{g}$ dry weight, the soil chloride concentration was $1.15 \times 10^{3} \mu \mathrm{g} / \mathrm{g}$-soil, and the root chloride concentration was $9.9 \times 10^{3} \mu \mathrm{g} / \mathrm{g}$ dry weight. In the $\mathrm{CaCl}_{2}$ treatment, the soil chloride concentration was $3.87 \times 10^{3} \mu \mathrm{g} / \mathrm{g}$-soil. The symptoms of injury on roots include: browning of root tips, loss of root hairs, development of red color, and eventual drying and complete browning of root sy stem (Foster and Maun, 1978).

The study concluded that foliar sodiurn concentrations greater than $3 \times 10^{3} \mu \mathrm{g} / \mathrm{g}$ dry weight and foliar chloride levels greater than $8 \times 10^{3} \mu \mathrm{g} / \mathrm{g}$ dry weight were toxic to Thuja occidentalis (Foster and Maun, 1978).

It was noted in the Hanes et al. (1976) study that salt injury differs among various species. Since Thuia occidentalis is a conifer, it is necessary to compare the salt sensitivity of Thuja occidentalis to hardwood species. A study by Lumis et al. (1973) compared the sensitivity of various trees exposed to aerial drift of deicing salts. Various species were ranked according to their sensitivity: a ranking of one indicated that the plant was not sensitive, while a ranking of five indicated that the plant was highly sensitive. Thuja occidentalis had a sensitivity ranking of three to four, while hardwood species found in similar habitats to Nyssa sylvatica had sensitivity rankings between two and three. It thus appears that
Thuia occidentalis is more sensitive to salts than Nyssa sylvatica.

\section{Sulfate}

Sulfur is required in large quantities by plants. It is a macronutrient and for normal growth to occur, foliage concentrations should approximate $2 \times 10^{3} \mu \mathrm{g} / \mathrm{g}$ (Kramer and Kozlowski, 1979). Sulfur is an important constituent of many plant enzymes and amino acids. Sulfate is the form of sulfur that is readily available for plant uptake (Epstein, 1972).

Even though this chemical is needed in great quantities, there have been studies that indicate too much sulfate in the substrate can have adverse affects on plant growth. In a study by Richardson et al. (1983), water enriched with $1.5 \times 10^{5} \mu \mathrm{g} / \mathrm{L}$ of sulfate was pumped onto experimental plots located within a Northern Florida floodplain forest. The study determined the species which experienced stress as a result of the sulfate enrichment. Stress was measured by counting the number of red, yellow, and green leaves on the forest floor, the number of seedlings, and the number of stressed trees. The authors considered the trees as stressed if "leaves were wilting, changing color, drooping, or if the plant was obviously dead." The tree species that appeared most sensitive to sulfate enrichment were Nyssa sylvatica var. biflora and Liquidambar styraciflua. Symptoms of stress were apparent within one year of initiation of the study.

The study did not report how excessive sulfate can damage plants but did suggest that the production of sulfide in anaerobic sediments can create further toxic problems. The study was also designed in such a manner that the impact would be visible but not cause permanent damage (Richardson et al., 1983). However, this study is still useful in this situation because it gives an indication of the level at which stress can occur, thus allowing us to assume that higher sulfate levels will result in further damage to the plants. The study is also usefui because the species studied is the species of primary concern in this situation, thus no inference is 
necessary to determine Nyssa sylvatica var. biflora's sensitivity to sulfate. A final important aspect of this study is that it was conducted in the field and that the stress effects were measured on mature trees.

\section{Conper}

Copper is considered a micronutrient, that is: it is required only in minute quantities. Its primary function is in protein synthesis (Epstein, 1972). A study by Stone and Timmer (1975) conducted on the Tantramar Copper Swamp, New Brunswick, determined the normal copper concentrations for Acer rubrum foliage, roots, and twigs. Normal foliage concentrations ranged from 4.0-12.7 $\mu \mathrm{g} / \mathrm{g}$ dry weight, normal twig concentrations ranged from 1.6 to $8.0 \mu \mathrm{g} / \mathrm{g}$ dry-weight, and normal root concentrations were $10 \mathrm{lg} / \mathrm{g}$ dry-weight.

Like many other nutrients, too much copper can be toxic (Kramer and Kozlowski, 1979). A study by Heale and Ormrod (1972) found that the stem diameter increase of Acer rubrum was reduced by 41 percent when the seedlings were grown in a solution containing $4 \times 10^{3} \mu \mathrm{g} \mathrm{Cu} / \mathrm{L}$. When the seedlings were grown in a solution containing $2 \times 10^{4} \mu \mathrm{g} \mathrm{Cu} / \mathrm{L}$ stem diameter increase was 78 percent less than growth in the solution containing less than $1 \times 10^{2} \mu \mathrm{g}$ $\mathrm{Cu} / \mathrm{L}$. Other species (Cornus stolonifera, and Lonicera tatarica) grown in these solutions exhibited growth reductions greater than the reductions observed in Ace rubrum while Pinus resinosa's growth was not affected. This observation indicates that there is species variability with relation to copper toxicity.

Visible symptoms of copper injury to Acer rubrum were also evaluated in Stone and Timmer's (1975) study. In both the $4 x$ $10^{3} \mu \mathrm{g} \mathrm{Cu} / \mathrm{L}$ and the $2 \times 10^{4} \mu \mathrm{g} \mathrm{Cu} / \mathrm{L}$ solutions, the foliage exhibited moderate to severe interveinal chlorosis and slight leaf tip blackening. Visible injury occurred to Acer rubrum roots in the solution containing $2 x$ $10^{4} \mu \mathrm{g} \mathrm{Cu} / \mathrm{L}$. The root injury observed included: discoloration of root tissue; reduction in the number of lateral roots; and the few lateral roots present were thickened, stunted, and had enlarged tips (Stone and Timmer, 1975).

The accumulation of copper in the leaves of Acer rubrum associated with each copper treatment in the Stone and Timmer (1975) study was not significantly different from the control. However, accumulation in both the stem and roots were significantly higher. The $4 \times 10^{3} \mu \mathrm{g} \mathrm{Cu} / \mathrm{L}$ treatment resulted in a stem concentration of $2.51 \times 10^{2} \mu \mathrm{gCu} / \mathrm{g}$ (control stem $=35.9 \mu \mathrm{g} \mathrm{Cu} / \mathrm{g}$ dry weight) and the $2 \times 1 \mathrm{C}, \mathrm{Cu} / \mathrm{L}$ treatment had a total stem accumulat $n$ of $4.1 \times 10^{2} \mu \mathrm{g} \mathrm{Cu} / \mathrm{g}$ dry weight. In Acer rubrum, the roots had the highest copper accumulation. The $4 \times 10^{3} \mu \mathrm{g}$ $\mathrm{Cu} / \mathrm{L}$ treatment resulted in a root concentration of $1.39 \times 10^{3} \mu \mathrm{g} \mathrm{Cu} / \mathrm{g}$ (control root $=73.7 \mu \mathrm{g} \mathrm{Cu} / \mathrm{g}$ dry weight) and the $2 *$ $10^{4} \mu \mathrm{g} \mathrm{Cu} / \mathrm{L}$ treatment had a total root accumulation of $1.52 \times 10^{3} \mu \mathrm{g} \mathrm{Cu} / \xi$ dry weight.

\section{Lead}

Lead is not necessary for plant growth. Most of the lead found in plants is confined to the roots with little or no accumulation in the leaves and stems (Davis and Barnes, 1973). Soil concentrations of lead ranging from 20 to $200 \mu \mathrm{g} / \mathrm{g}$ are considered normal (Davis and Barnes, 1973).

Davis and Barnes (1973) determined lead concentrations that were harmful to both Pinus taeda and Acer rubrum. Lead was applied in the following concentrations: 0 , $4.14 \times 10^{4} \mu \mathrm{g} / \mathrm{L}, 2.07 \times 10^{5} \mu \mathrm{g} / \mathrm{L}, 4.14 \times$ $10^{5} \mu \mathrm{g} / \mathrm{L}$, and $1.04 \times 10^{6} \mu \mathrm{g} / \mathrm{L}$. Significant reductions in the height and the stem and root dry weights of both species were observed at concentrations of $2.07 \times 10^{5} \mu \mathrm{g} \mathrm{Pb} / \mathrm{L}$. The growth reductions of the lead treatments were greater and more significant than the fluoride treatments. The visual sympioms of lead injury for Pinus taeda include: needles that were progressively smaller with increasing lead concentrations, needle color was milky green, needle necrosis at the highest lead leveis, and a blackened and reduced root system. As lead concentrations increase ", Acer rubrum leaves became redder (due to an 
increase in anthocyanin) and were cast earlier (Davis and Barnes, 1973).

In the lead treatments, the only plant response affected by soil type was the root/shoot ratio. The reduction in root/stoot ratio was greater on the Georgeville silt loam than the Whitestore sandy loam (Davis and Barnes, 1973).

Davis and Barnes (1973) cite another study where five year old spruce seedlings that were watered with $1 \times 10^{6} \mu \mathrm{g} \mathrm{Pb} / \mathrm{L}$ produced no detrimental effects while their own study resulted in damage at lead concentrations of $2.07 \times 10^{5} \mu \mathrm{g} / \mathrm{L}$. Davis and Barnes (1973) attribute this discrepancy to the difference in plant age. They conclude that younger plants may be more sensitive to lead treatments than older plants.

\section{Nickel}

Nickel is another element that has no known function in plant growth processes (Kramer and Kozlowski, 1979). References cited by Bowen (1979) indicate that nickel phytotoxicity occurs when solution concentrations are between $5 \times 10^{2} \mu \mathrm{g} \mathrm{Ni} / \mathrm{L}$ and $2 \times 10^{3} \mu \mathrm{g} \mathrm{Ni} / \mathrm{L}$.

A study by Heale and Ormrod (1982) determined the effects of solutions containing $2 \times 10^{3} \mu \mathrm{g} \mathrm{Ni} / \mathrm{L}$ and $1 \times 10^{4} \mu \mathrm{g} \mathrm{Ni/L}$ on Acer rubrum, Cornus stolonifera, Lonicera tatarica, and Pinus resinosa. Only in Lonicera tatarica did nickel significantly retard stem enlargement and dry weight increase.

However, all species did exhibit some visual symptoms related to nickel injury. For all species, the $2 \times 10^{3} \mu \mathrm{g} \mathrm{Ni} / \mathrm{L}$ treatment resulted in slight to moderate foliage chlorosis and discoloration of root systems. At $1 \times 10^{4} \mu \mathrm{g} \mathrm{Ni} / \mathrm{L}$ Lonicera tatarica's foliage exhibited the greatest damage with moderate to severe chlorosis, severe leaf drop, and severe inward rolling of leaf tips and margins. Acer rubrum and Cornus stolonifera had slightly greater foliage damage at nickel concentrations of $1 \times 10^{4}$ $\mu \mathrm{g} / \mathrm{L}$ than $2 \times 10^{3} \mu \mathrm{g} / \mathrm{L}$ and included an increase in the degree of chlorosis along with light to moderate purpling and blackening of leaves. The foliage damage to Cornus stolonifera was more severe than Acer rubrum. Pinus resinosa's foliage was damaged the least at nickel concentrations of $1 \times 10^{4} \mu \mathrm{g} / \mathrm{L}$. Damage to the root systems of all species at the higher nickel concentration included: discoloration, reduction in the number of lateral roots, stunting of lateral roots, thickening of roots, and enlargement of lateral root tips (Heale and Ormrod, 1982).

The study also combined treatments of nickel and copper. It was found that nickel root accumulation was less when copper was present than when it was absent. Acer rubrum and Cornus stolonifera stem and leaf accumulations of nickel when copper was present either remained the same or were smaller than when copper was absent. Lonicera tatarica's stems and Pinus resinosa's needles had higher nickel concentrations when $1 \times 10^{4} \mu \mathrm{g} \mathrm{Ni} / \mathrm{L}$ and $2 \times$ $10^{4} \mu \mathrm{g} \mathrm{Cu} / \mathrm{L}$ than when only $1 \times 10^{4} \mu \mathrm{g} \mathrm{Ni} / \mathrm{L}$ was applied. Thus, in some instances, the presence of copper appears to inhibit uptake of nickel (Heale and Ormrod, 1982).

\section{Cadmium}

Cadmium has no known function in biological systems and is readily taken up and accumulated by plants (Davies, 1987; Jastrow and Koeppe, 1980). Thus, relatively low concentrations of cadmium can have adverse affects on plant growth and other physiological processes. Some significant physiological effects of cadmium include the inhibition of electron transfer and interference with the synthesis of ATP (Jastrow and Koeppe, 1980).

The degree of toxicity depends upon cadmium concentration and duration of exposure. Buchauer (1973) found that tree foliage concentrations greater than $20 \mu \mathrm{g}$ $\mathrm{Cd} / \mathrm{g}$ are toxic. A study of vegetation and soil contamination near a Pennsylvania zinc smelter estimated the foliar cadmium concentrations of Nyssa sylvatica. The average Nyssa sylyatica foliar cadmium concentrations within $1 \mathrm{~km}$ of the smelter was $70 \mu \mathrm{g} / \mathrm{g}$. The soil cadmium concentration ranged from 900 to $1500 \mu \mathrm{g} / \mathrm{g}$. The vegetation in this region was sparse, 
"scrubby", and had foliage with interveinal chlorosis and marginal necrosis (Buchauer, 1973). Further away from the plant $(21 \mathrm{~km})$, foliar cadmium levels declined to approximately $1 \mu \mathrm{g} / \mathrm{g}$ (Buchauer, 1973). These cadmium levels should be used with caution since a large fraction of the reported foliar concentrations are due to atmospheric depositions.

Cadmium entering plants through the foliage appears to be less toxic than cadmium entering the plants via root uptake. For example, in one experiment Quercus rubra seedlings were grown both in "uncontaminated" soils ( 2 to $3 \mu \mathrm{g} \mathrm{Cd} / \mathrm{g}$-soil) and in "contaminated" soils $(10-500 \mu \mathrm{g}$ $\mathrm{Cd} / \mathrm{g}$-soil) (Buchauer, 1973). The seedlings grown in the "uncontaminated" soil were placed within $1 \mathrm{~km}$ of the smelter for two growing seasons and exhibited no toxic symptoms even though cadmium foliar concentrations was as high as $38 \mu \mathrm{g} / \mathrm{g}$. The seedlings grown in the "contaminated" soil remained inside the greenhouse and died before the end of the growing season. The dead seedlings had foliar cadmium levels ranging from 4 to $7 \mu \mathrm{g} / \mathrm{g}$ Buchauer (1973). Thus, the mode of cadmium entry into the plants is important: root uptake is more toxic than the entry of cadmium through foliage. Sopper and Kerr (1980) suggest that the highest tolerable cadmium tissue concentration is $3.0 \mu \mathrm{g} / \mathrm{g}$, and the above study on Quercus rubra seedlings appears to support this value.

A study by Lamoreaux and Chaney (1977) determined the effects of various cadmium concentrations on the growth and movement of water in eight week old Acer saccharinum seedlings. The authors germinated Acer saccharinum seeds, grew them for eight weeks in a sandy substrate treated with various concentrations of $\mathrm{CdCl}_{2}$ $2.5 \mathrm{H}_{2} \mathrm{O}$, and then harvested the seedlings to determine the leaf, stem, and root weights. Compared with the control, cadmium concentrations of $2.5 \mu \mathrm{g} / \mathrm{L}$ resulted in a 40 percent reduction in height, a 48 percent reduction in leaf weight, a 56 percent reduction in stem weight, and a 47 percent reduction in root weight. Higher concentrations of cadmium resulted in even greater growth declines. Visually, the seedlings appeared stunted and were wilting even though they were well-watered.

Since the seedlings showed signs of wilting, Lamoreaux and Chaney (1977) conducted a second experiment to determine the affect of cadmium on the movement of water within the plants. Compared with the control, $4.9 \times 10^{3} \mu \mathrm{g} \mathrm{Cd} / \mathrm{L}$ reduced the water conducting capacity of Acer saccharinum stems by 75 percent. The morphological conditions that reduced water conducting capacity were: (1) a significant decline in the amount of xylem tissue available for water conduction; (2) blockage of xylem elements by cellular debris and gums; and (3) reduction in the size of xylem elements. Cadmium interference with various plant enzyme systems caused the morphological deviations (Lamoreaux and Chaney, 1977).

A study by Mitchell and Fretz (1977) evaluated the concentrations of cadmium that were toxic to Acer rubrum seedlings (two to three years old) grown in nutrient solutions and a laboratory prepared soil. Visual symptoms of toxicity included: reduced root initiation; poor lateral root development; chlorosis; dwarfism; early leaf drop; wilting; and necrosis of current year's growth (Mitchell and Fretz, 1977). The seedlings grown in solution exhibited toxic symptoms when the cadmium concentration was equal to or greater than $8.0 \mu \mathrm{g} / \mathrm{L}$. At this cadmium level the leaf cadmium concentration was $22.8 \mu \mathrm{g} / \mathrm{g}$ and the root concentration was $446.9 \mu \mathrm{g} / \mathrm{g}$ (Mitchell and Fretz, 1977).

The seedlings grown in the laboratory prepared soil exhibited toxic symptoms when the theoretical soil concentration was $10.6 \mu \mathrm{g}$ $\mathrm{Cd} / \mathrm{g}$, the foliar cadmium concentration was $5.4 \mu \mathrm{g} / \mathrm{g}$, and the root concentration was 41.4 $\mu \mathrm{g} / \mathrm{g} \mathrm{Cd}$. The toxicity of seedlings grown in soil was less severe than that of the seedlings grown in nutrient solution (Mitchell and Fretz, 1977). Thus, plant accumulation of cadmium is lower when the plants are grown in soils than when grown in solution.

\section{Zinc}

Plants require minute amounts of zinc for various physiological processes (Kramer 
and Kozlowski, 1979; Van Hook et al., 1980). The primary role of zinc in plants is the regulation of plant auxin levels. Zinc is also important in the synthesis of amino acids and proteins, and acts as "either a constituent or an activator of several plant enzymes" (Epstein, 1972). Van Hook et al. (1980) cite that, in Nyssa sylvatica, foliage zinc concentrations of $40 \mu \mathrm{g} / \mathrm{g}$ are normal. However necessary zinc may be for normal plant growth, relatively low concentrations are toxic (Kramer and Kozlowski, 1979).

Symptoms of zinc toxicity are similar to symptoms of iron deficiency (Jordan, 1973). Leaf zinc toxicity symptoms appear as marginal and interveinal chlorosis, reduced leaf size, wilting, and eventual necrosis (Jordan, 1973, Mitchell and Fretz, 1977; Buchauer, 1973). Other symptoms include: reduction in growth, dwarfism, stunting and poor development of lateral roots, and reduced root initiation (Jordan, 1973; Mitchell and Fretz, 1977).

A study of vegetation and soil contamination near a Pennsylvania zinc smelter estimated the foliar zinc concentrations of Nyssa sylvatica. The average Nyssa sylvatica foliar zinc concentrations within $1 \mathrm{~km}$ of the smelter was $3000 \mu \mathrm{g} / \mathrm{g}$. The soil zinc concentration ranged from $5 \times 10^{4}$ to $8 \times 10^{4} \mu \mathrm{g} / \mathrm{g}$-soil. The vegetation in this region was sparse, "scrubby", and had foliage with interveinal chlorosis and marginal necrosis (Buchauer, 1973). Further away from the plant $(21 \mathrm{~km})$, foliar zinc levels declined to approximately 40 $\mu \mathrm{g} / \mathrm{g}$ (Buchauer, 1973). In the same study, an experiment was performed to determine the effect of zinc on Quercus rubra seedlings. The seedlings were grown both in "uncontaminated" soils $\left(1 \times 10^{2}-3 \times 10^{2} \mu \mathrm{g}\right.$ $\mathrm{Zn} / \mathrm{g}$-soil) and in "contaminated" soils $(2 \mathrm{x}$ $10^{3}-2 \times 10^{4} \mu \mathrm{g} \mathrm{Zn/L)} \mathrm{(Buchauer,} \mathrm{1973).}$ The seedlings grown in the "uncontaminated" soil were placed within $1 \mathrm{~km}$ of the smelter for two growing seasons and exhibited no toxic symptoms even though zinc foliar concentrations were as high as $2120 \mu \mathrm{g} / \mathrm{g}$. The seedlings grown in the "contaminated" soil remained inside the greenhouse and died before the end of the growing season. The dead seedlings had foliar zinc levels ranging from 400 to $500 \mu \mathrm{g} / \mathrm{g}$ Buchauer (1973). Thus, the mode of zinc entry into the plants is important: root uptake is more toxic than the entry of zinc through foliage.

A study by Jordan (1977) also used Quercus rubra seedlings to determine the effects of various zinc concentrations when the seedlings were grown in sand culture. In the experiments, seedlings treated with $1 \mathrm{x}$ $10^{6} \mu \mathrm{g} / \mathrm{L}$ of zinc for one week died. Zinc concentrations of $1 \times 10^{5} \mu \mathrm{g} / \mathrm{L}$ caused a reduction in growth, foliar chlorosis, and death after three to five months. Toxicity symptoms also appeared when the zinc concentration was as low as $1 \times 10^{4} \mu \mathrm{g} / \mathrm{L}$. Foliage of the seedlings contained 237 to 374 $\mu \mathrm{g} \mathrm{Zn/g}$ and, after five months, chlorosis was evident. Significant growth reductions were also apparent: $1 \times 10^{4} \mu \mathrm{g} \mathrm{Zn/L}$ caused a 61 percent reduction in root weight, a 63 percent reduction in stem weight, and a 39 percent reduction in leaf weight. The experiment also found that when cadmium and zinc occurred together, there was a significantly greater reduction in biomass, stem height, and blade length (Jordan, 1977).

A study by Mitchell and Fretz (1977) evaluated the concentrations of zinc that were toxic to Acer rubrum seedlings (two to three years old) grown in nutrient solutions and a laboratory prepared soil. Visual symptoms of toxicity included: reduced root initiation; poor lateral root development; chlorosis; wilting; and necrosis of leaf and stem tissue. The seedlings grown in solution exhibited toxic symptoms when the zinc concentration was greater than or equal to $25 \mu \mathrm{g} / \mathrm{L}$. At this zinc level, the leaf zinc concentration was $421.3 \mu \mathrm{g} / \mathrm{g}$ and the root concentration was $1427 \mu \mathrm{g} / \mathrm{g}$ (Mitchell and Fretz, 1977). The seedlings grown in the laboratory prepared soil exhibited toxic symptoms when the theoretical soil concentration was $82.5 \mu \mathrm{g}$ $\mathrm{Zn} / \mathrm{g}$ - soil, the foliar zinc concentration was $117.3 \mu \mathrm{g} / \mathrm{g}$, and the root concentration was $318.8 \mu \mathrm{g} \mathrm{Zn} / \mathrm{g}$. The toxicity of seedlings grown in soil was less severe than that of the seedlings grown in nutrient solution (Mitchell and Fretz, 1977). Thus, plant accumulation of zinc is lower when the plants are grown in soils than when grown in solution. 


\section{COMPARISON OF LITERATURE DATA TO OUR DATA}

\section{E-Area}

Aluminum. Table 7 compares the data found in the literature with the SRS data for the F-Area. The studies by Andersson (1988) report the solution concentrations of aluminum that are toxic to various Picea and Pinus species. These solution concentrations can be compared to the seepline data (Table 7). The 1987 and 1988 seepline values are substantially elevated compared to the literature data.

The aluminum studies on Acer saccharum show the aluminum concentrations of leaves and roots that are toxic (Table 7). The literature reports a root concentration of $4.0 \mathrm{x}$ $10^{3} \mu \mathrm{g} / \mathrm{g}$ as toxic; the SRS root analysis for Nyssa sylvatica var. biflora reports a concentration of $2.47 \times 10^{4} \mu \mathrm{g} / \mathrm{g}$. Thus, the site data is well above toxic levels reported in the literature. The foliage data for SRS is $116 \mu \mathrm{g} / \mathrm{g}$ while the toxic literature value for Acer saccharum is $100 \mu \mathrm{g} / \mathrm{g}$. The SRS foliage data is elevated compared to the literature data. The SRS levels can be considered toxic even if there is not as large a difference between the foliage data as there is in the root data. The roots tend to accumulate much more aluminum than the foliage and since the studies cited were only short term experiments, they may not have accumulated as much aluminum as the SRS trees that have been exposed to high aluminum for many years.

In Picea rubens, root aluminum concentrations of $1.35 \times 10^{4} \mu \mathrm{g} / \mathrm{g}$ resulted in death of the plant. This level is well below the level found in Nyssa sylvatica var. biflora and is further evidence of possible aluminum toxicity. 
Table 7. Comparison of literature data with F-Area Data

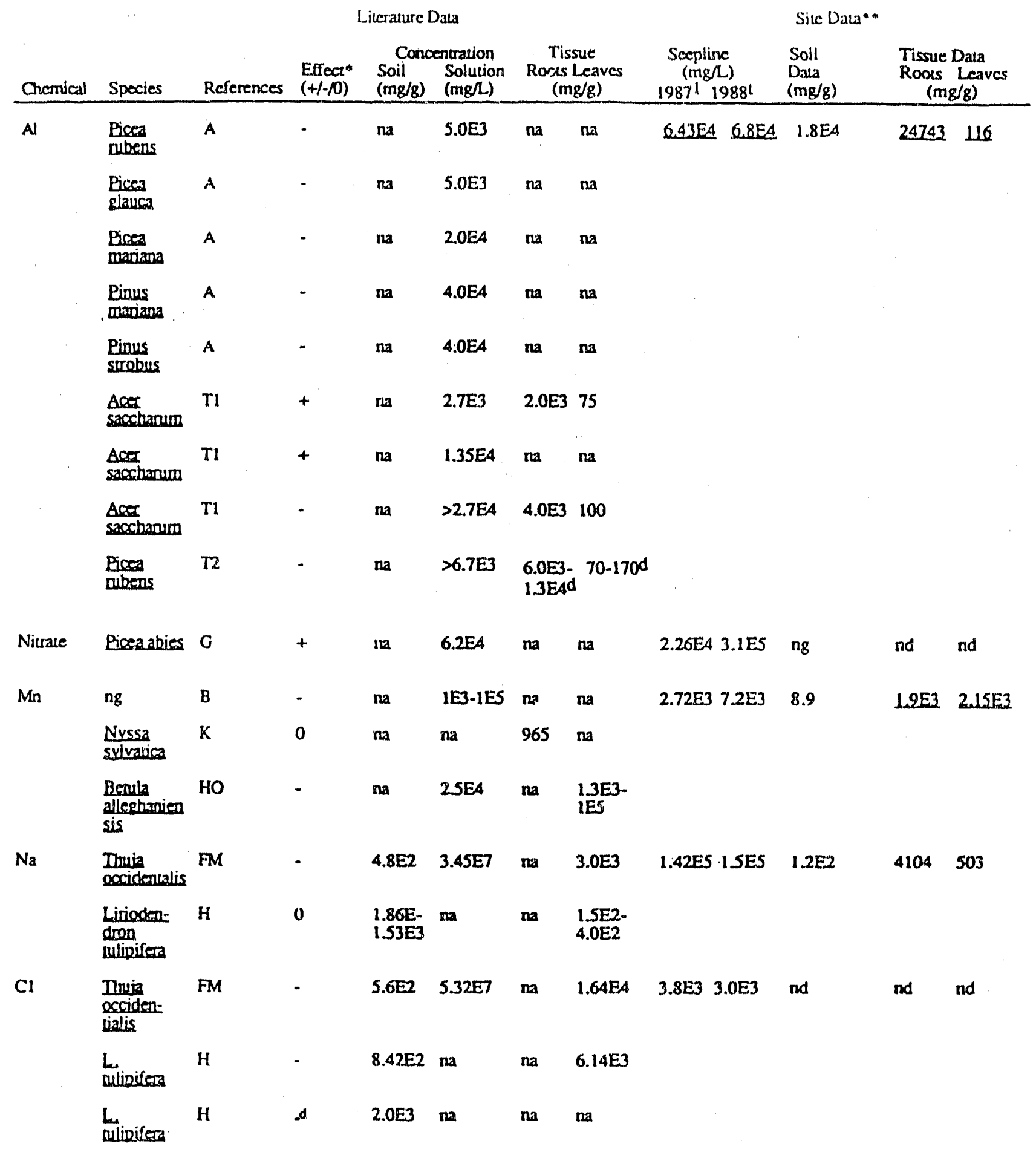


Table 7. Comparison of literature data with F-Area Data (Contd)

\begin{tabular}{|c|c|c|c|c|c|c|c|c|c|c|c|c|}
\hline \multirow{3}{*}{$\frac{\text { Cremical }}{\text { Sulfate }}$} & \multirow{3}{*}{$\begin{array}{l}\text { Species } \\
\begin{array}{l}\text { Nyssa } \\
\text { sylvatica }\end{array}\end{array}$} & \multirow{3}{*}{$\frac{\text { References }}{R I}$} & \multicolumn{3}{|c|}{ Literamure Data } & & & \multicolumn{5}{|c|}{ Site Dalia"* } \\
\hline & & & \multirow{2}{*}{$\begin{array}{c}\begin{array}{c}\text { Effoct } \\
(+/-10)\end{array} \\
\end{array}$} & \multicolumn{2}{|c|}{\begin{tabular}{ll}
\multicolumn{2}{c}{ Concentration } \\
Soil & Solution \\
$(\mathrm{mg} / \mathrm{g})$ & $(\mathrm{mg} / \mathrm{L})$
\end{tabular}} & \multicolumn{2}{|c|}{$\begin{array}{c}\text { Tissue } \\
\text { Roots Leaves } \\
(\mathrm{mg} / \mathrm{g})\end{array}$} & \multicolumn{2}{|c|}{$\begin{array}{c}\text { Secpline } \\
(\mathrm{mg} / 2) \\
19871 \quad 1988^{2} \\
\end{array}$} & \multirow{2}{*}{$\begin{array}{l}\begin{array}{l}\text { Soil } \\
\text { Dala } \\
\text { (mig/g) }\end{array} \\
\text { nd }\end{array}$} & \multicolumn{2}{|c|}{$\begin{array}{l}\text { Tissue Data } \\
\text { Roots Leaves } \\
\text { (mg/g) }\end{array}$} \\
\hline & & & & na & I.SES & na & na & $<1000$ & nd & & nd & nd \\
\hline \multirow[t]{2}{*}{$\mathrm{Cu}$} & $\begin{array}{l}\text { Acer } \\
\text { nabrum }\end{array}$ & $\mathbf{S T}$ & 0 & na & na & 10 & $4.0-12.7$ & 64 & 29 & $\angle \mathrm{DDL}$ & nd & nd \\
\hline & $\begin{array}{l}\text { Acen } \\
\text { nubrum }\end{array}$ & HO & $\cdot$ & na & $4.0 \mathrm{E} 3$ & $139 \mathrm{E} 3$ & na & & & & & \\
\hline \multirow[t]{2}{*}{$\mathrm{Pb}$} & ng & DB & 0 & $20-200$ & $<3.0 \mathrm{E} 3$ & ma & na & 3.3 & 7 & nd & nd & nd \\
\hline & 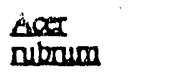 & $\mathrm{DB}$ & - & na & 2.07ES & na & $\mathbf{n a}$ & & & & & \\
\hline \multirow[t]{3}{*}{$\mathrm{Ni}$} & ng & $\mathbf{B}$ & 0 & ma & $\begin{array}{l}5.0 \mathrm{E} 2- \\
2.0 \mathrm{E} 3\end{array}$ & na & na & 50 & 86 & CIDL & nd & nd \\
\hline & $\begin{array}{l}\text { Acer } \\
\text { nubrom }\end{array}$ & DB & - & na & $1.0 \mathrm{EA}$ & na & na & & & & & \\
\hline & $\frac{\text { Lonicera }}{\text { Latarica }}$ & DB & - & па & $1.0 \mathrm{EA}$ & na & na & & & & & \\
\hline \multirow[t]{6}{*}{$\mathrm{Cd}$} & $\begin{array}{l}\text { Nyessa } \\
\text { sylvacica }\end{array}$ & BU & - & $\begin{array}{l}9.0 \mathrm{E} 2- \\
\text { ISE3 }\end{array}$ & na & na & 70 & 27 & $<5$ & nd & 3.64 & 0.35 \\
\hline & N.sylvatica & BU & 0 & $2.0-3.0$ & na & na & 1 & & & & & \\
\hline & Quentis nubas & BU & 0 & $2.0-3.0$ & $\mathrm{na}$ & na & na & & & & & \\
\hline & Q.nibra & BU & $-d$ & $10-500$ & $\mathbf{m a}$ & na & $4-7$ & & & & & \\
\hline & $\begin{array}{l}\text { Aces } \\
\text { sacetranimum }\end{array}$ & LC & - & ma & 2.5 & na & na & & & & & \\
\hline & A. nibrum & MF & " & ma & 8.0 & 446.9 & 22.8 & & & & & \\
\hline \multirow[t]{7}{*}{$\mathrm{Zn}$} & $\begin{array}{l}\text { Nussa } \\
\text { syluatica }\end{array}$ & $\mathbf{V H}, \mathbf{B U}$ & 0 & $\begin{array}{l}2.0 \mathrm{E} 3- \\
2.0 \mathrm{EA}\end{array}$ & na & na & 40 & $1.52 E_{2}$ & $3.0 \mathrm{E} 2$ & nd & nd & nd \\
\hline & N. sylvatica & BU & - & 5.0EA & ma & ma & $3.0 \mathrm{E3}$ & & & & & \\
\hline & Quercus nuber & BU & 0 & $\begin{array}{l}\text { 1.0E2-- } \\
3.0 \mathrm{E} 2\end{array}$ & na & na & $\mathbf{m a}$ & & & & & \\
\hline & Q.nubra & BU & d & $\begin{array}{l}\text { 2.0E3- } \\
2.0 E A\end{array}$ & na & $\mathrm{ma}$ & $\begin{array}{l}4.0 \mathrm{E} 2- \\
5.0 \mathrm{E} 2\end{array}$ & & & & & \\
\hline & Q.niba & J & - & ma & $1.0 \mathrm{E4}$ & ma & $\begin{array}{l}2.37 \mathrm{E} 2- \\
3.74 \mathrm{~F} 2\end{array}$ & & & & & \\
\hline & Q. mubrs & $J$ & d & $\mathbf{m}$ & $1.0 \mathrm{ES}$ & ma & $\mathrm{ma}$ & & & & & \\
\hline & Acectibnum & MF & - & $m$ & 25 & $1.43 \mathrm{E}$ & 3 4.21E2 & & & & & \\
\hline
\end{tabular}




\section{Table 7. Comparison of literature data with F-Area Data (Contd)}

nd not detected
ng data not given
na data not applicable

* Esfocts are ranked acconding to their effect on growth + means a positive grounth effect occurred; - means a negative growth effoct occurred, 0 - no growth effect occurred. For further details, consult the appropriate section in the literature review.

* All site tissue dala are reported for $\mathrm{N}$. sylvalica from the most severely stressed sites in the $\mathrm{F}$ Area. The soils and tissues were analyzed at Duke University. For those no analyzed at Duke, MetaTRACE and TMA values are usod. Áluminum values are Oxalate extraction data.

a indicates a $+1-10$ effect on pholosynuhesis rates

indicates a $+1-10$ effect on respiration rates

indicates a $+1-10$ effect on seedling death

1987 secpline data from Looncy a al. (1988)

1988 seepline data from Thermo Analytical. Inc. (TMA)

Andersson (1988)

T) Thomicon et al. (1986)

T2 Thomum et al. (1987)

SS Shorle and Smith (1988)

K Keeley (1979)

FM Foster ind Mam (1978)

RI Richardson et al. (1988)

ST Slone and Timmer (1975)

HO Hoale and Ormod (1972)

BW Braen and Weinstein (1985)

B Bowen (1979)

DB Davis and Barnes (1975)

H Hanes et al. (1976)

HB Holmes and Baker (1966)

$G$ Godbold e al. (1988)

BU Buchisuer (1973)

LC Lamoreaux and Chaney (1977)

MF Mitchell and Fretiz (1977)

VH Van Hook ex al. (1980)

J Jordan'(1975)

HO Hoyle (1972) 
Nitrate. The study on Picea abies reported that nitrate solution concentrations of $6.2 \mathrm{x}$ $10^{4} \mathrm{\mu g} / \mathrm{L}$ stimulated root growth. This value is slightly higher than the 1987 seepline data $\left(2.26 \times 10^{4} \mu \mathrm{g} / \mathrm{L}\right)$ and lower than the 1988 seepline data $\left(3.1 \times 10^{5} \mu \mathrm{g} / \mathrm{L}\right)$ reported at the F..Area site. No literature was found stating explicit nitrate levels that are injurious to trees. It is not known if the higher 1988 data is toxic to trees. Experiments should be done to determine the exact level that causes toxicity. Also, Picea abies is very different from Nyssa sylvatica and nitrate concentrations that stimulate Picea abies could be injurious to Nyssa sylvatica.

Manganese. The study by Keeley (1979) indicates that normal root manganese concentrations are $965 \mu \mathrm{g} \mathrm{Mn} / \mathrm{g}$-dry weight. The tissue analysis of Nyssa sylvatica is much higher than this $\left(1.9 \times 10^{3} \mu \mathrm{gg}\right.$, Table 7). Literature foliage concentrations considered toxic are $1.3 \mu \mathrm{g} \mathrm{Mn} / \mathrm{g}$ (Hoyle, 1972). The Nyssa sylvatica foliage at the $F$ Area is also much higher than the reported value (Table 7).

The literature data from Hoyle indicate that solution concentrations of $2.5 \times 10^{4} \mu \mathrm{g} / \mathrm{L}$ are toxic. The seepline data from the F Area are slightly lower than the literature data (Table 7). Since tree mortality occurred ten years ago, toxic levels of manganese could have been present. Also, the Nyssa sylvatica tissue concentrations are much higher than the literature values, therefore manganese is a possible cause of tree mortality.

Sodium. The study conducted on Thuia occidentalis showed that solutions containing greater than $3.45 \times 10^{7} \mu \mathrm{g} / \mathrm{L}$ of sodium in solution were toxic. The SRS seepline values are lower than the literature value (Table 7). The foliage sodium concentrations of Thuja occidentalis $\left(3 \times 10^{3} \mu \mathrm{g} / \mathrm{g}\right)$ are much higher than reported for Nyssa sylvatica var. biflora $(503 \mu \mathrm{g} / \mathrm{g})$. This difference could be due to the sampling of Nyssa sylvatica foliage late in the season, and since sodium is very water soluble much of it was lost, or it could be a species related difference with respect to translocation of chemicals.
The literature reported that foliar sodium levels ranging from 150 to $400 \mu \mathrm{g} \mathrm{Na} / \mathrm{g}$ were normal. At the SRS site, the foliar sodium levels of Nyssa sylvatica were slightly above the literature values. The use of foliage concentrations for comparison may not be appropriate since this chemical is easily lost from tissues.

The soil sodium concentrations $(1.86 \mathrm{x}$ $10^{2}-1.53 \times 10^{3} \mu \mathrm{g} \mathrm{Na} / \mathrm{g}$ ) that were reported as having no effect on Liriodendron tulipifera were only slightly above the soil levels $(1.2 \mathrm{x}$ $10^{2} \mu \mathrm{g} \mathrm{Na} / \mathrm{g}$ ) found at the SRS (Table 7). Since sodium is a very mobile element, the sodium concentrations may have been much higher ten years ago when the trees died than the current situation indicates. Therefore, sodium concentrations may have been high enough to cause mortality and further studies need to be conducted.

Chloride. The solution concentrations of chloride $\left(1.7 \times 10^{7} \mu \mathrm{g} / \mathrm{L}\right)$ that adversely affected Thuia occidentalis are higher than the seepline data $\left(1.42 \times 10^{5} \mu \mathrm{g} / \mathrm{L}\right)$ for the $F$ Area. This could lead to the conclusion that chloride is not a problem here. However, there is no soil or tissue chloride data from the F Area and these data should be obtained before specific conclusions are made about the toxicity of chloride to Nyssa sylvatica. Hanes et al. (1976) provided very useful data on the soil and foliar toxicity levels of chloride to Liriodendron tulipifera and it would be very useful to compare appropriate site data to Hanes et al. data.

Sulfate. The SRS 1987 seepline concentrations $\left(<1 \times 10^{3} \mu \mathrm{g} / \mathrm{L}\right)$ were much lower than the literature solution value $(1.5 \mathrm{x}$ $10^{5} \mu \mathrm{g} / \mathrm{L}$ ) that proved to be harmful to Nyssa sylvatica. Sulfate is probably not the cause of tree mortality.

Copoer. Lead, and Nickel. The literature concentrations of copper, lead, and nickel that resulted in phytotoxicity are all above the levels that were reported at the SRS F-Area site (Table 7). Therefore, these chemicals are probably not the cause of tree decline. 
Cadminum. The normal cadmium foliage concentration for Nyssa sylvatica is $1 \mu \mathrm{g} / \mathrm{g}$ dry weight. The tissue analysis of the F Area revealed that the foliage concentrations $(0.35$ $\mu \mathrm{g} / \mathrm{g}$ ) were below this level. However, cadmium accumulation occurs primarily in the roots (Jastrow and Koeppe, 1980) and total reliance on the foliar concentrations could lead to erroneous conclusions.

The 1987 seepline cadmium concentration was much higher $(37 \mu \mathrm{g} / \mathrm{L})$ than solution cadmium concentrations that were toxic to Acer saccharum ( $2.5 \mu \mathrm{g} \mathrm{Cd} / \mathrm{L})$ and Acer rubrum $(8.0 \mu \mathrm{g} \mathrm{Cd} / \mathrm{L}$ ) (Table 7). Therefore, there is a potential for cadmium to be toxic.

Zinc. Table 7 shows that the studies by Jordan (1975) on Quercus rubra (Mitchell and Fretz, 1977) are the only ones comparable to the site data. The solutions that were toxic to Quercus rubra ( $1 \times 10^{4} \mu \mathrm{g}$ $\mathrm{Zn} / \mathrm{L}$ and $1 \times 10^{5} \mu \mathrm{g} \mathrm{Zn} / \mathrm{L}$ ) were higher than both the 1987 and 1988 seepline data (1.52 $\mathrm{x}$ $10^{2} \mu \mathrm{g} \mathrm{Zn} / \mathrm{L}$ and $\left.3.0 \times 10^{2} \mu \mathrm{g} \mathrm{Zn} / \mathrm{L}\right)$. However, the solution concentration that was toxic to Acer rubrum ( $25 \mu \mathrm{g} \mathrm{Zn/L}$ ) is much lower than the reported seepline concentrations. Since Acer rubrum is found in the same types of habitats as Nyss sylvatica, Nyssa sylvatica may be as sensitive to zinc as Acer rubrum. Therefore, zinc is another possible candidate for causing tree mortality in the F Area.

\section{F-Area Conclusions}

Based on comparisons between literature and site data, the most likely chemicals responsible for the decline of Nyssa sylvatica are aluminum, manganese, cadmium, and zinc. However, few data are available for Nyssa sylvatica var. biflora. and these conclusions are largely based on findings from other tree species that may have different tolerances. Figures 21 through 25 compare the site values of these chemicals with the literature values that were toxic. Figure 26 compares the normal root manganese concentrations found in the literature with the site data. Of these four chemicals, the site concentrations of aluminum were consistently higher than all reported literature values. The chloride, sodium, and nitrate data were inconclusive and more site data are needed. Sulfate, copper, lead, chromium, and nickel are probably not responsible for mortality. 


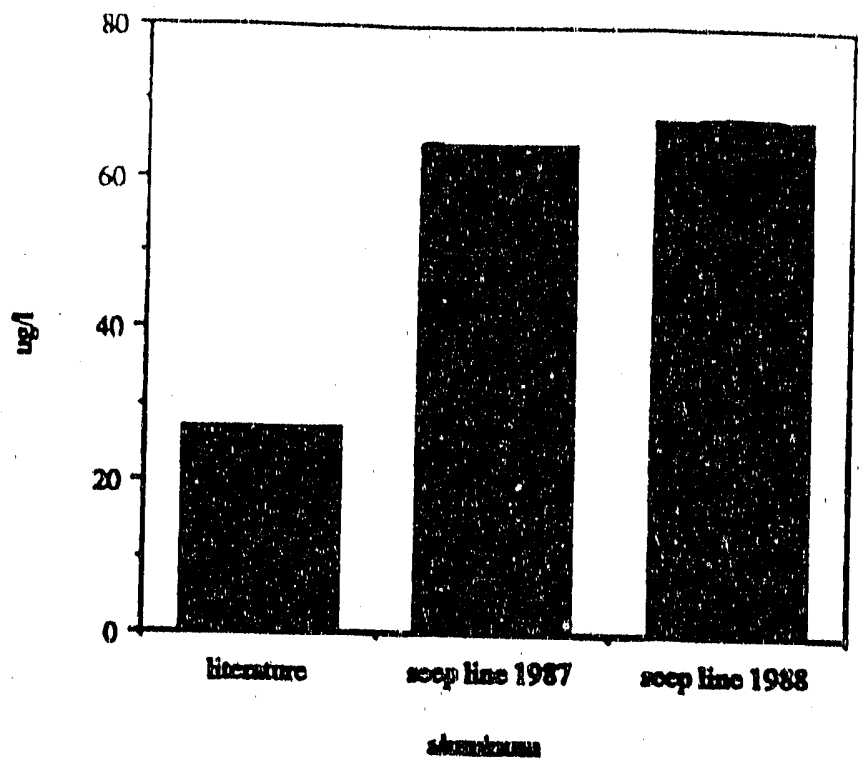

Figure 21. Comparison of aluminum literature solution data with F-Area seepline
data
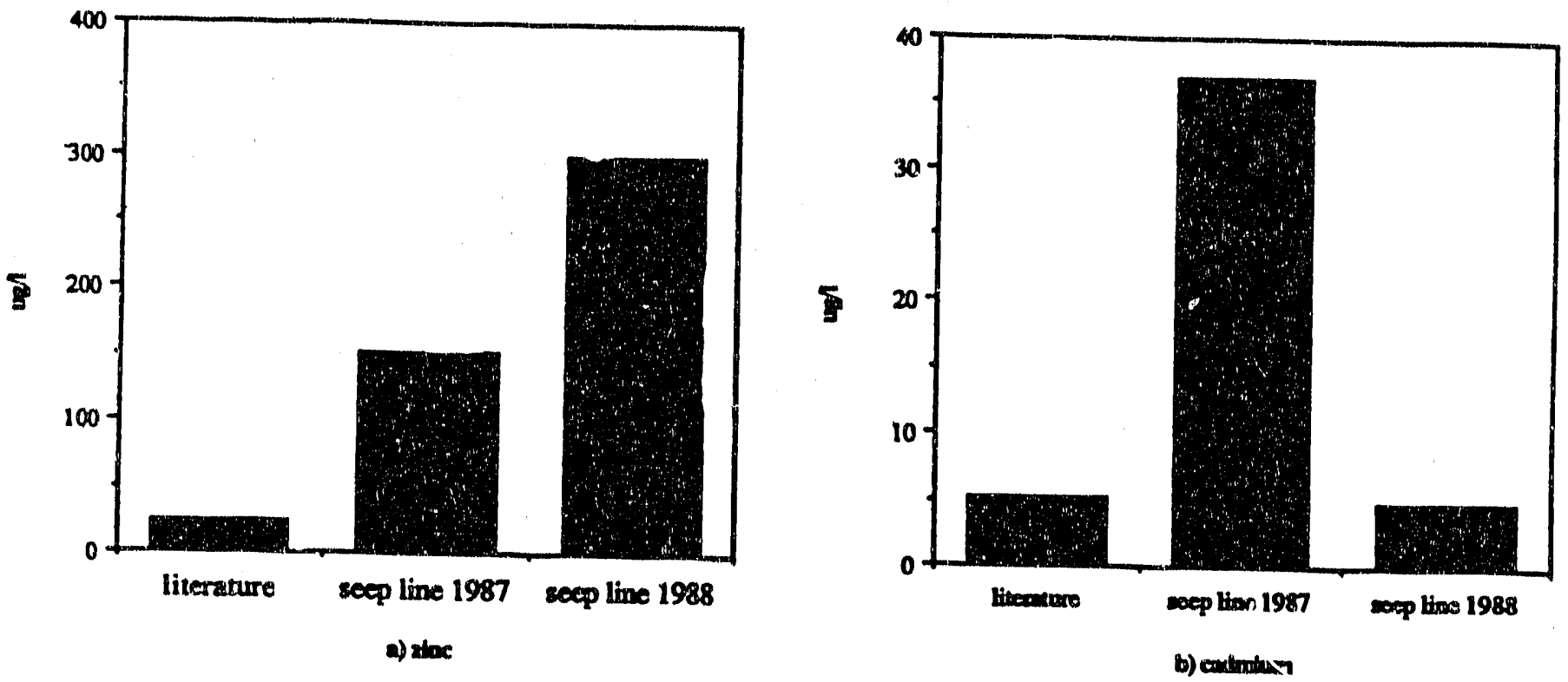

Figure 22. Comparison of zinc and cadmium literature solution data with F-Area
seepline data $-58-$

M9005071 


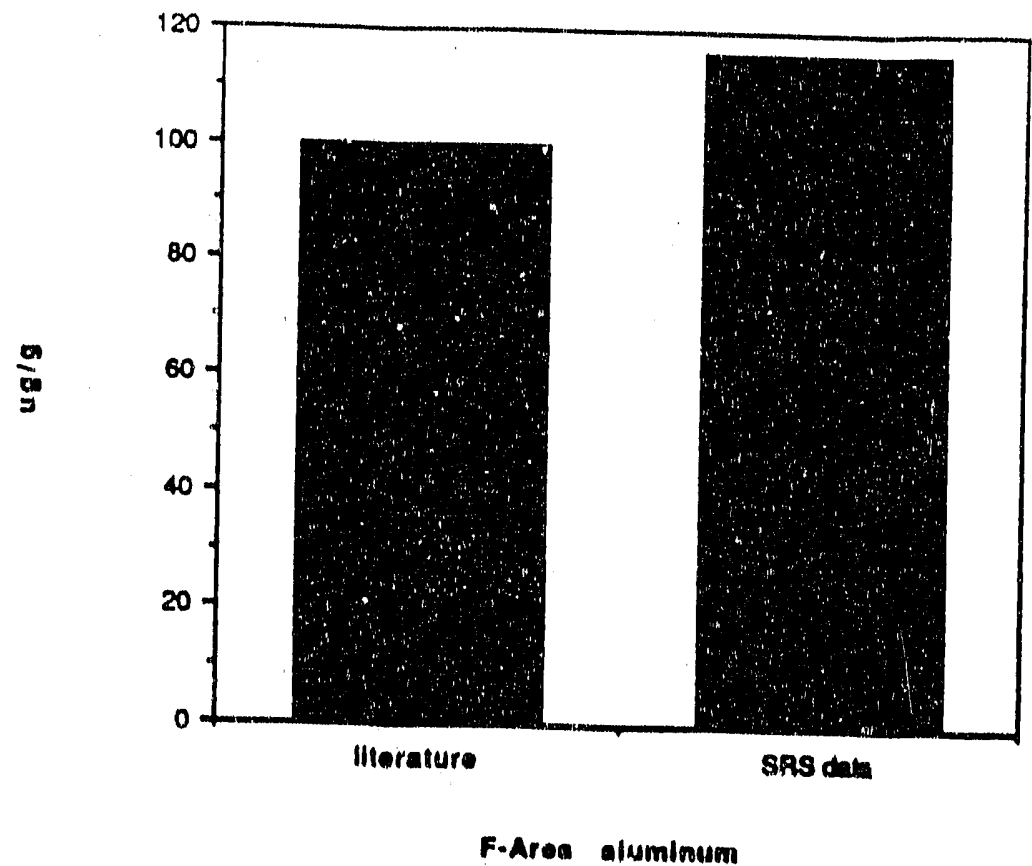

Figure 23. Comparison of aluminum literature leaf data with F-Area leaf data

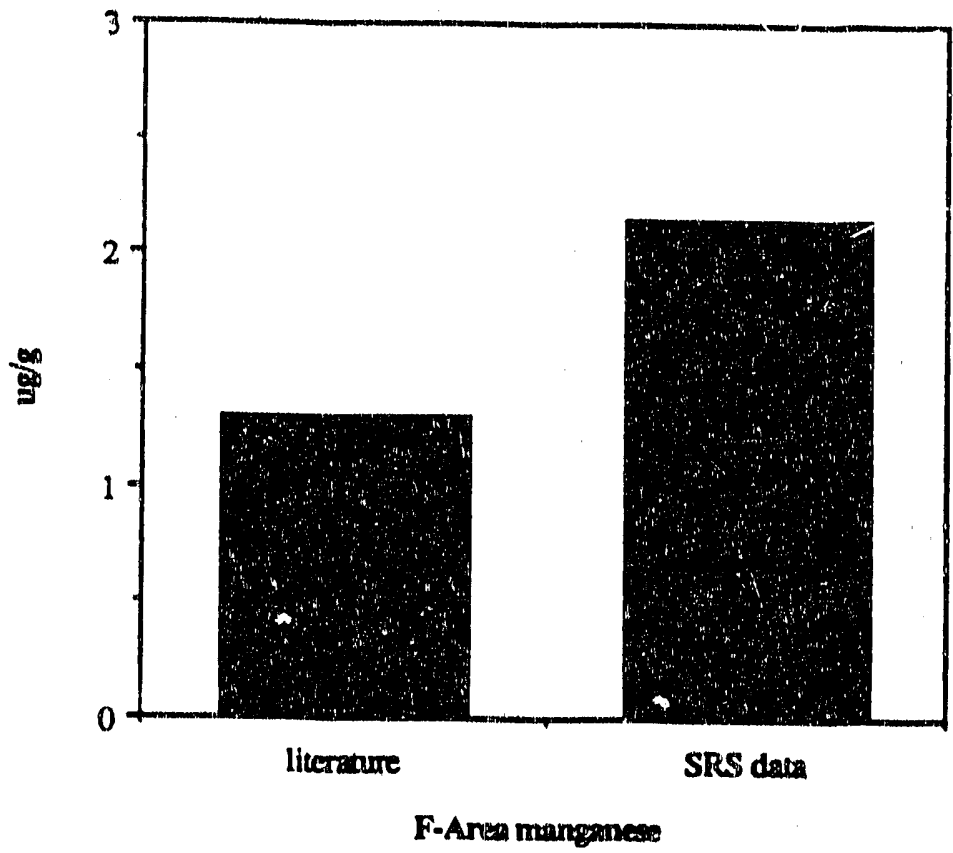

Figure 24. Comparison of manganese literature leaf data with F-Ar a leaf üata -59- 


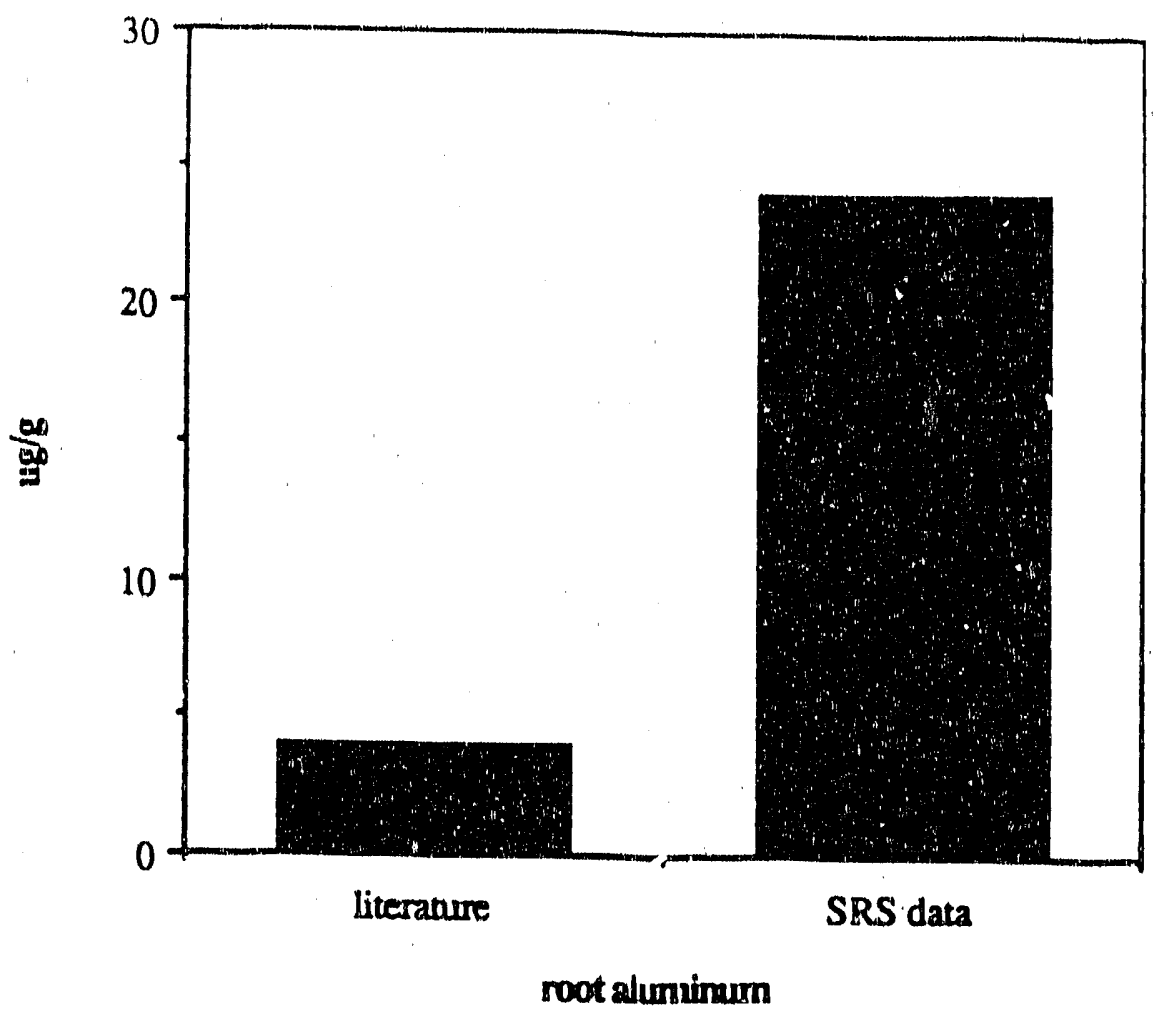

Figure 25. Comparison oi aluminum literature root data with F-Area root data

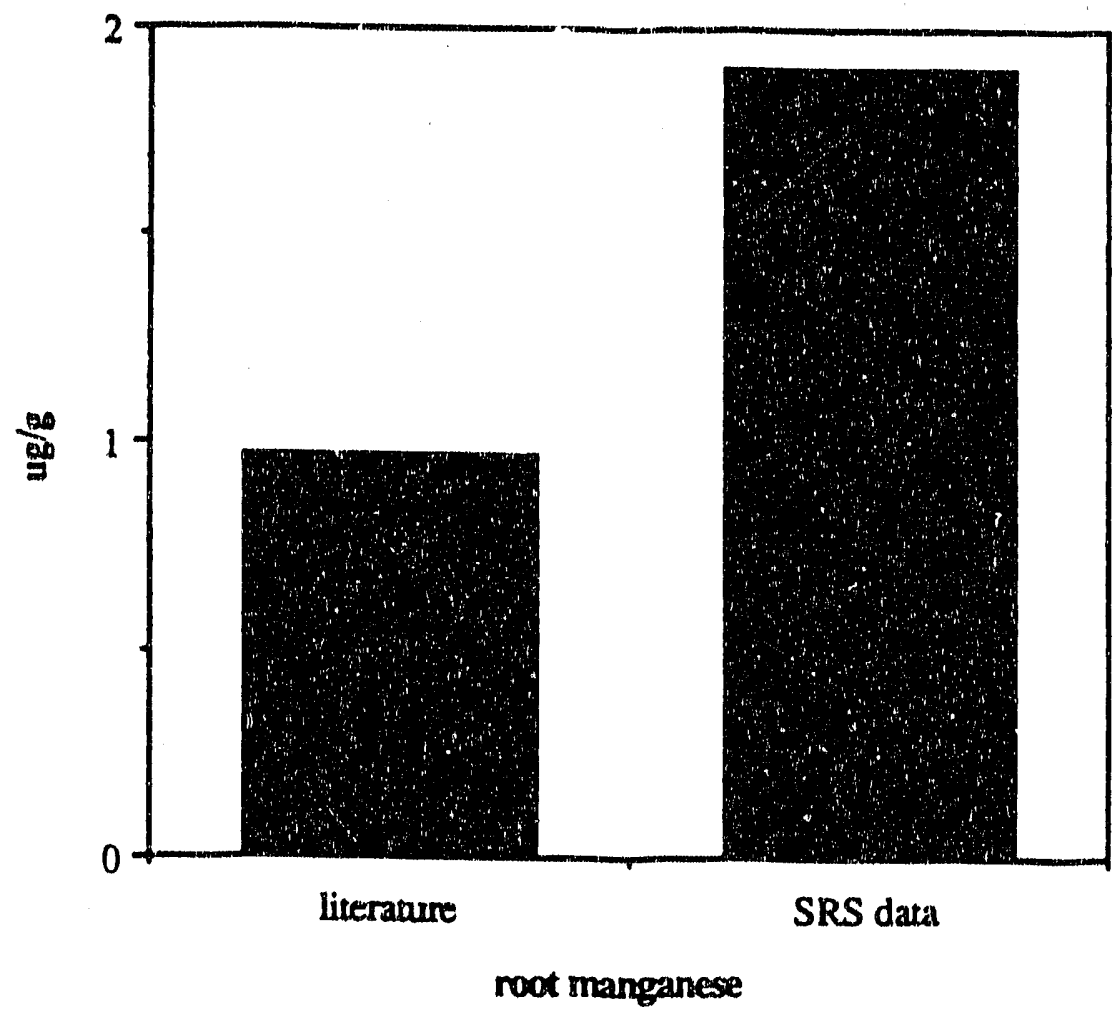

Figure 26. Comparison of Comparison of manganese !iterature root data with FArea root data

$$
.60
$$




\section{H-Area Conclusions}

Comparing literature data with SRS HArea site data (Table 8), gives the same conclusions as F-Area site data for nitrate, sodium, chloride, sulfate, copper, fluoride, lead, and nickel. Only the aluminum, manganese, cadmium, and zinc conclusions differ between the areas.

In the H-Area, the seepline aluminum concentrations $(163 \mu \mathrm{g} / \mathrm{L}$ and $230 \mu \mathrm{g} / \mathrm{L})$ are lower than the literature values (Table 8 ). However, the root $\left(1.43 \times 10^{4} \mu \mathrm{g} \mathrm{Al} / \mathrm{g}\right)$ and foliar $\left(2.08 \times 10^{2} \mu \mathrm{g} \mathrm{Al} / \mathrm{g}\right)$ values are still much higher than the literature values. Figures 27 and 28 compare the tissue concentrations of aluminum with the literature values that were toxic. Aluminum may not be excessive in the H-Area soils, but there is a large quantity of aluminum present in plant tissues. Therefore, aluminum is probably an important factor in the tree decline in the $\mathrm{H}$ Area.

The F-Area manganese tissue concentrations were greatly above the literature values that were toxic (Table 7). In contrast, the $\mathrm{H}$-Area tissue concentrations are well below F-Area values and the literature values (Table 8). Therefore, manganese is probably not a cause of tree mortality in the $\mathrm{H}$-Area. This difference between the F- and $\mathrm{H}$-Area tissue concentrations of manganese may be due to the fact that aluminum levels are much higher in the F-Area (Table 7) than in the $\mathrm{H}$-Area

(Table 8). Higher aluminum concentrations cause 27 increase in the uptake of manganese (Roy c I., 1988).

The F-Area cadmium seepline concentrations were above the literature values that were toxic. In the H-Area, the seepline data and tissue data are much lower than the reported literature values (Table 8 ). Therefore, cadmium is probably not a cause of mortality in the H-Area.

The H-Area seepline zinc concentrations ( $<20 \mu \mathrm{g} \mathrm{Zn} / \mathrm{L}$ ) were much lower than the FArea $\left(1.52 \times 10^{2}\right.$ and $\left.3.0 \times 10^{2} \mu \mathrm{g} \mathrm{Zn} / \mathrm{L}\right)$ and the literature values (Table 8 ). Thus, zinc is probably not an important factor in the $\mathrm{H}$ Area. 


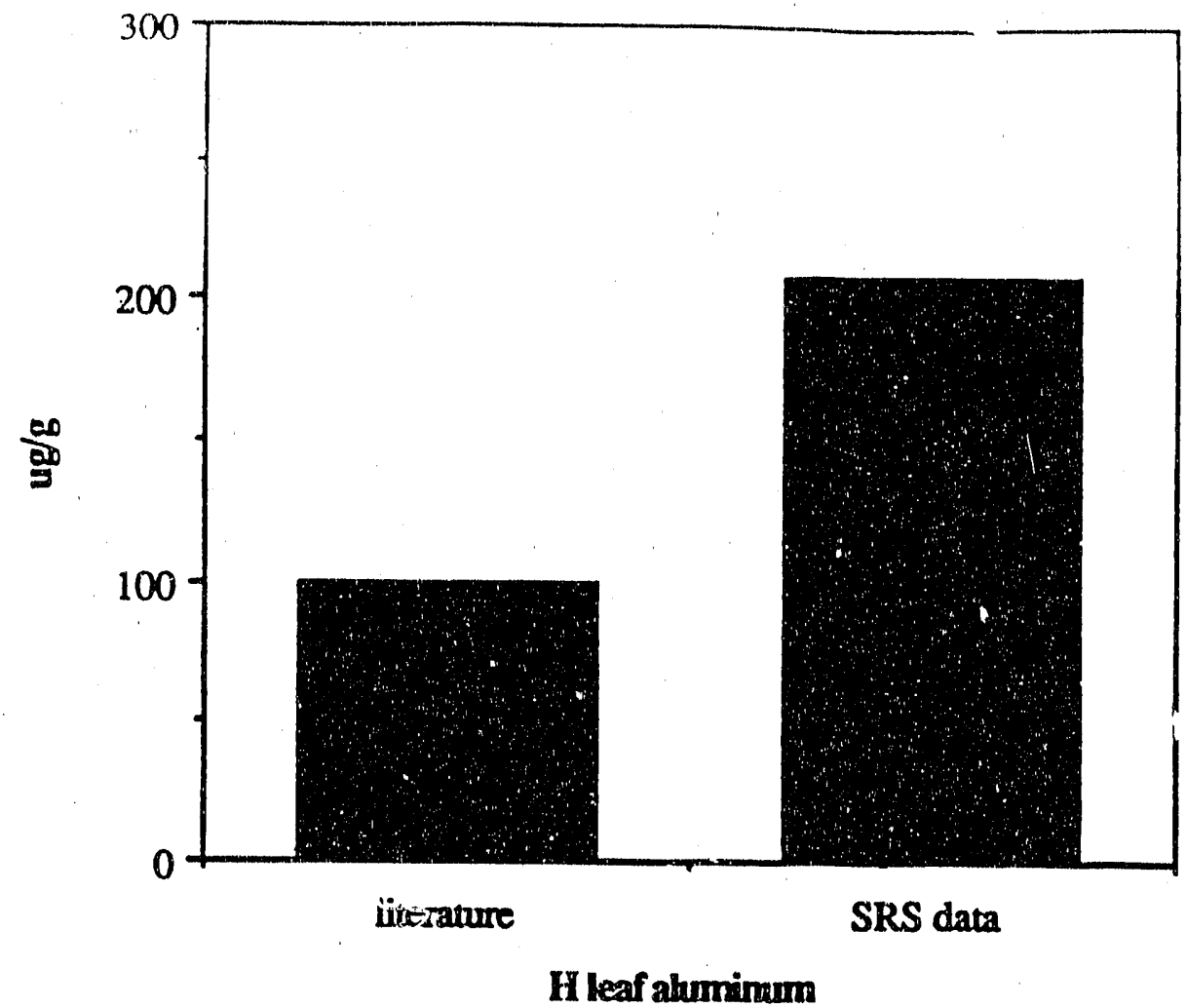

Figure 27. Comparison of aluminum literature leaf data with F-Area leaf data

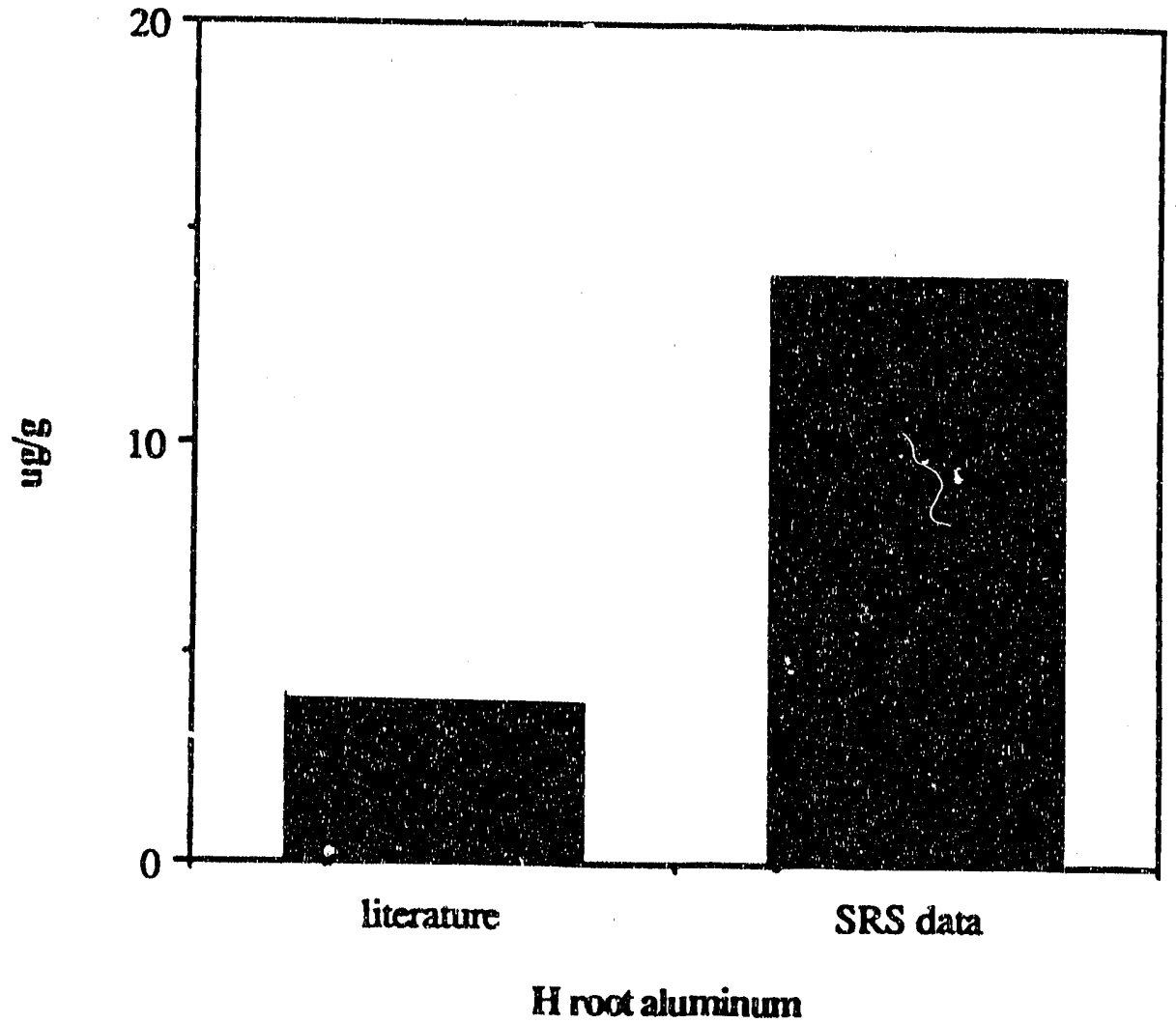

Figure 28. Comparison of aluminum literature root data with H-Area root data -62 - 
Table 8. Comparison of literature data with H-Area data

\begin{tabular}{|c|c|c|c|c|c|c|c|c|c|c|c|c|}
\hline \multirow{3}{*}{ Chemical } & \multirow{3}{*}{$\begin{array}{l}\text { Species } \\
\text { Picsa } \\
\text { nubens }\end{array}$} & \multicolumn{6}{|c|}{ Literaure Data } & \multicolumn{5}{|c|}{ SitL Dati.” } \\
\hline & & \multirow{2}{*}{ Refesences } & \multirow{2}{*}{$\begin{array}{l}\text { Efroct* } \\
(+1-10)\end{array}$} & \multirow{2}{*}{$\begin{array}{l}\begin{array}{c}\text { Conce } \\
\text { Soil } \\
(\mathrm{mg} / \mathrm{g})\end{array} \\
\mathrm{na}\end{array}$} & \multirow{2}{*}{$\begin{array}{c}\begin{array}{c}\text { entration } \\
\text { Solution } \\
(\mathrm{mg} / \mathrm{L})\end{array} \\
5.0 \mathrm{E} 3\end{array}$} & \multicolumn{2}{|c|}{$\begin{array}{c}\text { Tissuc } \\
\text { Roots Leaves } \\
(\mathrm{mg} / \mathrm{g}) \\
\end{array}$} & \multicolumn{2}{|c|}{$\begin{array}{c}\text { Seepline } \\
\text { (mg/L) } \\
19871 \quad 1988^{\circ}\end{array}$} & \multirow{2}{*}{$\begin{array}{l}\begin{array}{l}\text { Soil } \\
\text { Data } \\
(\mathrm{mg} / \mathrm{g})\end{array} \\
412\end{array}$} & \multicolumn{2}{|c|}{$\begin{array}{l}\text { Tissuc Dalta } \\
\text { Roots Learcs } \\
(\mathrm{mg} / \mathrm{g})\end{array}$} \\
\hline & & & & & & na & na & 163 & 230 & & $1-339$ & 208 \\
\hline & $\begin{array}{l}\text { Picea } \\
\text { glauca }\end{array}$ & A & $\cdot$ & na & $5.0 \mathrm{E} 3$ & na & na & & & & & \\
\hline & $\begin{array}{l}\text { Picea } \\
\text { coariana }\end{array}$ & A & $\cdot$ & na & $2.0 \mathrm{EA}$ & na & na & & & & & \\
\hline & Pimus & A & - & na & $4.0 \mathrm{E} 4$ & na & na & & & & & \\
\hline & $\begin{array}{l}\text { Pinus } \\
\text { strobus }\end{array}$ & $A$ & - & na & $4.0 \mathrm{EA}$ & na & na & & & & & \\
\hline & $\begin{array}{l}\text { Acer } \\
\text { sacchanum }\end{array}$ & $\mathrm{Tl}$ & + & na & $2.7 \mathrm{E}_{3}$ & $2.0 \mathrm{E} 3$ & 75 & & & & & \\
\hline & $\begin{array}{l}\text { Acer } \\
\text { saccharem }\end{array}$ & $\mathrm{TI}$ & + & na & $1.35 \mathrm{E} 4$ & na & na & & & & & \\
\hline & $\frac{\Delta a c r}{\text { sacctanum }}$ & $\mathrm{TI}$ & $"$ & na & $>2.7 \mathrm{E} 4$ & $4.0 \mathrm{E} 3$ & 100 & & & & & \\
\hline & $\begin{array}{l}\text { Picas } \\
\text { nubens }\end{array}$ & $T 2$ & - & na & $26.7 \mathrm{E3}$ & $\begin{array}{l}6.0 \mathrm{E3}- \\
1.34 \mathrm{E} 4^{d}\end{array}$ & $70-170^{d}$ & & & & & \\
\hline Nitrate & Piceanabies & $G$ & + & na & $6.2 \mathrm{EA}$ & ma & na & $2.85 \mathrm{E} 4$ & $1.3 \mathrm{EA}$ & nd & nd & nd \\
\hline \multirow[t]{3}{*}{$\mathrm{Mn}$} & ng & B & - & na & 1E3-1ES & na & & 145 & 35 & 14 & 490 & 566 \\
\hline & $\frac{\text { Nyssa }}{\text { sylvatia }}$ & $\mathbf{K}$ & 0 & na & na & 965 & na & & & & & \\
\hline & $\begin{array}{l}\text { Becula } \\
\text { alleghancin } \\
\text { sis }\end{array}$ & 110 & - & $\mathbf{m a}$ & $2.5 E 4$ & ma & $\begin{array}{l}1.3 \mathrm{E} 3 . \\
\text { IES }\end{array}$ & & & & & \\
\hline \multirow[t]{2}{*}{$\mathrm{Na}$} & $\begin{array}{l}\text { Thuia } \\
\text { eccidentalis }\end{array}$ & $F M$ & - & $4.8 \mathrm{E} 2$ & $3.45 \mathrm{E} 7$ & ma & $3.0 \mathrm{E} 3$ & $6.84 \mathrm{E} 4$ & $7.8 \mathrm{EA}$ & 123.3 & $1.34 \mathrm{E} 3$ & 388 \\
\hline & $\begin{array}{l}\text { Liniodendron } \\
\text { bulioifere }\end{array}$ & H & 0 & $\begin{array}{l}1.86 \mathrm{E}- \\
1.53 \mathrm{E} 3\end{array}$ & ma & na & $\begin{array}{l}\text { 1.SE2- } \\
4.0 \mathrm{E} 2\end{array}$ & & & & & \\
\hline \multirow[t]{2}{*}{$\mathrm{Cl}$} & $\begin{array}{l}\text { Thuia } \\
\text { occidensalis }\end{array}$ & FM & - & $5.6 \mathrm{E2}$ & S.32E7 & ma & $1.64 \mathrm{EA}$ & $5.3 \mathrm{E} 3$ & $4.0 \mathrm{E} 3$ & $n^{n}$ & nd & nd \\
\hline & $\begin{array}{l}\text { Lirodendron } \\
\text { rulipifera }\end{array}$ & $H$ & - & $8.42 \mathrm{E} 2$ & na & na & $6.14 E_{3}$ & & & & & \\
\hline
\end{tabular}


Table 8. Comparison of literature data with H-Area data (Contd)

\begin{tabular}{|c|c|c|c|c|c|c|c|c|c|c|c|c|}
\hline \multirow{3}{*}{ Ohernical } & \multirow{3}{*}{$\frac{\text { Species }}{\text { Lulipifer }}$} & \multirow{3}{*}{$\frac{\text { References }}{\mathrm{H}}$} & \multicolumn{3}{|c|}{ Litcrature Dalli } & \multicolumn{7}{|c|}{ Sile Datla $=$} \\
\hline & & & \multirow{2}{*}{$\frac{\begin{array}{l}\text { Effect* } \\
(+1-N)\end{array}}{-d}$} & \multirow{2}{*}{$\begin{array}{l}\begin{array}{c}\text { Conce } \\
\text { Soil } \\
(\mathrm{mg} / \mathrm{g})\end{array} \\
2.0 \mathrm{E} 3\end{array}$} & \multirow{2}{*}{$\frac{\begin{array}{c}\text { entration } \\
\text { Solution } \\
(\mathrm{mg} / \mathrm{L})\end{array}}{\mathrm{na}}$} & \multicolumn{2}{|c|}{$\begin{array}{c}\text { Tissue } \\
\text { Roots Leaves } \\
\text { (mg/g) }\end{array}$} & \multicolumn{2}{|c|}{$\begin{array}{c}\text { Secpline } \\
\text { (m\&/L) } \\
19871 \text { 19881 }\end{array}$} & \multirow[t]{2}{*}{$\begin{array}{l}\text { Soil } \\
\text { Data } \\
(\mathrm{mg} / \mathrm{g})\end{array}$} & \multicolumn{2}{|c|}{$\begin{array}{c}\text { Tissuc Dila } \\
\text { Roots Leaves } \\
\text { (mg/g) }\end{array}$} \\
\hline & & & & & & na & na & & & & & \\
\hline Sulfate & $\begin{array}{l}\text { Nyssa } \\
\text { sylvacica }\end{array}$ & RI & - & na & $1.5 \mathrm{ES}$ & na & na & 1.540 & nd & nd & nd & nd \\
\hline \multirow[t]{2}{*}{$\mathrm{Cu}$} & $\begin{array}{l}\text { Acer } \\
\text { nubrom }\end{array}$ & $S T$ & 0 & na & sa & 10 & $4.0-12.7$ & $<50$ & $<I D L$ & $\angle I D L$ & nd & nd \\
\hline & $\begin{array}{l}\text { Acer } \\
\text { nubrum }\end{array}$ & HO & - & na & $4.0 \mathrm{E} 3$ & $1.39 \mathrm{E}$ & 3 ma & & & & & \\
\hline \multirow[t]{2}{*}{$\mathrm{Pb}$} & ng & DB & 0 & $20-200$ & $<3.0 \mathrm{E3}$ & na & ma & 3.0 & $<5$ & nd & nd & nd \\
\hline & $\begin{array}{l}\text { Acer } \\
\text { nebrum }\end{array}$ & DB & - & $\mathbf{m} \mathbf{2}$ & $2.07 \mathrm{ES}$ & na & na & & & & & \\
\hline \multirow[t]{3}{*}{$\mathrm{Ni}$} & $\mathrm{ng}$ & $\mathbf{B}$ & 0 & na & $\begin{array}{l}5.0 \mathrm{E} 2- \\
2.0 \mathrm{E} 3\end{array}$ & na & na & 50 & $<I D L$ & $\angle I D L$ & nd & nd \\
\hline & $\begin{array}{l}\text { Acar } \\
\text { nubrom }\end{array}$ & DB & 0 & na & $1.0 \mathrm{E} 4$ & na & na & & & & & \\
\hline & $\begin{array}{l}\text { Lonicera } \\
\text { Latarica }\end{array}$ & DB & $\cdot$ & na & $1.0 \mathrm{EA}$ & na & ma & & & & & \\
\hline
\end{tabular}


Table 8. Comparison of literature data with H-Area data (Contd)

\begin{tabular}{|c|c|c|c|c|c|c|c|c|c|c|c|c|}
\hline \multirow{3}{*}{$\frac{\text { Chemical }}{\text { Cd }}$} & \multirow{3}{*}{$\frac{\text { Species }}{\text { Nyssa sylvatica }}$} & \multirow{3}{*}{$\frac{\text { References }}{\mathrm{BU}}$} & \multicolumn{3}{|c|}{ Litcrature Data } & & & \multicolumn{5}{|c|}{$\sin$ Das $\cdots$} \\
\hline & & & \multirow{3}{*}{$\begin{array}{l}\begin{array}{l}\text { Efrect* } \\
(+1-N)\end{array} \\
0 \\
0\end{array}$} & \multirow{3}{*}{$\begin{array}{l}\begin{array}{c}\text { Conce } \\
\text { Soil } \\
(\mathrm{mg} / \mathrm{g})\end{array} \\
9.0 \mathrm{E} 2 . \\
1.5 \mathrm{E} 3 \\
2.0-3.0\end{array}$} & \multirow{3}{*}{$\begin{array}{l}\begin{array}{c}\text { entration } \\
\text { Solution } \\
(\mathrm{mg} / \mathrm{L})\end{array} \\
\text { na } \\
\text { na }\end{array}$} & \multicolumn{2}{|c|}{$\begin{array}{c}\text { Tissuc } \\
\text { Roots Leaves } \\
(\mathrm{mg} / \mathrm{g}) \\
\end{array}$} & \multicolumn{2}{|c|}{$\begin{array}{c}\begin{array}{c}\text { Secplune } \\
(\mathrm{mg} / \mathrm{L})\end{array} \\
19871 \quad 19881 \\
\end{array}$} & \multirow{2}{*}{$\begin{array}{l}\begin{array}{l}\text { Soil } \\
\text { Dilla } \\
(\mathrm{mg} / \mathrm{g})\end{array} \\
\text { nd }\end{array}$} & \multicolumn{2}{|c|}{$\begin{array}{l}\text { Tissuc Didul } \\
\text { Roots Lcive } \\
\text { (ng/g) }\end{array}$} \\
\hline & & & & & & na & 70 & $<0.1$ & $<5$ & & 0.08 & 0.15 \\
\hline & Nesylyatica & BU & & & & na & 1 & & & & & \\
\hline & Quencus ruba & $\mathrm{BU}$ & 0 & $2.0-3.0$ & nat & ma & na & & & & & \\
\hline & Q Qubra & BU &.$d$ & $10-500$ & na & ra & 47 & & & & & \\
\hline & $\begin{array}{l}\text { Acex } \\
\text { saccharimum }\end{array}$ & LC & $\cdot$ & na & 2.5 & na & na & & & & & \\
\hline & A. nubnum & MF & - & na & 8.0 & 446.9 & 22.8 & & & & & \\
\hline \multirow[t]{7}{*}{$\mathrm{Zn}$} & $\frac{\text { Nyssa }}{\text { syluatica }}$ & VH, BU & 0 & $\begin{array}{l}2.0 \mathrm{EE} 3- \\
2.0 \mathrm{E} 4\end{array}$ & na & na & 40 & $<20$ & $<20$ & nd & nd & nd \\
\hline & Nosylvatica & $\mathrm{BU}$ & - & $5.0 \mathrm{E} 4$ & $\mathrm{ma}$ & na & $3.0 \mathrm{E} 3$ & & & & & \\
\hline & Quercus ruba & BU & 0 & $\begin{array}{l}1.0 \mathrm{E} 2- \\
3.0 \mathrm{E} 2\end{array}$ & na & na & na & & & & & \\
\hline & Q.nubra & $\mathrm{BU}$ & $d$ & $\begin{array}{l}2.0 \mathrm{E} 3- \\
2.0 \mathrm{E} A\end{array}$ & na & na & $\begin{array}{l}4.0 \mathrm{E} 2- \\
5.0 \mathrm{E} 2\end{array}$ & & & & & \\
\hline & Q. nibra & 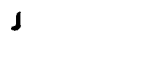 & - & ma & $1.0 \mathrm{EA}$ & na & $\begin{array}{l}2.37 \mathrm{E2}- \\
3.7 \mathrm{AE2}\end{array}$ & & & & & \\
\hline & Q. nubra & J & $d$ & ma & 1.0ES & na & na & & & & & \\
\hline & Ales ruboum & MF & - & ma & 25 & $1.43 \mathrm{E}$ & 3 4.21EZ & & & & & \\
\hline
\end{tabular}


Table 8. Comparison of literature data with H-Area data (Contd)

nd nor delociod

ng data nor given

na daca nox applicable

- Erfects are ranked according $\omega$ their effoct on growht + means a positive growth effect occurred: - means a negative grow'h effect occurned: 0 - no growth effoct occurred. For further details, consult the appropriale section in the literature revicw.

** All sive tissue data are reporked for $\mathrm{N}$ sylvatica from the most severely stressed siles in the F Area. The soils and tissues were unalyzed at Duke University. For those not analyzed at Duke, MetaTRACE and TMA values are used. Aluminum values are Oxalate extraction data.

a indicales a $+1-0$ effect on photosynthesis rates

indicales $a+1-10$ effect on respiration rates

indicates a $+1-10$ effect on soedling death

1987 scepline dain from Looney a al. (1988)

1988 seepline datu from Thermo Arulytical, Inc. (TMA)

A Andersson (1988)

TI Thomton el al. (1986)

i2 Thomton ex al. (1987)

SS Shortle and Smith (1988)

K Ketey (1979)

FM Foster and Mam (1978)

RI Richardson el al. (1988)

ST Slone and Tunmer (1975)

HO Hoake and Ormmod (1972)

BW Braen and Weinstein (1985)

B Bowen (1979)

DB Davis and Bames (1975)

H Hanes ex al (1976)

$\mathrm{HB}$ Holmes and Baker (1966)

$G$ Godbold a al. (1988)

BU Buchauler (1973)

LC Lamoreaux and Chancy (1977)

MF Michicll and Fretz (1977)

VH Van Hook et al. (1980)

J Jordan (1975)

HO Hoyle (1972) 
In the H-Area, the most likely chemical responsible for tree decline is aluminum. Manganese, cadmium, zinc, nitrate, sulfate, copper, fluoride, lead, and nickel are probably not responsible. Sodium could have been higher in the period of tree death and thus needs to be considered as a possible toxic agent.

\section{CONCLUSIONS}

This study found that the most likely causes of tree decline in the F-Area are: aluminum, manganese, cadmium, and zinc. In the H-Area, the most likely cause is aluminum. However, since the trees died over a decade ago, there is no guarantee that these are the only factors contributing to mortality.

\section{FINAL CONCLUSIONS}

It was originally hypothesized that the most likely hydrological stressors to Nyssa sylvatica var. biflora were flooding where water levels cover the lenticels for more than 26 percent of the growing season, which results in low oxygen availability, and toxins occuring in anaerobic environments. Because of inputs of water from the seepage basins, flooding could have occurred, but no evidence for flooding could be found. In fact, trees began to show stress following two drought years (1977-1978) rather than a wet year, and died during a second drought year (1980). Dry conditions could exacerbate stress by concentrating contaminants.

Study of the soil and water chemical parameters in the impacted sites indicated that salt concentrations in the affected areas have produced abnormally high exchangeable sodium percentages. Furthermore, significantly elevated concentrations of heavy metals were found in each impacted site, although no one metal was consistently elevated. This condition may have led to direct toxicity by a different factor in each area or the heavy metals may have acted as an intermediary for other agents, such as manganese toxicity.

Evaluation of the concentrations of various chemicals toxic to Nyssa sylvatica var. biflora revealed that aluminum was probably the most toxic in F-Area. Manganese, cadmium, and zinc had concentrations great enough to be considered possible causes of tree mortality in the FArea. Aluminum was the most likely cause of mortality in the H-Area. Sodium was very high in both areas but plant responses to sodium are highly variable, so it is difficult to evaluate the role of sodium given the available information. 


\section{LITERATURE CITED}

Andersson, M., 1988, "Toxicity and Tolerance of Aluminum in Vascular Plants". Water, Air, and Soil Pollution, pp 439-462.

Applequist, M.B., 1959, A Study of Soil and Site Factors Affecting the Growth and Development of Swamp Blackgum and Tupelo Gum Stands in Southeastern Georgia. Master's Thesis, Duke University, Durham, NC.

Bartlett, R.J. and J.M. Kimble, 1976a, "Behavior of Chromium in Soils: I. Trivalent Forms". J. Env. Qual., 5:379-383.

Bartlett, R.J. and J.M. Kimble, 1976b, "Behavior of Chromium in Soils: II. Hexavalent Forms". J. Env. Qual., 5:383-386.

Bohn, H.L., B.L. McNeal, and G.A. O'Conner, 1985, Soil Chemistry. Wiley-Interscience, New York.

Bowden, W.B., 1987, "The Biogeochemistry of Nitrogen in Freshwater Wetlands". Biogeochemistry, 4:313-348.

Bowen, 1979, Environmental Chemistry of the Elements. Academic Press, London, 333 pp.

Braen, S.N. and L.H. Weinstein, 1985, "Uptake of Fluoride and Aluminum by Plants Grown in Contaminated Soils". Water, Air, and Soil Pollution, 24:215-223.

Briscoe, C.B, 1957, Diameter Growth and Effects of Flooding on Certain Bottomlana Forest Trees. Ph.D Dissertation, Duke University, Durham, NC.

Buchauer, M.J., 1973, "Contamination of Soil and Vegetation Near a Zinc Smelter by Zinc, Cadmium, Copper, and Lead". Environmental Science and Technology, 7(2):131-135.

Callahan, M.A., M.W. Slimak, N.W. Gabel, I.P. May, and others, 1979, "Water Related Fate of 129 Priority Pollutants, Vol.1". United States Environmental Protection Agency, EPA440/4-79-029a.

Coleman, R.N., 1988, "Chromium Toxicity: Effects on Microorganisms with Special Reference to the Soil Matrix". in J.O. Nriagu and E. Nieboer (eds). Chromium in the Natural and Human Environments, Wiley, New York.

Collins, J.F. and S.W. Buol, 1970, "Effects of Fluctuations in the Eh-pH Environments on Iron and/or Manganese Equilibrium". Soil Sci. 110:111-118.

Coughtrey, P.J. and M.C. Thorne, 1983, Radionuclide Distribution and Transport in Terrestrial and Aquatic Ecosystems, a Critical Review of the Data. Vol. 2, A.A. Balkema, Rotterdam.

Christensen, E.J. and D.E. Gordon, 1983, Technical Summary of Groundwater Protection Program at the Savannah River Plant, Vol. I: Site Geohydrology and Solid and Hazardous Wastes. E. I. du Pont de Nemours and Co., Savannah River Laboratory, Aiken, SC, DPST-83-829. 
Davies, B.E., 1987, "Plant Avallability of Heavy Metals in Solls". in Pollutant Transport and Fate in Ecosystems. P.J. Coughtrey, M.H. Martin, and M.H. Unsworth (eds.), The British Ecological Society, London, pp 267-275.

Davis, J.B. and R.L. Bames, 1973, "Effects of Soil Applied Fluoride and Lead on Growth of Loblolly Pine and Maple". Environmental Pollution, 5:35-44.

Dickson, R.E. and T.C. Broyer, 1972, "Effects of Aeration, Water Supply, and Nitrogen Source on Growth and Development of Tupelo Gum and Bald Cypress". Ecology, 53:626-634.

Donner, H.E., S.J. Traina and A. Pukite, 1982, "Interactions of Nickel, Copper and Cadmium with Soil Manganese in Saline Solution". Soil Sci., 13:396-377.

Dragun, J., 1988, The Soil Chemistry of Hazardous Matci ials. Hazardous Materials Control Research Institute, Silver Spring, Maryland.

Engler, R.M. and W.H. Patrick, 1975, "Stability of Sulfides of Manganese, Iron, Zinc, Copper and Mercury in Flooded and Nonflooded Soil". Soil Sci., 119:217-221.

EPA, 1986, "Quality Criteria for Water". United States Environmental Protection Agency. EPA440/5-86-001.

Epstein, E., 1972, Mineral Nutrition of Planis: Principles and Perspectives. John Wiley and Sons, Inc., New York, 412 pp.

Exploration Resources, 1989, The Savannah River Site's Groundwater Monitoring Program Conducted by the Environmental and Health Protection Department.

Foster, A.C. and M.A. Maun, 1978, "Effects of Highway Deicing Agents on Thuja occidentalis in a Greenhouse". Canadian Journal of Botany, 56:2760-2766.

Fuller, W.H., N.E. Korte, E.E. Nieble, and B.A. Alesii, 1976, "Contribution of the Soil to the Migration of Certain Common and Trace Elements". Soil Sci., 122:223-235.

Gambrell, R.P and W.H. Patrick, 1978, "Chernical and Microbiological Properties of Anaerobic Soils and Sediments" in D.D. Hook and R.M.M. Crawford (eds). Plant Life in Anaerobic Environments, Ann Arbor Sci. Pub. Inc., Ann Arbor, MI, pps 375-423.

Gill, C.J., 1970, "The Flooding Tolerance of Woody Species- A Review". For. Abstr., 31(4):671-688.

Godbold, D.L., K. Dictus, and A. Huttermann, 1988, "Influence of Aluminum and Nitrate on Root Growth and Mineral Nutrition of Norway Spruce Seedlings". Canadian Journal of Forest Research, Vol. 18:1167-1171.

Gotoh, S. and W.H. Patrick, 1972, "Transformation of Manganese in a Waterlogged Soil as Affected by Redox Potential and pH". Soil Sci. Soc. Amer. Proc. J, 36:738-742.

Hahne, H.C.H. and W. Kroontje, 1973, "Significance of pH and Chloride Concentration on Behavior of Heavy Metal Pollutants: Mercury(II), Cadmium(II), Zinc(II), and Lead(II)". $J$. Env. Qual., 2:444-450.

Hall, T.F. and G.E. Smith, 1955, Effects of Flooding on Woody Plants, West Sandy Dewatering Project, Kentucky Reservoir". J. Forestry, Vol. 53. 
Hall, T.F. and G.E. Smith, 1955, Effects of Flooding on Woody Plants, West Sandy Dewatering Project, Kentucky Reservoir". J. Forestry, Vol. 53.

Hanes, R.E., L.W. Zelazny, K.G. Verghese, R.P. Bosshart, E.W. Carson Jr., R.E. Blaser, and D.D. Wolf, 1976, "Effects of Deicing Salts on Plant Biota and Soil". National Cooperative Highway Research Program Report 170, Transportation Research Board, Washington, D.C.

Harms, W.R., H.T. Schreuder, D.D. Hook, C.L. Brown, and F.W. Shropshire, 1980, "The Effects of Flooding on the Swamp Forest in Lake Ocklawaha, Florida". Ecology, 61(6):1412-1421.

Haselow, J. M.Harris, B.B. Looney, N.V. Halverson, and J.B. Gladden, 1990, Analysis of Soil and Water at the Four Mile Creek Seepline near the F\&H Areas of SRS. WSRC-RP-90591. WSRC Savannah River Lab, Aiken, SC.

Hawkins, R.H., 1971, Mineralogy and Ion Exchange Characteristics of Savannah River Plant Stream Bed Sediments. E.I. du Pont de Nemours and Company, Savannah River Laboratory, Aiken SC, DPST-71-332.

Heale, E.L. and D.P. Ormrod, 1981, "Effects of Nickel and Copper on Acer rubrum, Cornus stolonifera, Lonicera tatarica, and Pinus resinosa". Canadian Journal of Botany, 60:26742681.

Hook, D.D., 1968, Growth and Development of Swamp Tupelo under Different Root Environments. Ph.D. Dissertation, University of Georgia, Aisens, GA.

Hook, D.D. 1984, "Waterlogging Tolerance of Lowland Tree Species of the South". SJAF, 8(3):217-224.

Hook, D.D. and C.L. Brown, 1972, "Permeability of the Cambium to Air in Trees Adapted to Wet Habitats". Bot Gaz, 133(3):304-310.

Hook, D.D. and C.L. Brown, 1973, "Root Adaptations and Relative Flood Tolerance of Five Hardwood Species". For Sci,19(3):225- 229.

Hook, D.D., C.L. Brown, and P.P. Kormanic, 1970, "Lenticel and Water Root Development of Swamp Tupelo Under Various Flooding Conditions". Bot Gaz, 131(3):217-224.

Hook, D.D., C.L. Brown, and P.P. Kormanic, 1971, "Inductive Flood Tolerance in Swamp Tupelo". J Exp Bot, 22:78-89.

Hook, D.D., C.L. Brown, and R.H. Wetmore, 1972, "Aeration in Trees". Bot Gaz, 133(4):443454.

Hook, D.D., D.S. Debell, W.H. Mckee, Jr., and J.L. Askew, 1983, "Responses of Loblolly Pine (Mesophyte) and Swamp Tupelo (Hydrophyte) Seedlings to Soil Flooding and Phosphorus". Plant and Soil, 71:387-394.

Hook, D.D. and Scholtens, eds. 1978, "Adaptations and Flood Tolerance of Tree Species". in Plant Life in Anaerobic Environments. Ann Arbor Sci Publ, Inc., Ann Arbor, MI.

Hoyle, M.C., 1972, "Manganese Toxicity in Yellow Birch (Betula alleghaniensis Britton) Seedlings". Plant and Soil, 36:229-232. 
Jastrow, J.D. and D.E. Koeppe, 1980, "Uptake and Effects of Cadmium in Higher Plants". in Cadmium in the Enviromment -Part I: Ecological Cycling. J.O. Nriagu ed., John Wiley and
Sons, New York, pp 607-638.

Jordan, M.J., 1975, "Effects of a Zinc Smelter Emissions and Fire on a Chestnut-oak Woodland". Ecology, 56:78-91.

Keeley, J.E., 1978, "Malic Acid Accumulation in Roots in Response to Flooding: Evidence Contrary to its Role as an Altemative to Ethanol". J Exp Bot, 29(113):1345-1349.

Keeley, J.E., 1979, "Population Differentiation Along a Flood Frequency Gradient: Physiological Adaptations to Flooding in Nyssa sylvatica". Ecol Monog: 89-108.

Keeley, J.E. and E.H. Franz, 1979, Alcoholic Fermentation in Swamp and Upland Populations of Nyssa sylvatica: Temporal Changes in Adaptive Strategy". Amer Nat, 133(4):587-592.

Keren, R. and I. Shainberg, 1984, "Colloid Properties of Clay Minerals in Saline and Sodic Solution". in I. Shainberg and J. Shalvevet (eds), Ecological Studies 51: Soil Salinity Under Irrigation: Process and Maragement, Springer Verlag, Heidelberg.

Khattak, R.A., W.M. Jarrell, and A.L. Page, 1989, "Mechanism of Native Manganese Release in Salt-Treated Soils" Soil Sci. Soc. Am. J., 53:701-705.

Killian, T.H., N.L. Colb, P. Corbo, and I.W. Marine, 1987a, Environmental Information Document F-Area Seepage Basin. DPST-87-704. E.I. du Pont de Nemours and Company, Savannah River Laboratory, Aiken, SC.

Killian, T.H., N.L. Colb, P. Corbo, and I.W. Marine, 1987b, Environmental Information Document H-Area Seepage Basin. , DPST-87-706. E.I. du Pont de Nemours and Company, Savannah River Laboratory, Aiken, SC.

Korte, N.E., J. Skopp, E.E. Niebla, and W.H. Fuller, 1975, "A Baseline Study on Trace Metal Elution From Diverse Soil Types". Water Air and Soil Pollution, 5:149-156.

Korte, N.E., J. Skopp, W.H. Fuller, E.E. Niebla, and B.A. Alesii, 1976, "Trace Element Movement in Soils: Influence of Soil Physical and Chemical Properties". Soil Sci., 122:350-359.

Kramer, P.J. and T.T. Kozlowski, 1979, Physiology of Woody Plants. Academic Press, New York, $811 \mathrm{pp}$.

Lamoreaux, R.J. and W.R. Chaney, 1977, "Growth and Water Movement in Silver Maple Seedlings Affected by Cadmium". Journal of Envirommental Quality, 6 (2):201-205.

LeBlanc, D.C. and C. Loehle, 1990, Dendroecological Analysis of Effect of Contaminated Groundwater on Tree Growth. WSRC-RP-90-552, Westinghouse Savannah River Co., Savannnah River Lab, Aiken, SC 29808.

Leckie, J.O. and J.A Davis, 1979, "Aqueous Environmental Chemistry of Copper". in J.O. Nriagu (ed), Copper in the Environment. Wiley, New York. 
Loehle, C. and J. Gladden, 1988, Preliminary Assessment of Tree Mortality Near F-and H-Area Seepage Basins. DPST-88-260. E.I. du Pont de Nemours and Company, Savannah River Laboratory, Aiken, SC.

Looney, B.B., J.C. Corey, and G.T. Wright, 1988, Sampling and Analysis of Surface Water in the vicinity of the F-and H-Area Seepage Basins. DPST-88-229. E.I. du Pont de Nemours and Company, Savannah River Laboratory, Aiken, SC.

Lower, M.W., 1987, Comprehensive Cooling Water Study, Vol. II Water Quality, DT-1739-2. E.I. du Pont de Nemours and Company, Savannah River Laboratory, Aiken SC.

Lumis, G.P., G. Hofstra, and R. Hall, 1973, "Sensitivity of Roadside Trees and Shrubs to Aerial Drift of Deicing Salt". Hortscience, Vol, 8(6):475-477.

Mackey, Jr., H.E., 1988, Initial Evaluation of Photographic Data of F-and H-Area Seepage Basin Outcrops. DPST-88-314. E.I. du Pont de Nemours and Company, Savannah River Laboratory, Aiken, SC.

McCabe, Jr., G.J., J.D. Mclaughlin, and R.A. Miller, 1985, Thornwaite Continuous Monthly Water Budget: a Computer Program in BASIC for Microcomputers. Louisiana Office of State Climatology.

McLeod, K.W., and D.L. Dawson, 1980, "Increased Cesium Uptake by Water Tupelo Under Inundated Conditions". Health Physics, 39:809-812.

Mitchell, C.D. and T.A. Fretz, 1977, "Cadmiu and Zinc Toxicity in White Pine, Red Maple, and Norway Spruce". Journal of American Society of Horticultural Science, 102 (1): 81 -84.

Mitsch, W.J., and J.G. Gosselink, 1986, Wetlands. Van Nostrand Reinhold, New York.

Panshin, A.J., and C. deZeeuw, 1980, Textbook of Wood Technology, McGraw-Hill Book Company, New York, 772 pp.

Penfound, 1934, "Comparative Structure of the Wood in the 'Knees', Swollen Bases, and Normal Trunks of the Tupelo Gum (Nyssa aquatica)". Amer J Bot, 21:623-631.

Ponnaperumma, F.N., 1972, ":The Chemistry of Submerged Soils". Adv. Agron., 24:29-98.

Pickering, W.F., 1979, "Copper Retention by Soil/Sediment Compounds". in J.O. Nriagu (ed), Copper in the Environment, Wiley, New York.

Radwan, M.A., J.S. Shumway, and D.S. DeBell, 1979, "Effects of Manganese and ManganeseNitrogen Applications on Growth and Nutrition of Douglas Fir Seedlings". USDA Forest Service Research Paper, PNW-265, 12 p. Pacific Northwest Forest and Range Experiment Station, Portland, Oregon.

Redman, F.H. and W.H. Patrick, 1965, Effects of Submergence on Several Biological and Chemical Soil Parameters. Louisiana State University Agricultural Experiment Station Bulletin No. 592.

Reichert, S.O., 1958, Geology and Hydrology for Disposal of Radioactive Wastes to Ground at the Savannah River Plant. USAEC Report DP-341. E.I. du Pont de Nemours and Co., Savannah River Laboratory, Aiken, SC. 
Reichert, S.O., 1968, "Geology Plays an Important Role in Radioactive Waste Management". Mining Engineering, 20(9):98-103.

Reichert, S.O. and J.W. Fenimore, 1962, "Lithology and Hydrology of Radioactive WasteDisposal Sites, Savannah River Plant, South Carolina". in Engineering Geology Case Histories, No. 1-5. Geological Society of America, Inc., NY, No.5, p 295-311.

Richardson, C.J., 1985, "Mechanisms Controlling Phosphorus Retention Capacity in Freshwater Wetlands". Science, 228:1424-1427.

Richardson, C.J., P.A. Straub, K.C. Ewel, and H.T. Odum, 1983, "Sulfate Enriched Water Effects on a Floodplain Forest". Env. Mgmt., Vol.67, No.4.

Roy, A.K., A. Sharma, and G. Talikder, 1988, "Sorne Aspects of Aluminum Toxicity in Plants". The Botanical Review, 54(2):145-178.

Schroeder, D.C. and G.F. Lee, 1975, "Potential Transformations of Chromium in Natural Waters". Water Air and Soil Pollution, 4:355-365.

Shainberg, I. and J. Letey, 1984, "Response of Soils to Sodic and Saline Conditions". Hilgardia, 52:1-5.5.

Shortle, W.C. and K.T Smith, 1988, "Aluminum-Induced Calcium Deficiency Syndrome in Declining Red Spruce". Science, 240:1017-1018.

Siple, G.E., 1967, Geology and Ground Water of the Savannah River Plant and Vicinity, South Carolina. U.S. Geological Survey Water Supply Paper 1841, 113 p.

Sopper. W.E. and S.N. Kerr, 1980,' Cadmium in Forest Ecosystems". in Cadmitum in the Environment -Part I: Ecological Cycling. J.O. Nriagu ed. John Wiley and Sons, New York, pp 655-667.

Sposito, G., 1981, "Trace Metals in Contaminated Waters". Envir. Sci. Tech., 15:396-403.

Stone, E.L. and V.R. Timmer, 1975, "On the Copper Content of Some Northern Conifers". Canadian Journal of Botany, 53:1453-1456.

Temple, P.J., S.N. Linzon, and M.L. Smith, 1978, "Fluorine and Boron Effects on Vegetation in the Vicinity of a Fiberglass Plant". Water, Air, and Soil Pollution, 10:163-174.

Teskey, R.O. and T.M. Hinckley, 1977a, "Impact of Water Level Changes on Woody Riparian and Wetland Communities". Vol.I. Plant and Soil Responses, FWS/OBS-77/59, U.S. Fish and Wildlife Service, U.S. Dept. of Interior, Washington, D.C.

Teskey, R.O. and T.M. Hinckley, 1977b, "Impact of Water Level Changes on Woody Riparian and Wetland Communities". Vol.II. Southern Forest Region, FWS/OBS-77/59, U.S. Fish and Wildlife Service, U.S. Dept. of Interior, Washington, D.C.

Thomas, W.A., 1975, "Cobalt Accumulation and Circulation by Blackgum Trees". Forest Science, 21:222-226.

Thorthwaite, C.W. and J.R. Mather, 1957, "Instructions and Tables for Computing Potential Evapotranspiration and the Water Balance". Publications in Climatology, Vol. X, No. 3. 
Thornton, F.C., M. Schaedle, and D.J. Raynal, 1986, "Effect of Aluminum on the Growth of Sugar Maple in Solution Culture". Canadian Journal of Forest Research, 16:892-896.

Thornton, F.C., M. Schaedle, and D.J. Raynal, 1987, "Effects of Aluminum on Red Spruce Seedlings in Solution Culture". Environmental and Experimental Botany, 27 (4):489-498.

Thorton, I., 1979, "Copper in Solls and Sediments. in J.O. Nriagu (ed)". Copper in the Environment, Wiley, New York.

Tusneem M.E. and Patrick, 1971, "Nitrogen Transformations in Waterlogged Soils". Louisiana State University Agricultural Experiment Station Bulletin No. 592.

Van Cleemput, O. and W.H. Patrick, 1974, "Nitrate and Nitrate Reduction in Flooded GammaIrradiated Soil Under Controlled pH and Redox Potential Conditions". Soil Biol. Biocihem., 6:85-88.

Van Hook, R.I., D.W. Johnson, and B.P. Spalding, 1981, "Zinc Distribution and Cycling in Forest Ecosystems". in Zinc in the Environment. Part I: Ecological Cycling. ed. by J.O. Nriagu. John Wiley and Sons, Inc., New York, pp 419-437.

Williams, J.B. and J.E. Pinder III, 1989, Groundwater Flow and Storm Runoff in a Southeastern Coastal Plain Stream. Draft report to E.I. du Pont de Nemours Company, Savannah River Plant, Aiken, SC. 


\section{APPENDIX A - SOILS DATA}

Soils data from MetaTRACE, Inc. (13715 Rider Trail Norh, Earth City, MO 63045) and Duke University Wetiands Center.

The procedure followed was to perform three analyses on each soil sample: water extract, nitric acid total digest (for metals oniy), and $\mathrm{NH} 4 \mathrm{Cl}$ extraction for $\mathrm{Ca}, \mathrm{Mn}, \mathrm{K}, \mathrm{Na}$, and $\mathrm{A} 1$. Soils were collected in the spring of 1989 . Six composite samples were taken at each site. Each composite sample consisted of soil from a coring tube from the top 12 inches to 18 inches of soil for at least six subsamples spread over a 12 foot by 12 foot area. The composite samples were taken randomly dispersed over each site. Soils were air dried and shipped to MetaTrace, Inc. for analysis.

The procedure followed is outlined below:

\section{Water Ex ion}

- Create a soil-solution ratio of 1:1 (actual soil weight dependent on volume needed for analysis)

- Use high purity $\mathrm{H}_{2} \mathrm{O}$ (nanopure or equivalent) in polyethylene or Teflon ${ }^{\mathrm{TM}}$ labware properly acid washed for trace metal analysis

- Equilibrare soil:water mixtures for $24 \mathrm{hrs}$ on an end-over-end mixer

- Eiter sample through $0.45 \mathrm{~mm}$ acid washed polycarbonate filter

- Split sampie into unacidiried ( $\mathrm{pH}$, electrical conductivity and 7 anions) and acidified (ultrex $\mathrm{HNO}_{3}$-fo: cation, trace metal and $\mathrm{Al}$ analyses) subsamples

- Measure pH, and EC on unacidified subsample immediately following extraction

- Measure $\mathrm{NO}_{3}-\mathrm{Cl}^{-}$, and $\mathrm{SO}_{4}=$ on samples using inductivity coupled plasma within one week of extraction (store all samples at $4 \mathrm{deg} \mathrm{C}$ )

- Measure Ni, Cd, Zn, As, Ant, Be, Cr, Cu, Pb, Hg, Se, Ag, Tl, Ca, Mg, K, Na, and Al on acidified subsamples by furnace AA or inductively coupled plasma

\section{Total Metals}

Digest $1-10 \mathrm{~g}$ aliquots of sediments with nitric acid in Teflon ${ }^{\text {TM }}$ bombs, following the methods described in "Procedures for Handling and Chemical Analyses of Sediment and Water Samples," EPA/CM-81-1.

\section{3. $\mathrm{NH}_{4} \mathrm{Cl}$ Extractions}

Sediment samples, 1:5 soil:solution rati extracted three times with $1 \mathrm{M} \mathrm{NH} 4 \mathrm{Cl}$ (gold label) according to the following:

- All sediments weighed out into acid washed polyethylene labware 
- $1 \mathrm{M} \mathrm{NH} 4 \mathrm{Cl}$ is added, the samples are placed on an end-over-end shaker for 30 minutes, centrifuged at $2500 \mathrm{rpm}$ until clear and the supernatant passed through an acid washed polycarbonate filter. This procedure is repeated two more times with the filtered "upernatants being combined.

- Analy 2 the $\mathrm{NH} 4 \mathrm{Cl}$ extracts for $\mathrm{Ca}, \mathrm{Mg}, \mathrm{K}, \mathrm{Na}$, and $\mathrm{Al}$ by appropriate analytical methods (AA or ICP)

\section{MetaTRACE Analyses Report}

\section{Water Extraction:}

Al! samples clogged the $0.45 \mathrm{~mm}$ polycarbonate filter following the 24 hour extraction. To remedy this, the extraction was repeated using a second aliquot of sample, and the modification of centrifuging each sample at approximately $2500 \mathrm{rpm}$ for 15 minutes prior to filtration.

Many of the samples absorbed water to the extent that there was insufficient volume to perform all requested analyses. In these cases, more water was added, the sample was mixed well manually, centrifuged again, and filtered. All filtered supernatants were pooled in one container. These samples required a third centrifugation.

Problems-MetaTRACE sample No. 00454 had insufficient sample for the re-extraction and only 210 grams were available. No. 00466 was extracted using 250 grams but yielded only $70 \mathrm{~mL}$ of water upon extraction. Since more samples were available, this $70 \mathrm{~mL}$ was diluted to $300 \mathrm{~mL}$ and analyzed further.

All data for ICAP metals, anions, $\mathrm{pH}$, and conductivity were corrected for the mass taken. The values are given in micrograms per gram $(\mathrm{mg} / \mathrm{g})$ and represent the concentration of the respective analyates per unit mass of material extracted.

\section{$\mathrm{NH}_{4} \mathrm{Cl}$ Extraction}

Each sample was digested per specifications using a $20 \mathrm{~g}$ aliquot and $100 \mathrm{ml}$ of $1 \mathrm{M} \mathrm{NH} 4 \mathrm{Cl}$. Data are reported in $\mathrm{mg} / \mathrm{L}$. any value less than $5 \mathrm{x}$ the Instrument Detection Limit was considered not detected (see Table 1). 
Table 1

\section{Instrument Detection Limits for ICAP}

WATER

SOIL

$\begin{array}{clc}\text { Element } & \begin{array}{l}\text { IDL in } \\ \text { mg/iter }\end{array} & \begin{array}{c}5 \times \mathrm{IDL} \\ \text { in mg/iter }\end{array} \\ \mathrm{Al} & 0.030 & 0.150 \\ \mathrm{As} & 0.040 & 0.200 \\ \mathrm{Be} & 0.001 & 0.005 \\ \mathrm{Cd} & 0.004 & 0.020 \\ \mathrm{Cr} & 0.005 & 0.025 \\ \mathrm{Cu} & 0.010 & 0.050 \\ \mathrm{Ni} & 0.020 & 0.100 \\ \mathrm{~Pb} & 0.060 & 0.300 \\ \mathrm{Sb} & 0.050 & 0.250 \\ \mathrm{Tl} & 0.060 & 0.300 \\ \mathrm{Zn} & 0.004 & 0.020 \\ \mathrm{Se} & 0.035 & 0.175 \\ \mathrm{Ca} & 0.020 & 0.100 \\ \mathrm{Mg} & 0.004 & 0.020 \\ \mathrm{~K} & 2.000 & 10.000 \\ \mathrm{Na} & 0.040 & 0.200 \\ \mathrm{Ag} & 0.005 & 0.025\end{array}$

$\mathrm{DL}$ in $\mathrm{mg} / \mathrm{gram}$

$\begin{array}{rr}6.0 & 30.0 \\ 8.0 & 40.0 \\ 0.2 & 1.0 \\ 0.8 & 4.0 \\ 1.0 & 5.0 \\ 2.0 & 10.0 \\ 4.0 & 20.0 \\ 12.0 & 60.0 \\ 10.0 & 50.0 \\ 12.0 & 60.0 \\ 0.8 & 4.0 \\ 7.0 & 35.0 \\ 4.0 & 20.0 \\ 0.8 & 4.0 \\ 400.0 & 2000.0 \\ 8.0 & 40.0 \\ 1.0 & 5.0\end{array}$


Table 2

Samples Requiring a Dilution Other Than 1:1 for the Water Extraction Procedure Meta TRACE Alignot Size

ID Number in grams

$\begin{array}{lll}00450 & 250 & \text { Extracted } 3 \text { times with } 250 \mathrm{~mL} \text { each time } \\ 00452 & 250 & \text { Extracted } 3 \text { times with } 250 \mathrm{~mL} \text { each time } \\ 00455 & 250 & \text { Extracted } 3 \text { times with } 250 \mathrm{~mL} \text { each time } \\ 00454 & 210 & \text { Extracted once with } 250 \mathrm{~mL} \text { water } \\ 00466 & 250 & \begin{array}{l}\text { Extracted once with } 250 \mathrm{~mL} \text { water which yielded } \\ 70 \text { mL which was diluted to } 300 \text { mL. }\end{array}\end{array}$

All other samples were extracted to yield a dilution of 500 grams to $500 \mathrm{~mL}$, or 1:1 ratio. 

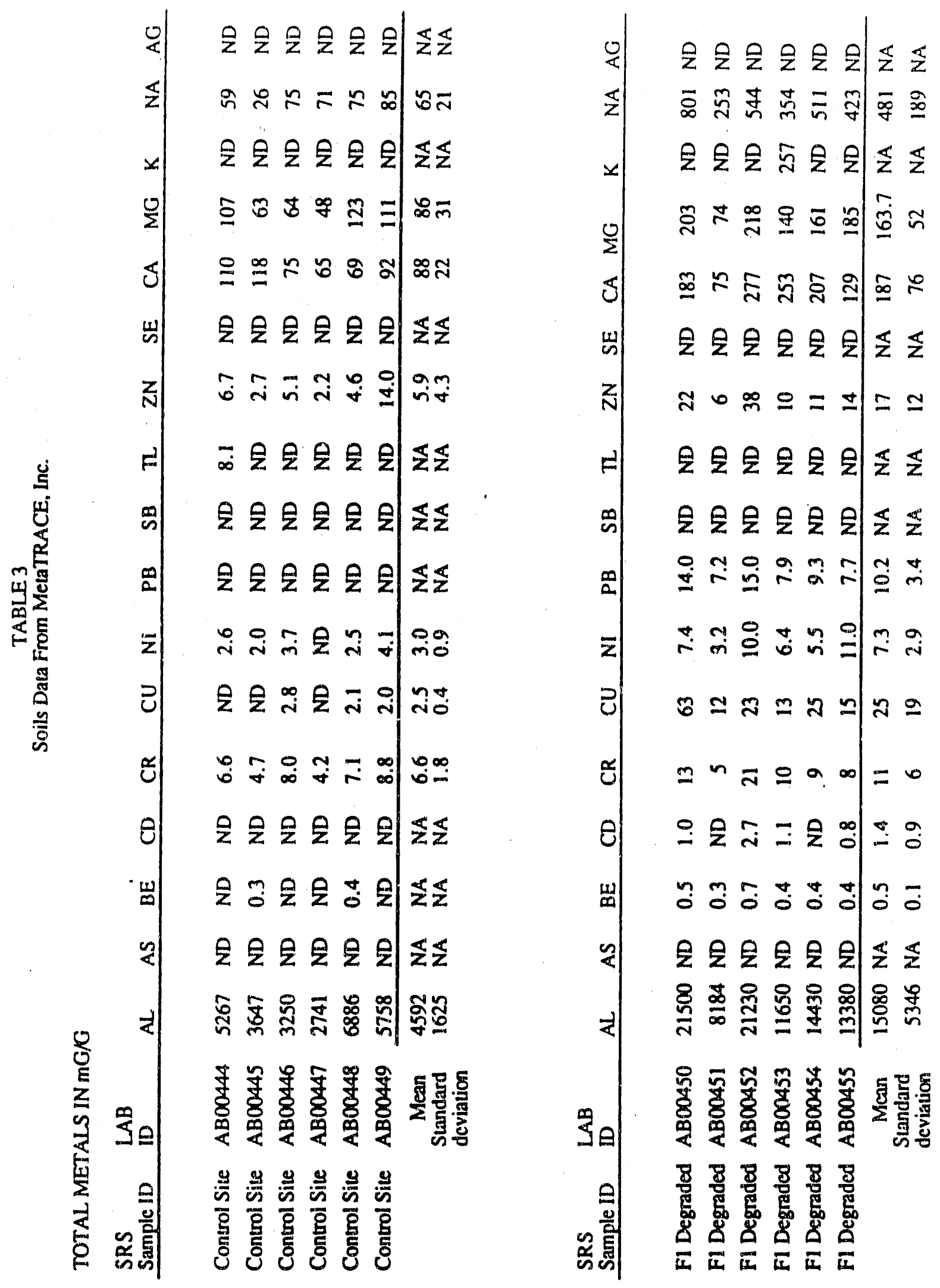

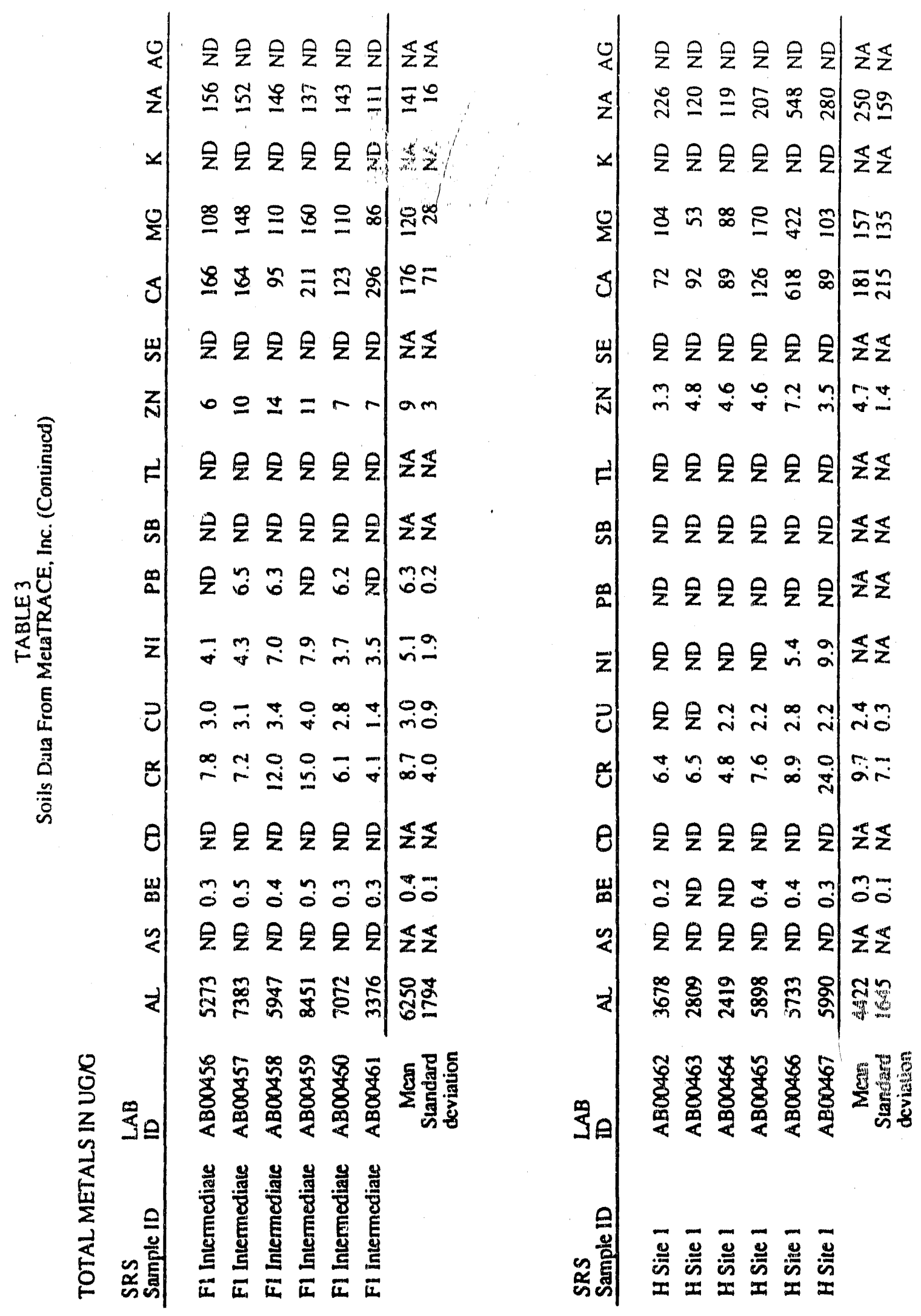
Table 4

Soils Data from MetaTRACE, Inc.

Water Extract $\mu \mathrm{g} / \mathrm{L}(\mathrm{EC}$ in $\mathrm{mmhos} / \mathrm{cm})$

\begin{tabular}{ccccccc} 
SRS & LAB & & & & \\
Sample ID & ID & PH & EC & CL & N03 & S04 \\
\hline Control Site & AB00444 & 4.37 & 161 & 3.7 & 41 & 16 \\
Control Site & AB00445 & 5.81 & 112 & 4.4 & 1.5 & 15 \\
Control Site & AB00446 & 6.44 & 156 & 2.3 & 6.6 & 25 \\
Control Site & AB00447 & 5.24 & 207 & 3.9 & 0.4 & 18 \\
Control Site & AB00448 & 5.80 & 105 & 4.0 & 15 & 9 \\
Control Site & AB00449 & 5.71 & 108 & 3.7 & 14 & 19 \\
\cline { 2 - 5 } & X & 5.56 & -142 & 3.7 & 13.1 & 17 \\
& S & 0.7 & 41 & 0.7 & 14.9 & 5
\end{tabular}

\begin{tabular}{ccccccc} 
SRS & LAB & \multicolumn{1}{c}{ C } & N03 & \multicolumn{1}{c}{ S04 } \\
Sample ID & ID & PH & EC & \multicolumn{1}{c}{ CL } & \multicolumn{1}{c}{ N03 } \\
\hline F1 Degraded & AB00450 & 4.21 & 957 & 3.7 & 486 & 4.8 \\
F1 Degraded & AB00451 & 6.70 & 342 & 8.1 & 95 & 21 \\
F1 Degraded & AB00452 & 4.51 & 674 & 6.9 & 1231 & 8.7 \\
F1 Degraded & AB00453 & 6.44 & 188 & 10.8 & 140 & 56 \\
F1 Degraded & AB00454 & 4.73 & 559 & 3.0 & 355 & 7.8 \\
F1 Degrarled & AB00455 & 6.15 & 390 & 10.9 & 410 & 51 \\
& X & 5.46 & -518 & 7.2 & 453 & 25 \\
& S & 1.09 & 274 & 3.4 & 411 & 23
\end{tabular}

\begin{tabular}{|c|c|c|c|c|c|c|}
\hline $\begin{array}{c}\text { SRS } \\
\text { Sample ID } \\
\end{array}$ & $\begin{array}{c}\text { LAB } \\
\text { ID }\end{array}$ & $\mathrm{PH}$ & $\mathrm{EC}$ & $C$ & No3 & SO4 \\
\hline Fl Intermediate & $A B 00456$ & 5.90 & 179 & 5.4 & 63 & 18.4 \\
\hline F1 Intermediate & $\mathrm{AB} 00457$ & 2.76 & 965 & 5.0 & 263 & 11.3 \\
\hline F1 Intermediate & $\mathrm{AB} 00458$ & 4.61 & 393 & 5.4 & 162 & 9.7 \\
\hline Fl Intermediate & AB00459 & 5.81 & 186 & 3.0 & 85 & 7.7 \\
\hline F1 Intermediate & $A B 00460$ & 4.54 & 611 & 5.6 & 284 & 5.2 \\
\hline F1 Intermediate & $\mathrm{AB} 00461$ & 2.10 & 5302 & 1.3 & 1680 & 3.8 \\
\hline & $X$ & 4.29 & 1273 & 4.3 & $\begin{array}{l}423 \\
623\end{array}$ & 9.4 \\
\hline
\end{tabular}

\begin{tabular}{ccccccc} 
SRS & LAB & & & & & \\
Sample ID & ID & PH & EC & C & N03 & S04 \\
\hline HSite 1 & AB00462 & 6.91 & 148 & 1.5 & 3.2 & 18 \\
H Site 1 & AB00463 & 3.69 & 270 & 2.9 & 86 & 8.9 \\
H Site 1 & AB00464 & 6.51 & 81 & 2.6 & 0.5 & 4.9 \\
H Site 1 & AB00465 & 6.22 & 147 & 3.7 & 34 & 8.2 \\
H Site 1 & AB00466 & 7.19 & 516 & 5.6 & 2.6 & 28 \\
H Site 1 & AB00467 & 4.75 & 259 & 1.4 & 120 & 3.1 \\
& X & 5.89 & -237 & 3.0 & 41.1 & 13.5 \\
& S & 1.37 & 155 & 1.6 & 50.7 & 8.4
\end{tabular}



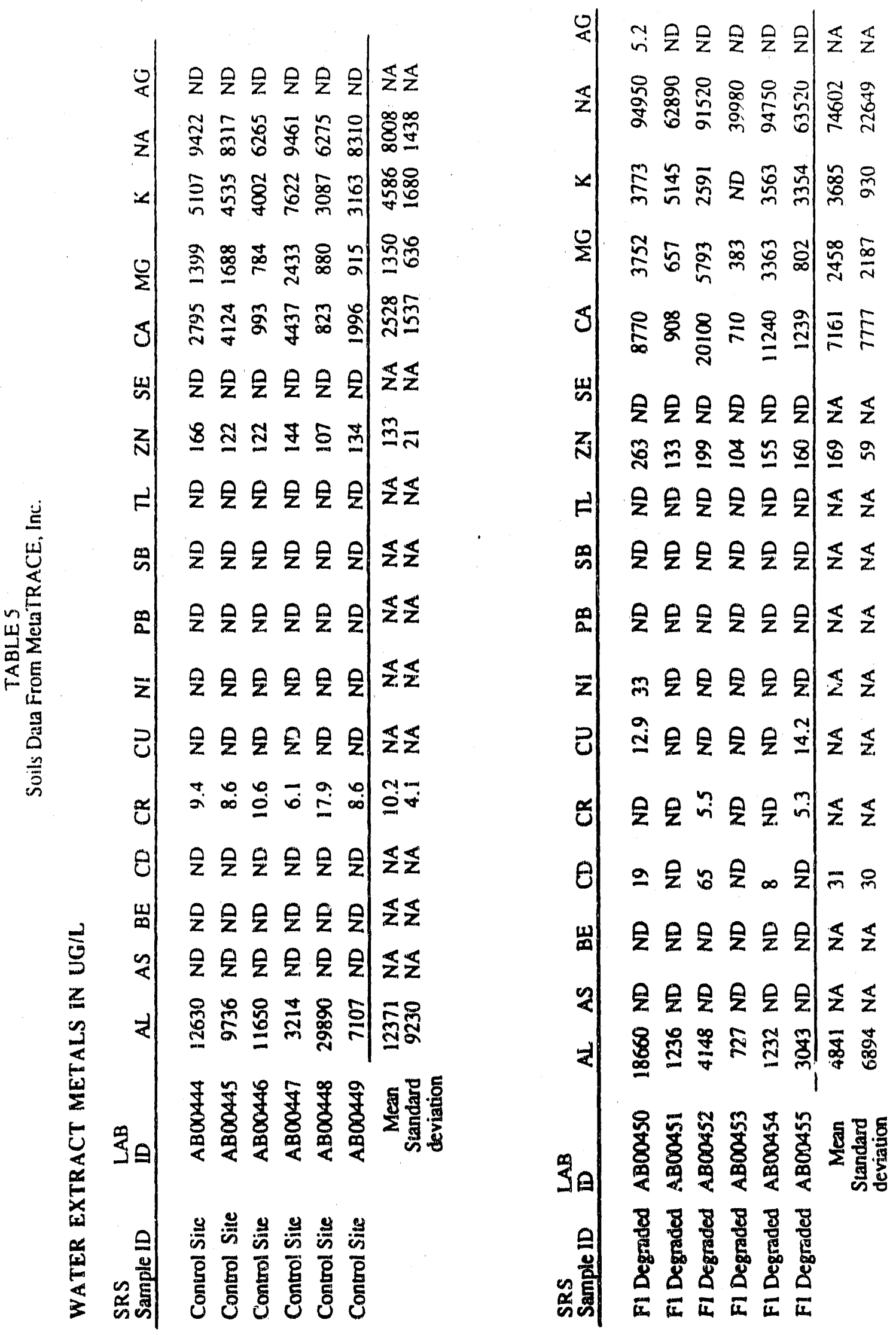

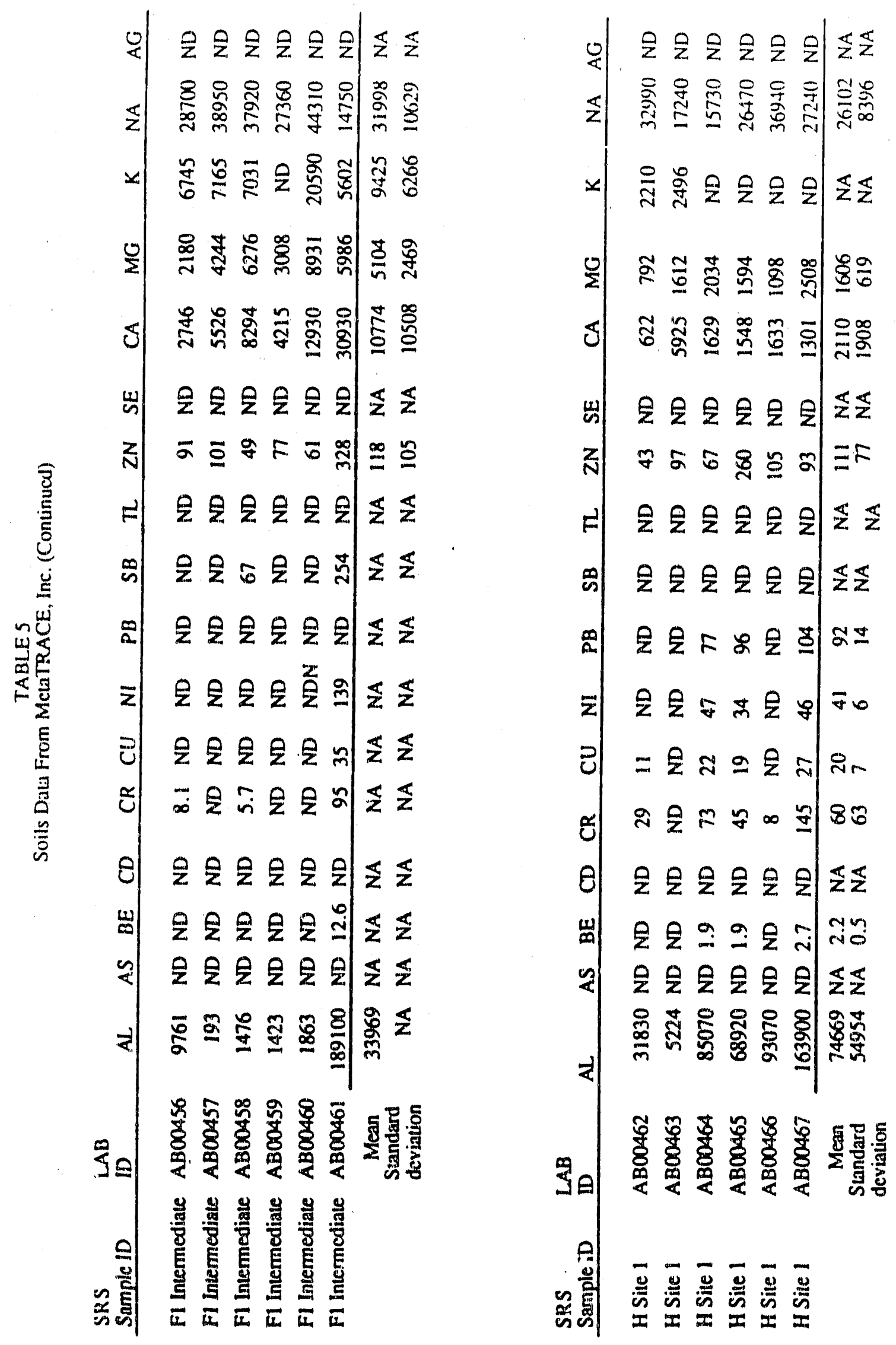


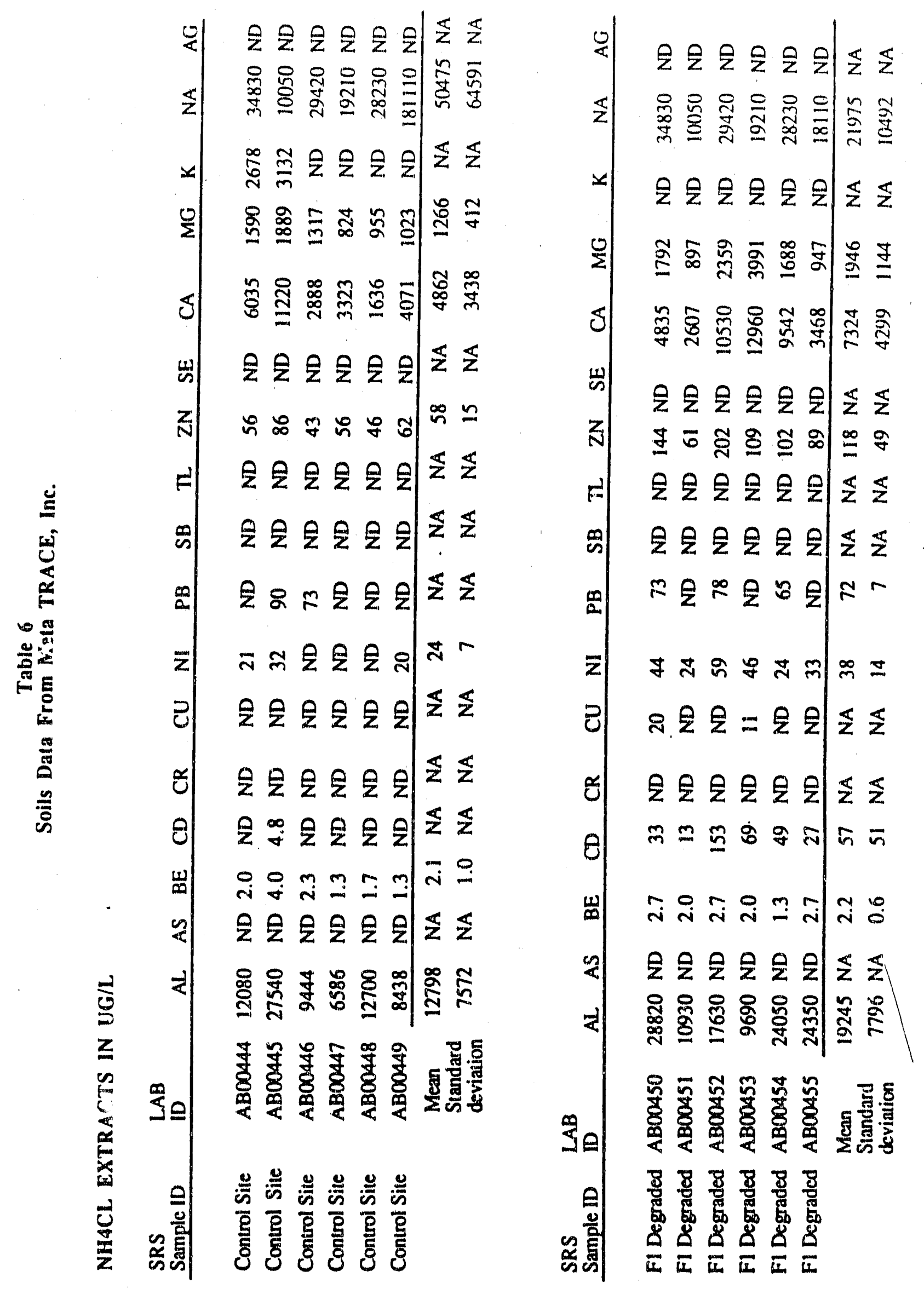




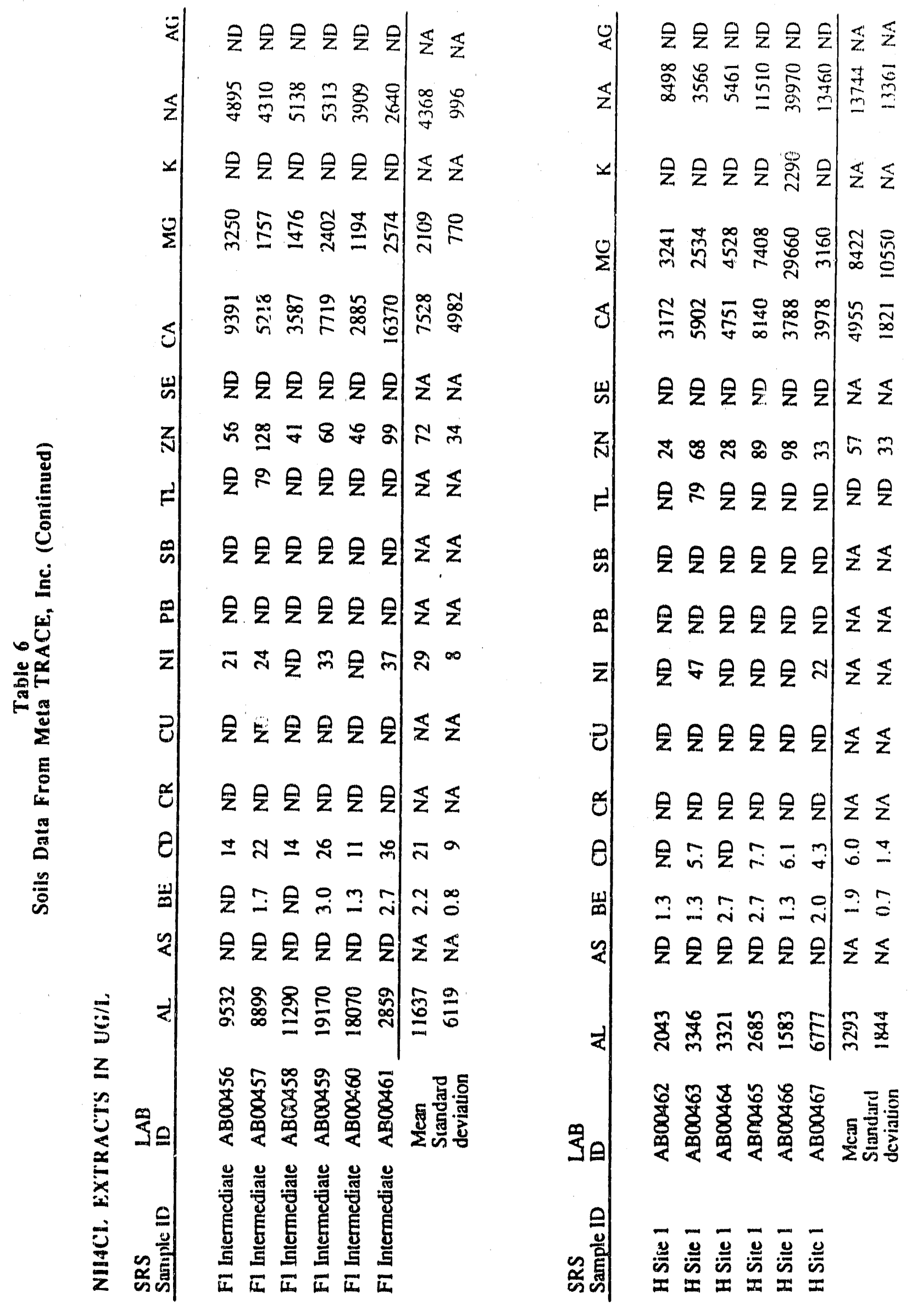


Soil extracts ( $4 \mathrm{~g}$ soil extracted with 40 milliliters of $1 \mathrm{M} \mathrm{NH} 4 \mathrm{C} 1$ ) in micrograms per gram performed at Duke Wetlands Center. Aluminum oxalate was extracted to determine amoiphous aluminum content of soils following Richardson (1985).

\begin{tabular}{|c|c|c|c|c|c|c|c|}
\hline Sample \# & Label & $\mathrm{Ca}$ & $M g$ & $\mathbf{K}$ & $\mathbf{N a}$ & Al & Al oxalate \\
\hline $\begin{array}{l}14 \\
21 \\
25\end{array}$ & $\begin{array}{l}\text { CONT1 } \\
\text { CONT2 } \\
\text { CONT3 }\end{array}$ & $\begin{array}{l}267 \\
422 \\
189\end{array}$ & $\begin{array}{l}138 \\
125 \\
108\end{array}$ & $\begin{array}{l}208 \\
164 \\
228\end{array}$ & $\begin{array}{l}35 \\
29 \\
54\end{array}$ & $\begin{array}{l}358 \\
317 \\
446\end{array}$ & $\begin{array}{l}2444 \\
3399 \\
5107\end{array}$ \\
\hline $\begin{array}{l}22 \\
15 \\
16\end{array}$ & $\begin{array}{l}\text { F CONM1 } \\
\text { F CONM2 } \\
\text { F CONM3 }\end{array}$ & $\begin{array}{l}4077 \\
4901 \\
142\end{array}$ & $\begin{array}{c}1500 \\
1742 \\
46\end{array}$ & $\begin{array}{r}98 \\
224 \\
93\end{array}$ & $\begin{array}{l}982 \\
981 \\
407\end{array}$ & $\begin{array}{l}<20 \\
<2.0 \\
219\end{array}$ & $\begin{array}{l}18390 \\
14750 \\
20646\end{array}$ \\
\hline $\begin{array}{l}18 \mathrm{~A} \\
18 \mathrm{~B} \\
24 \mathrm{~A} \\
24 \mathrm{~B} \\
20 \mathrm{~A} \\
20 \mathrm{~B}\end{array}$ & $\begin{array}{ll}\text { F } & \text { INT1 } \\
\text { F } & \text { INT1 } \\
\text { F } & \text { INT2 } \\
\text { F } & \text { INT2 } \\
\text { F } & \text { INT3 } \\
\text { F } & \text { INT3 }\end{array}$ & $\begin{array}{r}328 \\
462 \\
99 \\
106 \\
258 \\
307\end{array}$ & $\begin{array}{r}74 \\
105 \\
32 \\
31 \\
62 \\
69\end{array}$ & $\begin{array}{l}63 \\
46 \\
31 \\
33 \\
43 \\
42\end{array}$ & $\begin{array}{r}78 \\
97 \\
107 \\
117 \\
149 \\
169\end{array}$ & $\begin{array}{r}46 \\
53 \\
86 \\
131 \\
175 \\
83\end{array}$ & $\begin{array}{l}4736 \\
4861 \\
7408 \\
6423 \\
7887 \\
7701\end{array}$ \\
\hline $\begin{array}{l}17 \\
23 \\
19 \mathrm{~A} \\
19 \mathrm{~B}\end{array}$ & $\begin{array}{l}\text { H AREA1 } \\
\text { H AREA2 } \\
\text { H AREA3 } \\
\text { H AREA3 }\end{array}$ & $\begin{array}{r}517 \\
789 \\
118 \\
84\end{array}$ & $\begin{array}{r}59 \\
105 \\
75 \\
91\end{array}$ & $\begin{array}{l}66 \\
59 \\
21 \\
29\end{array}$ & $\begin{array}{r}57 \\
18 \\
143 \\
170\end{array}$ & $\begin{array}{l}<20 \\
<20 \\
<20 \\
<20\end{array}$ & $\begin{array}{l}556 \\
513 \\
265 \\
315\end{array}$ \\
\hline
\end{tabular}


Table 8

Foliage and root digests (approx, $0.4 \mathrm{~g}$ samples digested by Hach Digesdahl Method).

\begin{tabular}{|c|c|c|c|c|c|c|c|c|}
\hline Sample \# & Label & & $\% \mathbf{N}$ & $\% \mathbf{P}$ & $\begin{array}{l}\mu \mathrm{g} / \mathrm{g} \\
\mathrm{NA}\end{array}$ & $\begin{array}{l}\mu \mathrm{g} / \mathrm{g} \\
\mathrm{MN}\end{array}$ & ${ }_{A \mathbf{L}}^{\mu \mathrm{g} / \mathrm{g}}$ & $\underset{\mathrm{CD}}{\mu \mathrm{g} / \mathrm{g}}$ \\
\hline 1 & F INT3 & $\mathrm{L}$ & 1.28 & 0.080 & 461 & 4016 & 310 & 4.05 \\
\hline 2 & CONT1 & $\bar{L}$ & 1.19 & 0.106 & 280 & 955 & 344 & 0.20 \\
\hline 3 & H AREA3 & $\mathbf{R}$ & 0.69 & 0.087 & 1663 & 664 & 11063 & 0.09 \\
\hline 4 & F INT2 & $\mathbf{R}$ & 1.74 & 0.046 & 6176 & 352 & 16750 & 1.91 \\
\hline 5 & F INT3 & $\mathbf{R}$ & 1.22 & 0.060 & 1544 & 351 & 23820 & 4.02 \\
\hline 6 & H AREAI & $\mathbf{R}$ & 0.53 & 0.070 & 1673 & 135 & 15524 & 0.01 \\
\hline 7 & F CONM1 & $\mathbf{R}$ & 0.99 & 0.063 & 2071 & 1562 & 15866 & 3.37 \\
\hline 8 & CONT2 & $\mathbf{R}$ & $0.9 ?$ & 0.075 & 490 & 299 & 26702 & 0.13 \\
\hline 9 & F CONM2 & r & 1.46 & 0.086 & 2504 & 4030 & 28222 & 7.64 \\
\hline 10 & CONT3 & $\mathbf{R}$ & 0.56 & 0.083 & 484 & 300 & 7257 & 0.15 \\
\hline 11 & H AREA2 & $\mathbf{R}$ & 0.98 & 0.076 & 678 & 669 & 15630 & 0.13 \\
\hline 12 & F CONM3 & $\ddot{R}$ & 0.83 & 0.065 & 7737 & 114 & 30141 & 0.55 \\
\hline 13 & F INT1 & $\mathbf{R}$ & 1.66 & 0.066 & 2335 & 1959 & 13797 & 14.27 \\
\hline 26 & CONT1 & $\mathbf{R}$ & 0.71 & 0.048 & 467 & 274 & 8042 & 0.11 \\
\hline 27 & F CONM1 & $\mathbf{L}$ & 1.12 & 0.060 & 691 & 2985 & 120 & 0.25 \\
\hline 28 & F INT2 & L & 1.55 & 0.086 & 394 & 5178 & 403 & 0.56 \\
\hline 29 & H AREA3 & $\bar{L}$ & 1.47 & 0.097 & 370 & 386 & 151 & 0.14 \\
\hline 30 & F CONM2 & L. & 0.91 & 0.047 & 314 & 1323 & 112 & 0.46 \\
\hline 31 & CONT3 & $\bar{L}$ & 1.59 & 0.230 & 312 & 1788 & 436 & 0.09 \\
\hline 32 & CONT2 & L & 1.32 & 0.083 & 261 & 936 & 264 & 0.35 \\
\hline 33 & F INT1 & L & 1.29 & 0.070 & 299 & 2966 & 352 & 0.66 \\
\hline 34 & H CONM1 & L & 1.00 & 0.074 & 407 & 746 & 265 & 0.16 \\
\hline
\end{tabular}



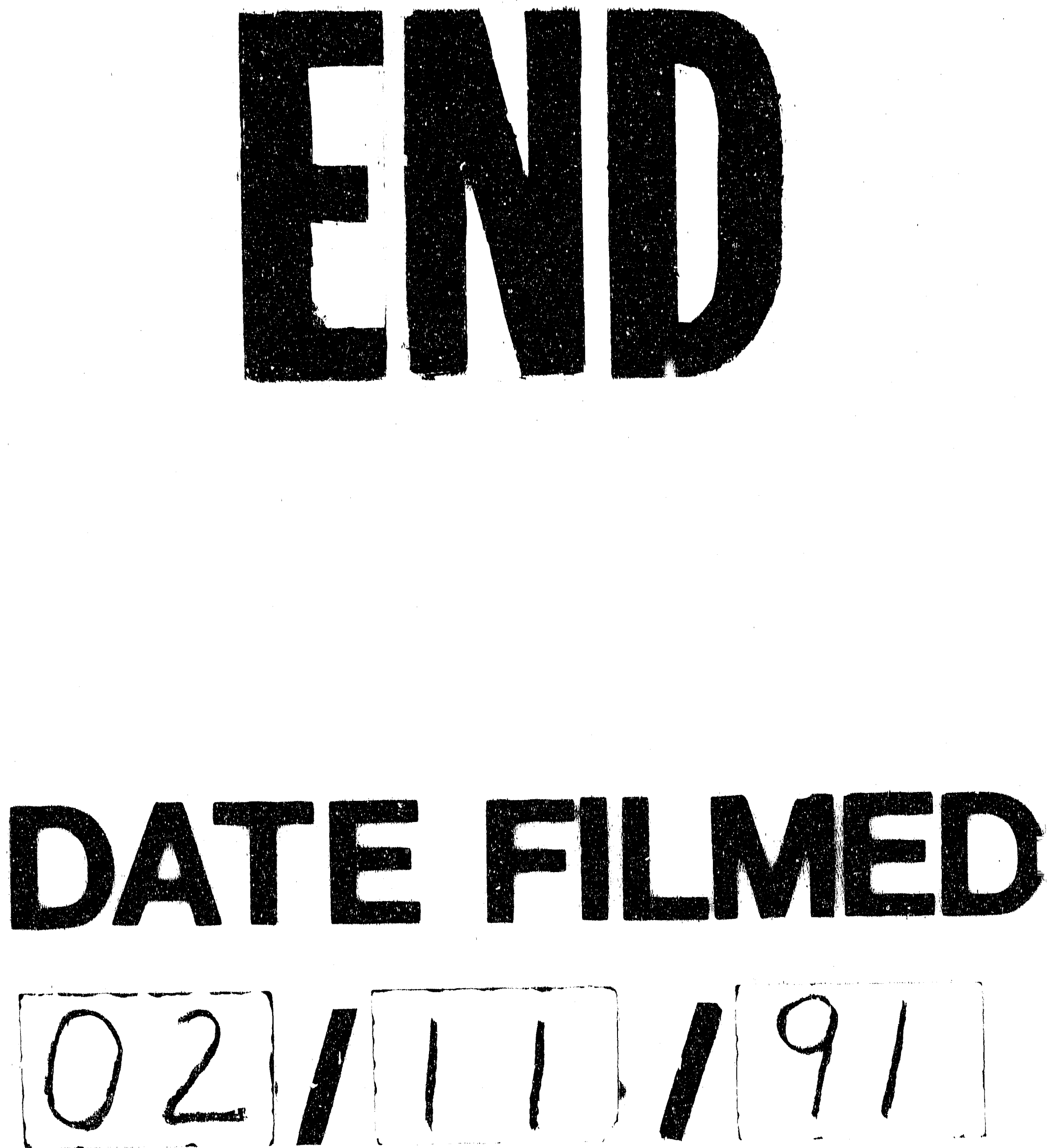

$$
\text { 站 }
$$

